\title{
BOCSKAY GYÖRGY KALLIGRÁFUS ANTIKVA BETŰS SÍREMLÉKFELIRATAI
}

\author{
ALL'ANTICA REPREZENTÁCIÓ I. FERDINÁND BÉCSI UDVARÁBAN
}

Bocskay György (†1575) harminc évig állt a bécsi udvar szolgálatában, ahol a Magyar Királyi Kancellárián kezdetben írnok, majd magyar udvari titkár, illetve tanácsos volt. ${ }^{1}$ Emellett elismert kalligráfusként foglalkoztatták, egyedi írásmintakönyveket és okleveleket ${ }^{2}$ díszített a mindenkori uralkodó és más megrendelők számára. Nem volt szokatlan, hogy az „ars scribendi” müvelőinek mesterségbeli tudását építészeti jellegü feliratokhoz is igénybe vették. ${ }^{3}$ Bocskay nevéhez szintén köthetők ilyen müvek, amelyek két kiemelkedő jelentőségü síremlékre, I. Miksa császár innsbrucki, illetve Nádasdy Tamás nádor és felesége, Kanizsay Orsolya lékai tumbájára kerültek. Az alábbiakban az antikva betüs síremlékfeliratok keletkezéstörténetét mutatjuk be.

\section{Antikés all'antica feliratos emlékek az udvar környezetében}

I. Ferdinánd császári ambícióit már uralkodása kezdetén fontosnak tartotta antikizáló müalkotások formájában megörökíteni. ${ }^{4}$ A 16 . század közepén Bécsben az ókori régiségek és all'antica müalkotások, egyúttal a római eredetü antikva betüs feliratok újabb felértékelődésének lehetünk tanúi. Mindez I. Ferdinándnak a császári cím megszerzésére irányuló és végül sikert hozó törekvéseivel függött össze. Bár bátyja, V. Károly 1556-os lemondása után ténylegesen csak 1558-tól birtokolta a címet, utódlásának kérdése már az 1540-es évek végétől napirenden volt. Végül a német protestáns fejedelmek felkelése és az azt lezáró passaui szerződés (1552) következtében lett bizonyos, hogy a cím a Habsburgok osztrák ágán öröklődik majd tovább. ${ }^{5}$ Ezért a bécsi - még csak leendő császári udvarban az all'antica udvari reprezentáció egyre intenzívebbé vált.

Bécs az 1530-as évek első felében lett I. Ferdinánd uralkodói központja. ${ }^{6}$ Ezt követően indult meg a Hofburg középkori magjának az átépítése, amely az 1560-as évekig zajlott német és itáliai mesterek, többek között Francisco da Pozzo és Pietro Ferrabosco közreműködésével. ${ }^{7}$ A felújított rezidenciában stukkókkal, faborítással és falfestményekkel díszített fogadó- és lakótereket hoztak létre, némelyiket kazettás famennyezettel borították. A legfrissebb reneszánsz építészeti formák alkalmazása egy oszlopokkal tagolt, reprezentatív lépcsőház kialakításában is megmutatkozott, amelynél a források szerint I. Ferdinánd nem a német építőmesterek, hanem az itáliai Pozzo elképzeléséhez ragaszkodott. ${ }^{8}$ A Hofburg egységes ablakokkal tagolt, új homlokzatot is kapott. A profilozott nyíláskereteket az Aranygyapjas-rendre utaló motívumok (András-keresztre helyezett kovakő és -vas) díszítették, amelyek a Habsburg-ház burgundiai örökségére és a kereszténység védelmére utaltak. ${ }^{9}$

A rezidencia új főbejárata, a Schweizertor szintén ekkor épült (1552-1553). Markánsan antikizáló architektúrája révén az azonos ablakok által tagolt külső homlokzat leghangsúlyosabb eleme lett (1-2. kép). I. Ferdinánd a kaput közvetlenül az említett passaui szerződés aláírása után emeltette, így a mű beteljesült császári ambícióit hirdette. ${ }^{10}$

A Schweizertor Sebastiano Serlio építészeti traktátusának a hatását mutatja. Az ókori építészet vitruviusi elveit elsősorban az itáliai szerző müvei közvetítették a bécsi udvarba. A legismertebb IV. könyv első német nyelvü kiadását a flamand 


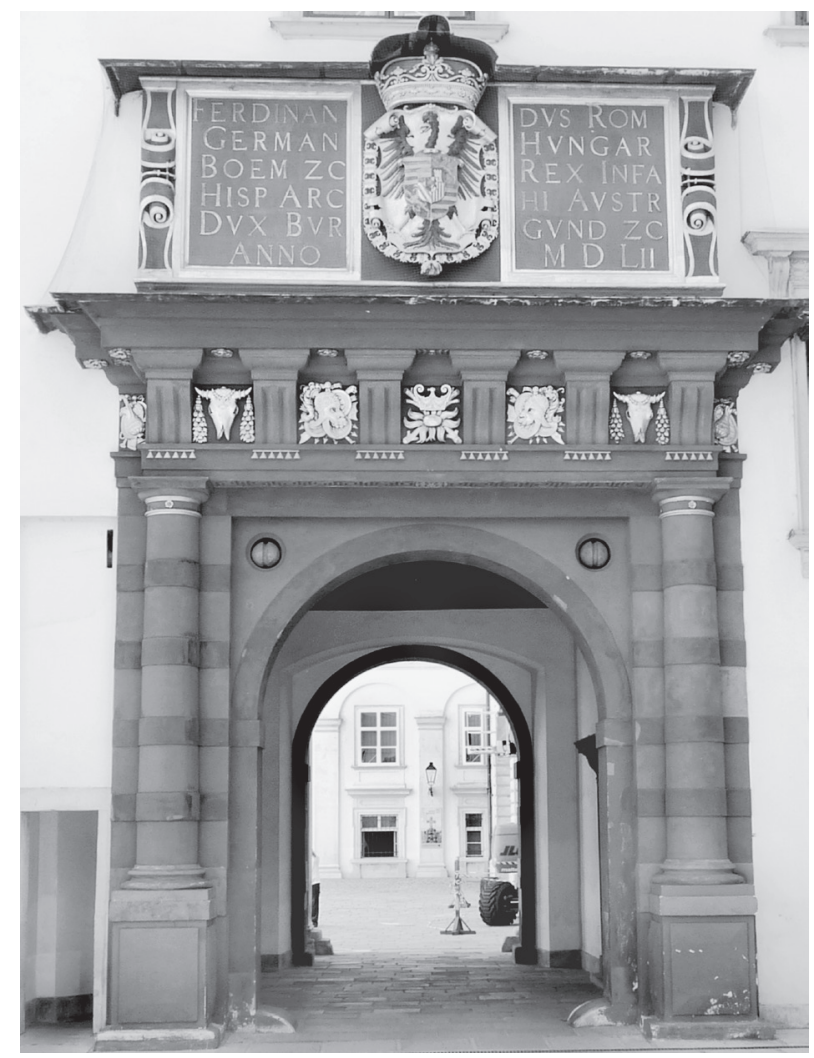

1. A Schweizertor külső homlokzata (A szerző felvétele, 2011)

Pieter Coecke van Aelst már 1542-ben I. Ferdinándnak ajánlotta (Die gemaynen Reglen von der Architectur uber die funf Manieren der Gebeu... Antwerpen 1542). ${ }^{11}$ Az uralkodó tisztában volt a vitruviusi alapfogalmakkal, például egy levelében "oszlopos homlokzatról”, „architrávról” és "frízről" tett említést. ${ }^{12}$ Maga a Schweizertor az ókori római diadalíveket imitálja. Mindkét homlokzatát rusztikázott dór féloszlopok, illetve pilaszterek keretezik, amely oszloprendet Serlio Jupiterrel, Marssal és Herkulessel feleltetett meg. ${ }^{13}$ A párkányzat középső metopéiba - az új ablakok díszítéséhez hasonlóan - az Aranygyapjas-rend szimbólumai kerültek. Ezt a külső oldalon all'antica trófeumok és bukranionok, az udvari oldalon pedig groteszk maszkok, Jupiter villámai és a szintén Jupiterre, egyúttal pedig a császárságra utaló sas motívuma egészítette ki. Az attika részletformái egy konkrét ókori római építményről, a Forum Boarium diadalívéről származtak, amelyet a Serlio-traktátus IV. könyve a dór oszloprend ismertetése kapcsán illusztráció formájában is közölt. ${ }^{14}$

A kapu tervezője Pietro Ferrabosco lehetett, akit az udvar ezt követően elsősorban építészként foglalkoztatott. Bár a rá vonatkozó forrásokban csak az szerepel, hogy a festésben vett részt, 1553-ban a címer és a feliratos táblák hátterének színezéséért,

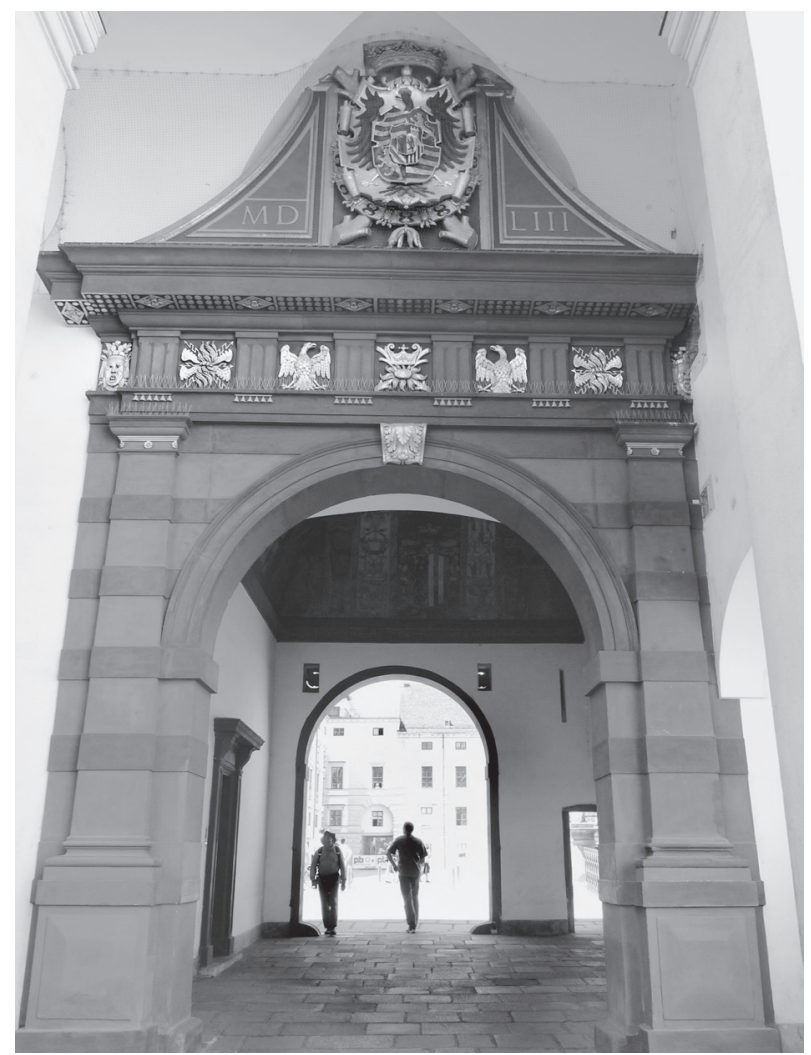

2. A Schweizertor belső homlokzata (A szerző felvétele, 2011)

valamint az átjáró mennyezetére került, groteszk címeres dekoráció elkészítéséért kapott fizetést. ${ }^{15}$

A kapu attikáján monumentális antikizáló feliratok olvashatók, amelyek a címer két oldalára, keretezett tabulákba kerültek (1-2. kép). A latin szövegek a külső oldalon Ferdinánd római királyi címével kezdődő titulatúráját és az építés kezdetét, a belső oldalon pedig a befejezés időpontját tartalmazzák. A tűzaranyozott fémbetük készítője Valthin Kraus, egy helyi mester volt. ${ }^{16}$ A klasszikus antikva kapitálisokat profilozott arany keretbe foglalták, a tabulák alapszíne pedig vörös lehetett. ${ }^{17}$ Ily módon a Schweizertor nagyméretü antikva betüi a római császárkorban oly népszerü, vörös márványra bronzberakással készült monumentális feliratokat idézték fel. A térségben ennek első reprezentatív megoldásai Mátyás király budai palotájában és az esztergomi Bakócz-kápolnában jelentek meg. Az eljárást az egykorú itáliai reneszánsz emlékek mellett főként az augustusi aranykorral foglalkozó antik auktorok közvetítették az Alpoktól északra. ${ }^{18}$ Ezen a ponton azt is ki kell emelnünk, hogy a legfrissebb restaurátori vizsgálatok ${ }^{19}$ alapján a kapu eredetileg nem polikróm, hanem egységesen kékesszürke volt, és csupán a fenti zónájában voltak színes applikációk (a triglifsor arany figurális részei, valamint az attikán a színes, aranyozott címer és a színes tabu- 


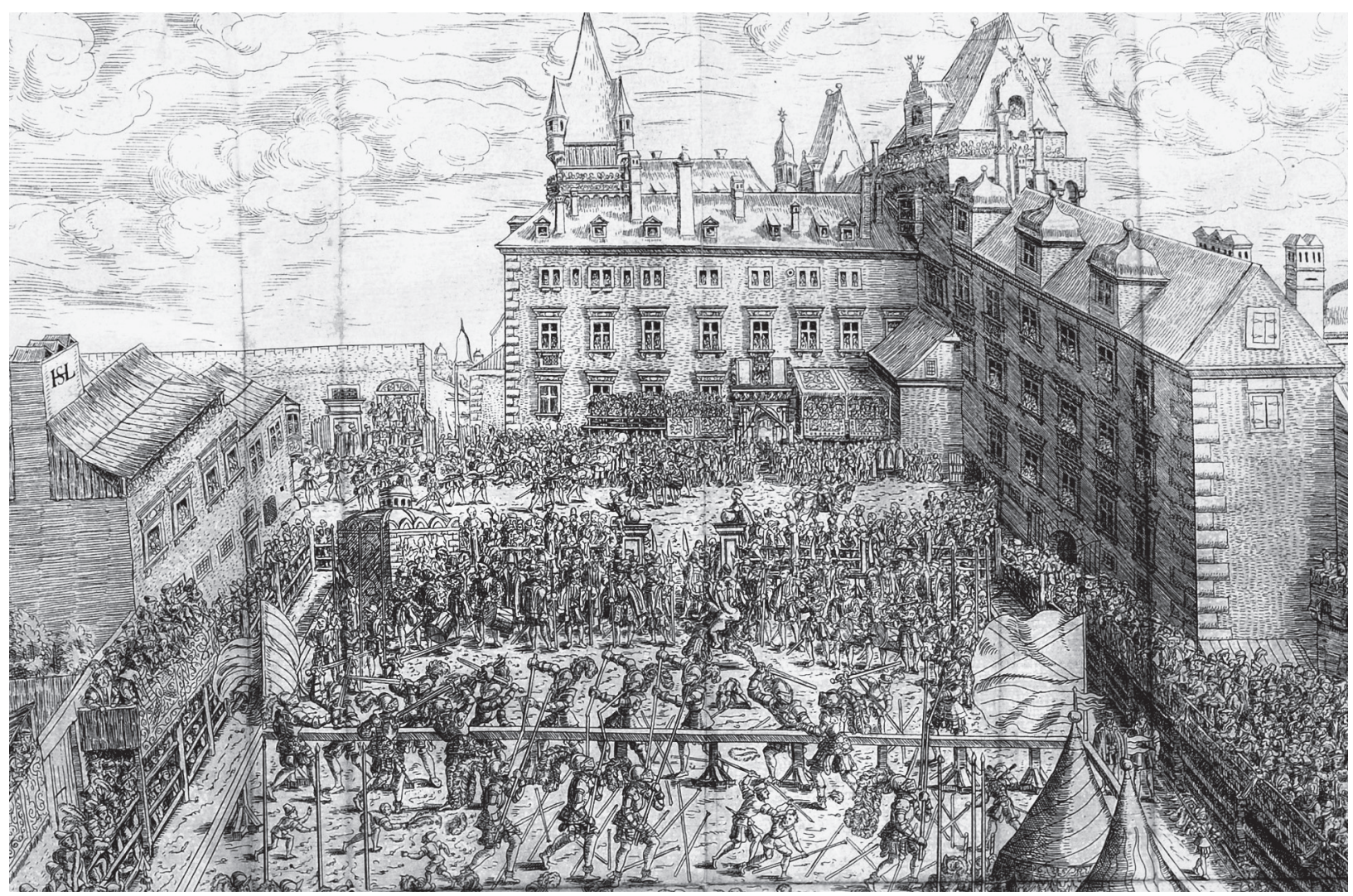

3. Hans Sebald Lautensack: Lovagi torna a Hofburg elött (részlet) (Hans Francolin: Rerum praeclare gestarum... Viennae 1560, XXII. után, Országos Széchényi Könyotár, Budapest, App. Hung. 2548 [1])

lákban az arany antikva fémbetűk). Így ezek az elemek, köztük a monumentális antikizáló feliratok az architektúra egészén belül külön hangsúlyt kaptak.

A Schweizertor révén tehát az uralkodói rezidencia homlokzatára egy római diadalív került. Rendszerint az előtte kialakított térségen ${ }^{20}$ rendezték a lovagi tornákat, amelyek alkalmával az új diadalkapu all'antica ünnepi dekorációvá lényegült át. Például itt tartották a Wiener Turnier (1560. május 24 . - június $24 .{ }^{21}$ ) két látványos viadalát is. ${ }^{22}$ Ezekhez nem épültek jelentősebb efemer dekorációk, a legelőkelőbb nézők (I. Ferdinánd, V. Albert bajor választófejedelem és családja) tribünjét pedig a szimbolikus diadalív mellé helyezték el (3. kép).

Miután I. Ferdinánd elnyerte a császári címet, az udvari ünnepségeken az antikizáló dramaturgiai elemek és efemer dekorációk használata egyre gyakoribbá vált. ${ }^{23}$ Ennek előzményei I. Miksa és V. Károly császár idejére nyúltak vissza. I. Miksa megbízásából az uralkodó emlékezetét („Gedechtnus”) ${ }^{24}$ fenntartani hivatott, nagyszabású metszetsorozatok születtek. Közülük mind a Diadalkapu, mind a Diadalmenet és Dürer Nagy diadalkocsija az ókori triumphusok eszköztárát vonultatta fel. ${ }^{25} \mathrm{~V}$. Károly alatt pedig már a római diadalmenetek rendkívül tudatos újjáélesztése zajlott. A császár és fia, II. Fü- löp tiszteletére Európában addig soha nem látott mennyiségü antikizáló triumphust tartottak (Itália, Német-római Birodalom, Németalföld, Spanyolország, Anglia, Franciaország). Ezek ünnepi dekorációi között az efemer diadalíveknek kiemelt szerep jutott. ${ }^{26} \mathrm{Az}$ első osztrák területen emelt ideiglenes diadalkapuk szintén V. Károly két bevonulása alkalmából készültek. ${ }^{27}$

Mindezek ismeretében nem meglepő, hogy mennyire hangsúlyosan jelent meg az imperiális jellegú diadalív-motívum azon a két triumphuson (Bécs 1558. ápr. 14. ${ }^{28}$ Prága 1558. nov. ${ }^{2}{ }^{29}$ ), amelyet az I. Ferdinánd császárrá válását jelző frankfurti ünnepségek ${ }^{30}$ alkalmából rendeztek. Bécsben az új uralkodó látványos bevonulását lezáró lovagi tornát az említett Schweizertor elötti térségen tartották, amelyet I. Ferdinánd és családja a rezidencia ablakából tekintett meg. ${ }^{31}$ A prágai triumphust a cseh helytartó, Ferdinánd főherceg rendezte apja számára. Ez alkalomból többek között egy Silenost és Bacchust formázó, bort lövellő kutat készítettek, és a menet egyes állomásain I. Ferdinándot az antikizáló kosztümbe öltözött kilenc múzsa köszöntötte. Az esemény alkalmából számos efemer diadalív is épült, amelyeket terjedelmes latin feliratokkal és allegorikus dekorációval láttak el. Közülük a főher- 
ceg által emeltetett, óriási méretű diadalkaput érdemes kiemelni. A beszámolók szerint a korinthoszi oszlopokkal tagolt építmény festése a márványt és bronzot imitálta. Nagyméretü, valószínúleg mozgó kolosszusokkal (Sámson, Gedeon), valamint I. Miksa és V. Károly csatáit ábrázoló „bronz"-reliefekkel, álló „,bronz” császárfigurákkal (I. Rudolf, III. Frigyes) és erényalakokkal (pl. Religio, Iustitia, Temperantia) díszítették, a kompozíció tetejére pedig a császári sas került. ${ }^{32}$

A következő all'antica jellegü udvari ünnepség a Miksa főherceg római királlyá koronázását követő bécsi triumphus volt (1563. ápr. $16 .{ }^{33}$ ), amellyel a császári trón leendő várományosát ünnepelték. Ezért a bevonuláson a diadalívnek ismét fontos szerep jutott. Az ünnepség dekorációit és szövegeit Wolfgang Lazius udvari humanista állította öszsze, aki a program magyarázatát nyomtatásban is megjelentette. ${ }^{34}$ Miksa három efemer diadalkapun keresztül vonult be a városba. A márványhatásúra festett építmények Melchior Lorich tervei alapján készültek: az osztrák tartományokat, a magyar és cseh korona országait, valamint a császári cím át-

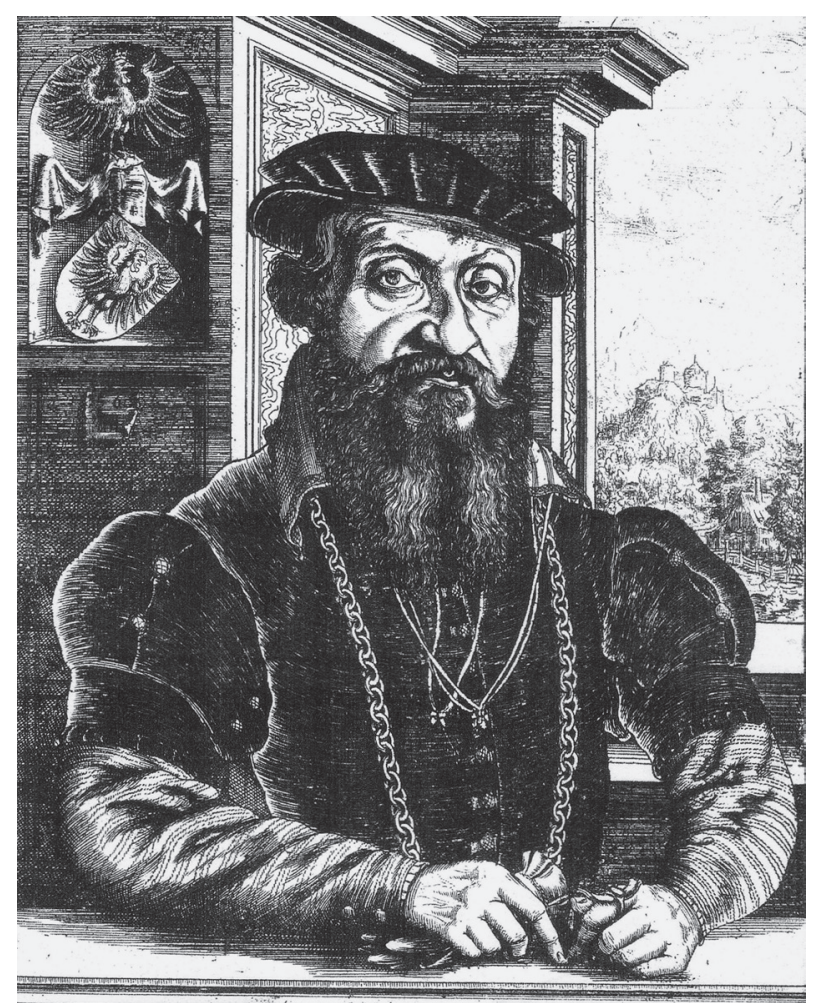

HERMES SCHALLAV'T'ZER+D , FERD I+ROM:IMP: CONSILIA: ET EIVSDEM AD FICIORVM PREF NATVS ANNOS LVII

4. Hans Sebald Lautensack: Hermes Schallauzer portréja (Wolfgang Lazius: Exempla... Viennae 1560, AI elött, ÖNB, Wien, Alt Prunk 19.Bb.28) adását jelenítették meg („Porta Austriaca”, „Porta Bohemica”, „Porta Romana”). A diadalkapukon a jelenlegi és a leendő császárt antikizáló utalásokkal megtűzdelt, hosszú latin feliratok dicsőítették. A kapuk részletgazdag ábrázolásait egy másik, német nyelvü beszámoló őrizte meg számunkra, amelybe Donat Hübschmann fametszetei kerültek. ${ }^{35}$

Néhány hónappal később, Miksa főherceg magyar királlyá koronázása alkalmából (Pozsony, 1563. szept..$^{36}$ ) szintén készültek efemer diadalívek. A két kapu tervezője a források szerint Pietro Ferrabosco volt, ${ }^{37}$ akit a Schweizertor kapcsán említettünk. A koronázás alkalmából egy illusztrált röplap jelent meg, amely Zsámboky János versét és Donat Hübschmann fametszetét tartalmazta. ${ }^{38} \mathrm{Az}$ ábrázoláson jól kivehetők a diadalkapuk, amelyeket a városba bevezető ideiglenes hajóhíd két végén emeltek. Ez alapján tudjuk, hogy mindkettő azonos díszítést kapott. Az egy nyílású építmények árkádívének a szegélye rusztikázott volt, az attikára pedig a császár, valamint a leendő király és királyné címere került. Egy olasz nyelvű beszámoló szerint a „nagyszerű kapuk úgy néztek ki, mintha márványból épültek volna". ${ }^{39}$

$\mathrm{Az}$ all'antica udvari reprezentáció további inspirálói voltak a század közepe táján alapított bécsi lapidáriumok és antikvitásgyüjtemények. 15591568 között került sor a Hofburg mellett található Stallburg kiépítésére, amelyet Miksa főherceg számára emeltek. ${ }^{40} \mathrm{~A}$ reprezentatív építmény háromszintes, árkádokkal tagolt belső udvara szintén Serlio hatását mutatta. Valószínúleg Jacopo Strada tervei alapján készült, kivitelezését pedig Pietro Ferrabosco vezette. A munkálatok során két feliratos római kori követ is találtak, amelyek Hermes Schallauzer ${ }^{41}$ saját lapidáriumába kerültek.

Schallauzer 1547 óta működött udvari építésfelügyelőként. A Hofburg átalakítása és Bécs erődítési munkálatai során felbukkanó római kori spoliumokról jelentésekben számolt be I. Ferdinándnak, aki átengedte neki a leleteket. Így a Graben sarkán álló házának a kertjében egy kisebb kőtárat alakíthatott ki belőlük. ${ }^{42} \mathrm{Az}$ ókori epigráfia iránti megnövekedett érdeklődés jellegzetes, immár uralkodói momentuma volt, hogy a császár a Stallburgnál talált kövek előkerülésének apropóján Schallauzert és unokaöccsét, az említett Laziust egy illusztrált ismertetés publikálásával bízta meg (Exempla aliquot S. vetustatis Rom... Bécs, 1560). ${ }^{43}$ Lazius a kötetben nagybátyja gyüjteményének hat, feliratos római kövét mutatta be. Élére a tulajdonos portréja került (4. kép), majd a leletek megtalálásának körülményeit tárgyaló bevezető után az egyes darabok epigráfiai elemzései következtek, amelyeket Hans Sebald Lautensack egy-egy egész lapos rézmetszete kísért (5. kép). 


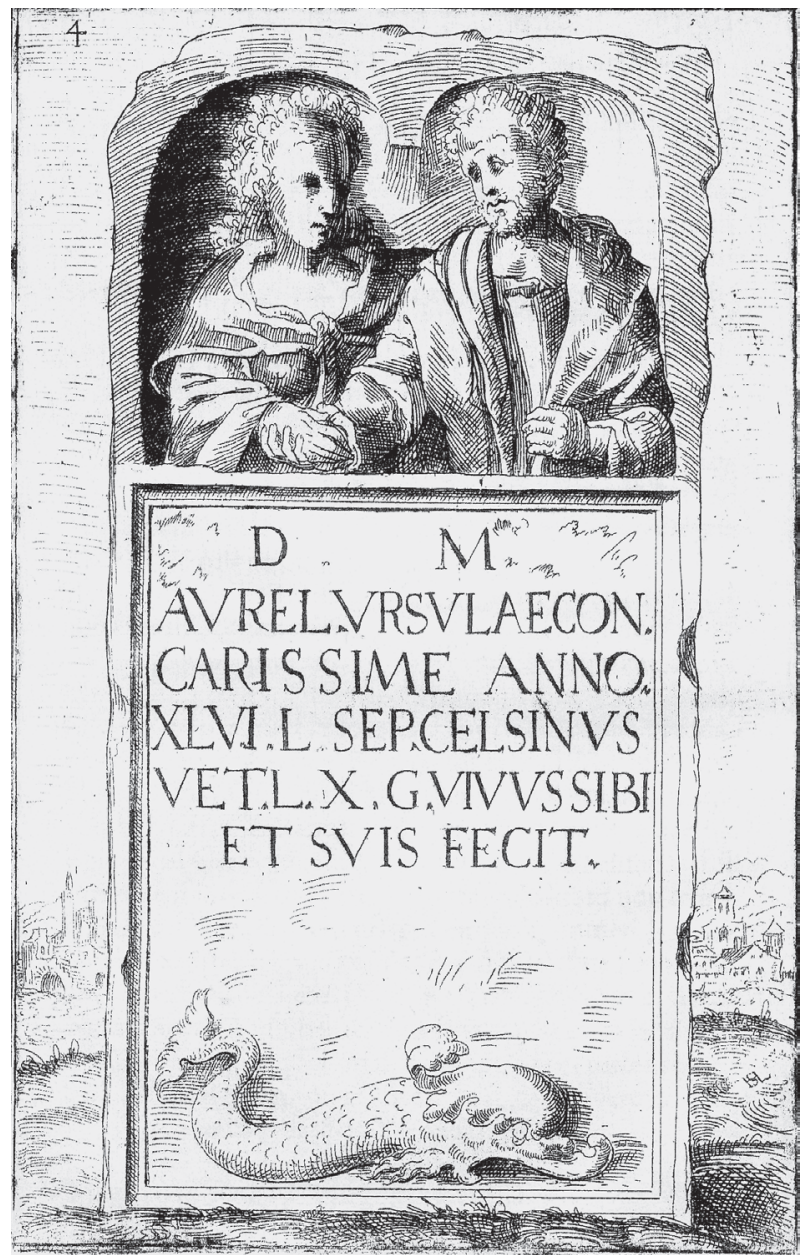

5. Hans Sebald Lautensack: Aurelia Ursula sírköve (Wolfgang Lazius: Exempla... Viennae 1560, DI-DII között, ÖNB, Wien, Alt Prunk 19.Bb.28)

A kötet szerzője, a tudós humanista, udvari orvos és történetíró Lazius ${ }^{44}$ (6. kép) is létrehozott Bécsben egy római lapidáriumot, amelyre Schallauzer példája ösztönözhette. ${ }^{45}$ A saját házában („Lazenhof") a római átriumok mintájára egy árkádos belső udvart alakított ki a leletek számára. Itt elhelyezett egy klasszikus latinsággal megírt alapítási feliratot is, ebből ismeretes, hogy a gyüjtemény 1548-ban már létezett. ${ }^{46}$ Lazius történetírói módszerének egyik fontos eleme volt az egykorú források felkutatása és használata, ${ }^{47}$ ezért gyűjteményének összeállításakor elsősorban a darabok forrásértékét tartotta szem előtt. Műveiben - például a Bécs város történetét először feldolgozó monográfiájában vagy a Bécs környéki római kori közigazgatást tárgyaló munkájában ${ }^{48}$ - előszeretettel hivatkozott a birtokában lévő ókori epigráfiai emlékekre.

Lazius antik feliratok iránti rajongása egy konkrét épület átalakításában is testet öltött. Az általa is elfogadottnak vélt hagyomány szerint Bécs legrégebbi - valójában először a 12 . században emlí- tett - templomát, a Graben melletti Peterskirchét Nagy Károly császár alapította. ${ }^{49} \mathrm{~A}$ templom azonban a 16. századra igen rossz állapotba került. Ezért Lazius irányításával és részben az ő, részben a város költségén 1554-1555-ben felújították..$^{50}$ Az épület történelmi múltjának megjelenítésében a felirat mint all'antica díszítőelem jutott szerephez. A falakat és az oszlopokat rendkívül hosszú, festett latin szövegek borították, amelyek Ausztria, ezen belül Bécs, valamint a templom történetét beszélték el. Az oltár melletti német szöveg pedig a Nagy Károly-féle alapításról és az I. Ferdinánd kegyelméből megvalósult Lazius-féle felújításról emlékezett meg. A minden bizonnyal Laziustól származó feliratok az egész belső tér dekorációját meghatározták. Ez azonban mára csupán leírásokból rekonstruálható, mivel a barokk idején a templom helyére lényegében egy új épület került. ${ }^{51}$

Az udvar környezetében keletkezett lapidáriumok mellett I. Ferdinándnak volt a legjelentősebb, római kövekből és egyéb leletekből, főként pénzérmékből álló antik gyüjteménye. Uralkodásának korai éveiben elsősorban az osztrák földön talált ókori leleteket igyekezett megszerezni. A Bécs közeli Carnuntum feltárása során például számos lelet került a birtokába. A későbbiekben már tudatos gyüjtésbe fogott és nem csupán a környező területekről, hanem Itáliából (Velence, Róma) és a távoli Konstantinápolyból is próbált minél több antik érméhez hozzájutni. ${ }^{52}$ Gyüjteményének egyik kiemelkedő darabja az 1502-ben Karintiában előkerült Magdalensbergi ifjú volt, amelyet 1551-ben a salzburgi székeskáptalanból szállíttatott Bécsbe. Mivel a szobor az első, Itálián kívül talált életnagyságú, egybeöntött ókori bronzlelet volt, így jelentősége az Alpokon túl a Belvederei Apollóéhoz volt fogható. ${ }^{53}$

Az uralkodói gyüjtemények elhelyezésére 1558ban egy külön szárnyat csatoltak a Hofburghoz. Az antikvitásoknak az udvari reprezentációban betöltött megnövekedett szerepét jelzi, hogy az új épület földszintjén, a díszkert felé nyitott árkádok alatt valószínúleg az ókori darabokat állították ki. ${ }^{54}$ Ez esetben az udvar tagjai számára az antikvitások folyamatosan hozzáférhetők voltak. A kerthez kapcsolódó architektúra kialakításában a korszak egyik legnagyobb hatású antik szoborgyưjteménye, a vatikáni Belvedere Cortile delle Statue-je lehetett a minta. ${ }^{55}$ Innen antikvitások is jutottak Bécsbe: 1561ben I. Cosimo Medici közvetítésével egy márvány Merkúr-szobor és egy oszlop került Miksa főherceg tulajdonába. ${ }^{56}$

I. Ferdinánd az antikvitásgyüjtemény kezelésével Wolfgang Laziust bízta meg, aki Jacopo Strada bécsi fellépéséig végezte feladatát. 1560-ban a csá- 
szár már az itáliai „Antiquario” számára állíttatott ki úti okmányokat, hogy Velencében antik portréfejeket vásároljon - bár a forrásból nem világos, hogy az uralkodó vagy saját maga számára. ${ }^{57}$

A beszerzésekről tudósító források mellett néhány egykorú inventárium is segíti a gyűjtemény rekonstrukcióját. Egészéről forrás egyelőre nem ismert, viszont a darabok tetemes részét kitevő, több mint 1500 darab, nagyrészt római császárkori pénzérméről több kéziratos inventárium, valamint egy nyomtatott mü is készült. Az első egy bővebb összeírás részlete volt (1544-47), ${ }^{58}$ amely szerint a numizmatikai kollekciót egy, a római konzulokkal és császárokkal kezdődő, majd Nagy Károlytól V. Károlyig ívelő sorozatként képzelték el. ${ }^{59}$ A gyűjtemény szimbolikus funkciója I. Ferdinánd 1554-es, utolsó végrendeletében is tetten érhető volt. Ebben a „,mindenféle régi pénzekkel és antikvitásokkal teli ládáit" külön megemlítette, és kifejezetten utódjára, a leendő császárra, II. Miksára hagyta. A pénzek anyagi értéke helyett azok tartalmi jelentőségét hangsúlyozta, és fiát annak változatlan formában való megőrzésével bízta meg. ${ }^{60}$

A numizmatikai kollekcióról két további kéziratos inventárium is fennmaradt. Az első Ferdinánd főherceg ambrasi, a második pedig II. Rudolf császár prágai gyưjteményéből került a mai őrzési helyére. A korábbi, papírra készült változat egy bővebb, antik érmékből álló listát közölt, az összes darabot anyag szerint, azon belül pedig kronologikusan tartalmazta (1547 után). ${ }^{61}$ A másik, valamivel későbbi kéziratot már egyértelmüen reprezentatív céllal állították össze $(1555-56){ }^{62}$ Erre utalt igényesebb kivitelezése - színes tintával pergamenre íródott -, továbbá koncentráltabb tartalma. Tulajdonképpen a korábbi katalógus római pénzekre koncentráló kivonata volt, ahol minden személyt csupán egy-egy darab képviselt: 89 konzuli, valamint Julius Caesarral kezdődően 135 császárkori darabot sorolt fel, kiegészítve V. Károly pénzeivel.

Lazius elsősorban numizmatikai tanácsadóként vett részt az antikvitásgyűjtemény rendezésében. Evvel függött össze, hogy 1554 körül a Schallauzerlapidárium katalógusának illusztrátora (4-5. kép), a nürnbergi Hans Sebald Lautensack őfelsége „,antikvitás-ábrázolójaként" (,antiquitet-abconterfetter") ${ }^{63}$ a bécsi udvar alkalmazásába került. Ekkori rajzaiból - amelyekből egy sem maradt meg - metszetek készültek volna, amelyekhez Lazius írta volna a nyomtatott katalógust. ${ }^{64} \mathrm{~A}$ tervezett münek végül csupán egy rövid része látott napvilágot (Commentariorvm Vetvstorvm Numismatvm... Bécs 1558).$^{65}$ Két Lautensack-féle rézmetszet került bele: Lazius auktorportréja (6. kép) és egy, az érmeket méretarányosan ábrázoló tábla (7. kép).

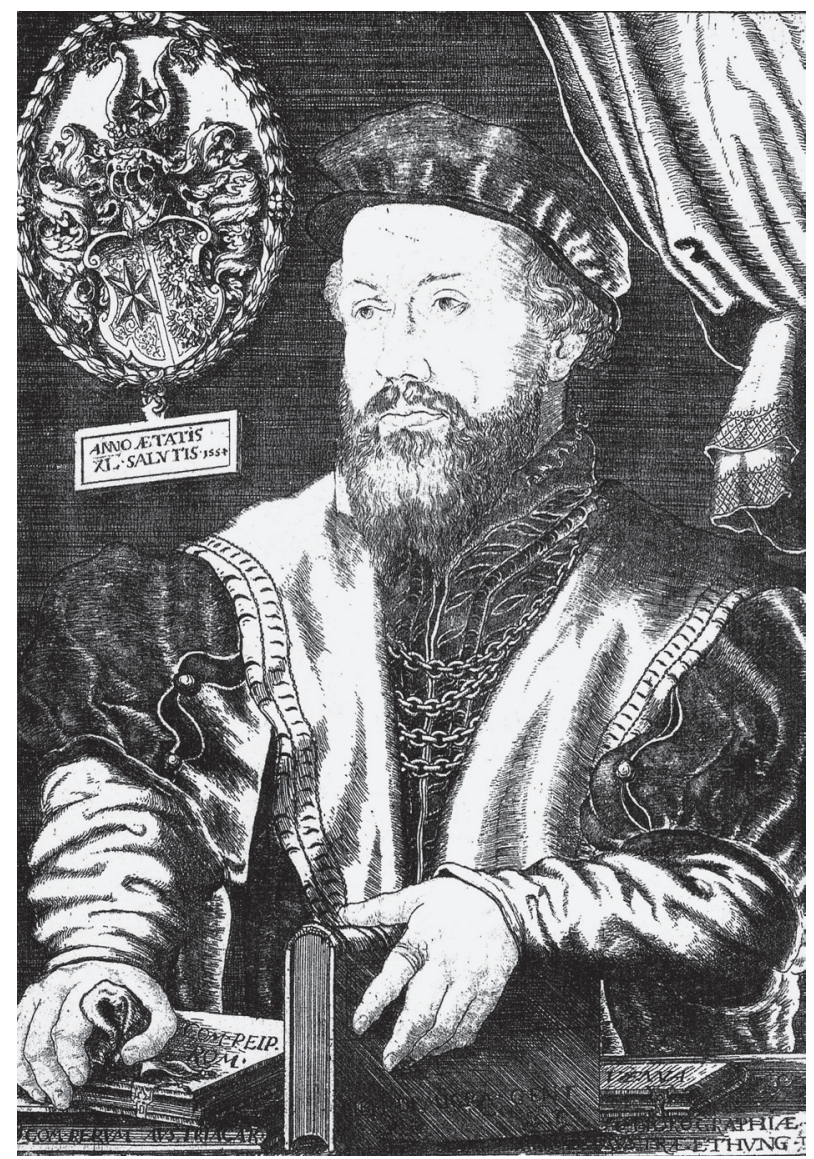

6. Hans Sebald Lautensack: Wolfgang Lazius portréja (Wolfgang Lazius: Commentariorum...

Viennae 1558, AIv, ÖNB, Wien, Alt Prunk 57.C.11)

A teljes változat megjelenése végül Jacopo Strada ${ }^{66}$ miatt hiúsult meg, aki 1558-ban - még Frankfurtból - szakmai szempontból lesújtó véleményt adott Lazius készülő katalógusáról. ${ }^{67} \mathrm{Az}$ itáliai szakértő pozícióját erősítette, hogy ekkor már több éve dolgozott egy átfogó antik numizmatikai katalógus kéziratán, amelynek a kivonata nyomtatásban is megjelent (Epitome thesauri antiquitatum... Lyon 1553). A mű legújabb kötetét (De Consularibus numismata ${ }^{68}$ ) I. Ferdinándnak ajánlotta, a folytatását pedig utódjának, Miksának ígérte.

Szerkesztóként nekik dedikálta a Rómában élő neves antikvitás-szakértő, Onofrio Panvinio két müvét is (Epitome Pontificum..., Fasti et Triumphi... Velence, 1557). ${ }^{69} \mathrm{Az}$ utóbbi egy mindössze néhány éve feltárt, rendkívül jelentős római epigráfiai lelet, a Fasti Capitolini ${ }^{70}$ egyik első nyomtatott kiadása volt. Panvinio a római tisztségviselők előkerült listáit tudományos igénnyel adta közre, a feliratokhoz az említett személyek pénzeinek az illusztrációi járultak. A névsor folytatódott a középkoron át egészen V. Károlyig, ezért Strada eredetileg neki ajánlotta a művet, és csak miután I. Ferdinándé 


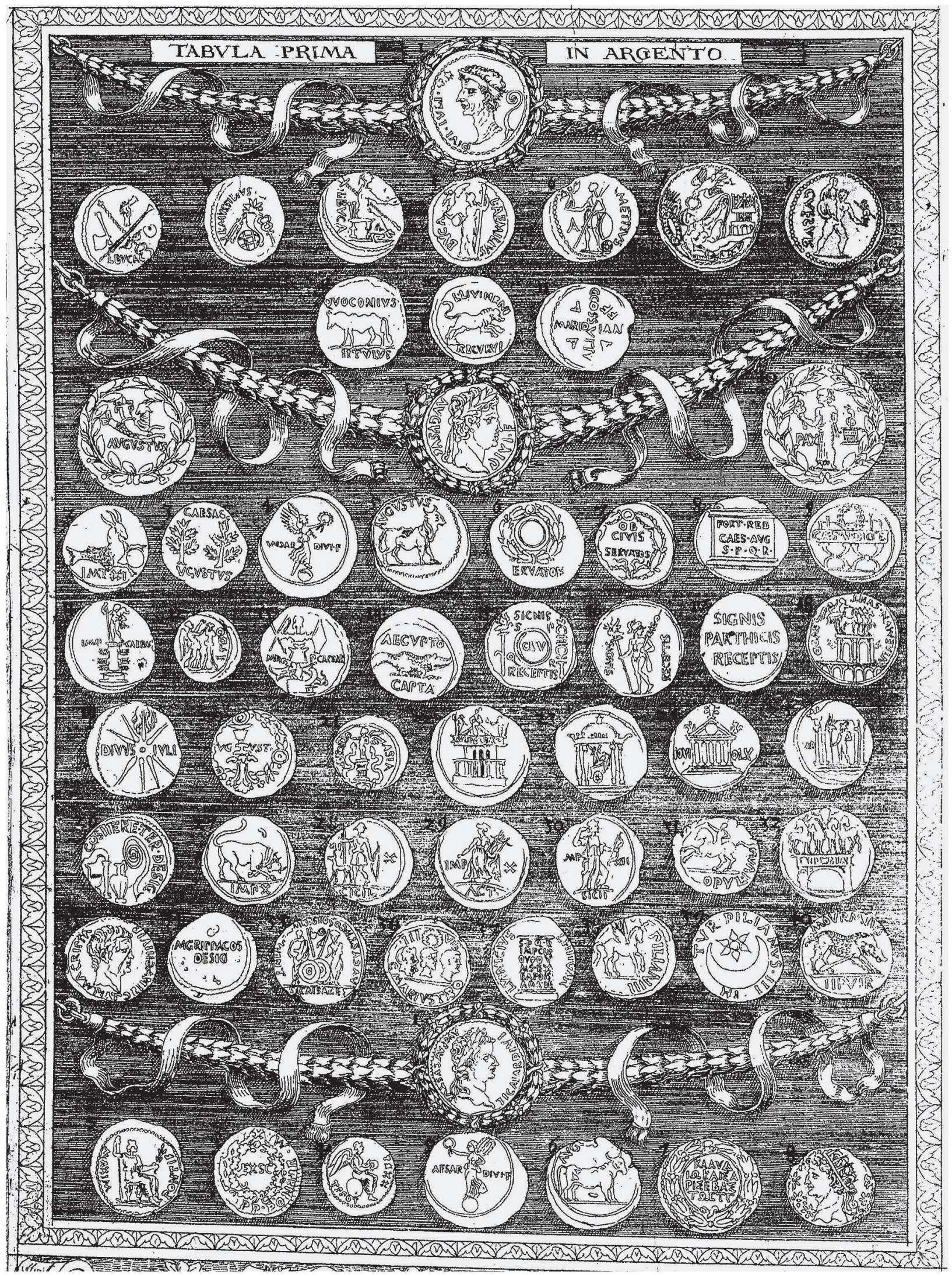

7. Hans Sebald Lautensack ókori érmeket bemutató táblája (részlet)

(Wolfgang Lazius: Commentariorum... Viennae 1558, AIIIv, ÖNB, Wien, Alt Prunk 57.C.11) 
lett a cím, dedikálta az új császár fiának a kötetet. A történethez hozzátartozik, hogy Panvinio a könyvét a szerkesztési hibák miatt egy éven belül javított formában újra kiadta (Fastorum Libri V. Velence 1558). ${ }^{71}$ Ez lett a római triumphusok 16. századi humanista recepciójának az egyik alapmüve Panvinio ókori Rómáról megjelentetett térképével (1553) és egy másik, posztumusz munkájával (De Triumpho Commentarius... Velence 1571) együtt. ${ }^{72}$

Strada végül 1558 végén Bécsbe utazott. A fenti antik tárgyú kiadványok jó ajánlólevélnek bizonyultak az új császári udvarba, ahol sikerült I. Ferdinánd szolgálatába lépnie. Ezt követően építészként és antikvitás-szakértőként vállalt szerepet az udvar múvészeti vállalkozásaiban. ${ }^{73}$ Többek között részt vett az említett Stallburg, valamint a Kaiserspital tervezésében, továbbá az I. Miksa-síremlék koncepciójának kidolgozásában.

\section{Az I. Miksa-síremlék végleges koncepciója}

A síremlék befejezésére I. Ferdinánd adott megbízást. A munkálatok az 1550-es évek elején gyorsultak fel, amikor tehát a bécsi, immár új császári udvarban a feliratos all'antica alkotások és a római antikvitások iránt egyre nagyobb érdeklődés mutatkozott. Ez jelentősen hatott a mü, valamint a neki otthont adó épület koncepciójára, amelyet ekkor véglegesítettek.

A síremlék rendkívül szerteágazó keletkezéstörténetét ${ }^{74}$ az alábbiakban kizárólag központi elemére, a tumbára koncentrálva mutatjuk be, amely Bocskay György antikva betüs feliratait hordozza. A mü az innsbrucki Hofkirchében található (8. kép). I. Miksa nagyméretű márványtumbája a főhajó közepén helyezkedik el (9-10. kép). A fedlapon, az oltár felé fordulva a császár életnagyságú bronzszobra térdel, amelyet a sarkokon a négy kardinális erény allegorikus bronzalakja vesz körül. A tumbán 24 márványrelief jeleníti meg I. Miksa életének főbb eseményeit, amelyeket a mellékhajó és a főhajó határán 28 (eredetileg 40) életnagyságúnál nagyobb, a Habsburg császárok felmenőit, rokonait és politikai mintaképeit ábrázoló álló bronzfigura vesz körül, kiegészítve az orgonakórus előtt 23 (eredetileg 100), a Habsburgházhoz köthető szent kisebb álló bronzszobrával. A szintén ide szánt 21 (eredetileg 34) római császárt ábrázoló bronzbüsztöt végül nem használták fel.

A kivitelezés még I. Miksa elképzelései szerint, az augsburgi Konrad Peutinger udvari humanista vezetésével kezdődött el (1502). A legkorábbi tervek a Diadalmenet, a Diadalkocsi és a Diadalkapu munkálataival párhuzamosan keletkeztek. A Diadalmenet- ben szerepeltek a síremléken szobor formájában megjelenítendő rokonok és ősök. A Diadalkapu császárportréi a tervezett büsztök, illetve az I. Miksa életéből vett jelenetei („Haupstück”) a tumba reliefjeinek az előképeként szolgáltak - bár egyelőre közvetett bizonyítékok támasztják alá, hogy egy tumba már ekkor is szerepelt az elképzelések között. ${ }^{75}$ A császár haláláig (1519) az egész együttesből csupán a bronzszobrok egy része, 11 ős, ${ }^{76} 19$ szent és 21 portrébüszt készült el.

Néhány évvel később I. Ferdinánd bízta meg Jörg Kölderer udvari festőt és építészt, hogy javasoljon megoldásokat a kész bronzszobrokból és egy szintén bronzszarkofágból álló együttes bécsújhelyi (Georgskapelle, illetve Neuklosterkirche) vagy bécsi (Stephansdom) felállítására (1527-28). Az uralkodó szerint a "díszes” és „arányaiban a szobrok nagyságához igazítandó" tumbát fedlapján I. Miksa fekvő, páncélos alakjával és oldalain a Diadalkapu 24 jelenetével kellett volna kivitelezni. ${ }^{77}$ Kölderertől mindhárom ekkori terv fennmaradt. ${ }^{78}$ Ezeken már látható az a - végül meg is valósult - koncepció, miszerint egy központi szarkofágot kétoldalt álló szobrok kísérnek. Azonban a tumba ezeken egyelőre csak igen vázlatosan, felülnézetben jelent meg.

Innsbruckban eközben folytatódott a bronzszobrok öntése. 1535-re egy kivételével már az összes, a síremlék körül ma is látható figura elkészült. Hoszszú szünet után, 1547-ben Wilhelm Schnurff, I. Miksa végrendeletének utolsó élő hitelesítője készített I. Ferdinándnak újabb javaslatot a folytatásra. ${ }^{79}$ Elvégezte az addig elkészült bronzszobrok számbavételét, majd ezek mellé ő is egy bronzszarkofág felállítását ajánlotta.

Ezt követően döntés született arról, hogy a síremléket Innsbruckban állítják fel, és itt egy külön épület készül a befogadására. A Hofkirche (Szent Kereszt-templom, 8. kép) és kolostor tervezését I. Ferdinánd utasítására 1549-ben kezdték el, alapkőletételére 1553-ban, felszentelésére pedig 1563ban került sor. A templom első tervei a Hofburgban ekkor zajló átalakítások modern, itáliai szellemiségét tükrözték. 1552-ben még Andrea Palladio neve is felmerült a felkérendő mesterek között. Végül az épület I. Ferdinánd és a konzervatívabb felfogást képviselő Felső-ausztriai Kamara hosszas egyezkedése folytán egy késő gótikus csarnoktemplom lett, amely csak részben tükrözte a bécsi udvar új, all'antica ízlését. Például az uralkodó elképzelése szerint a pillérkötegeket antik spoliumokra emlékeztető, hatalmas vörösmárvány ión oszlopok váltották (9. kép), a főhomlokzatra pedig egy szintén ión oszlopokkal tagolt, lunettával koronázott, színes márvány bejárati portál került (11. kép). ${ }^{80}$ 


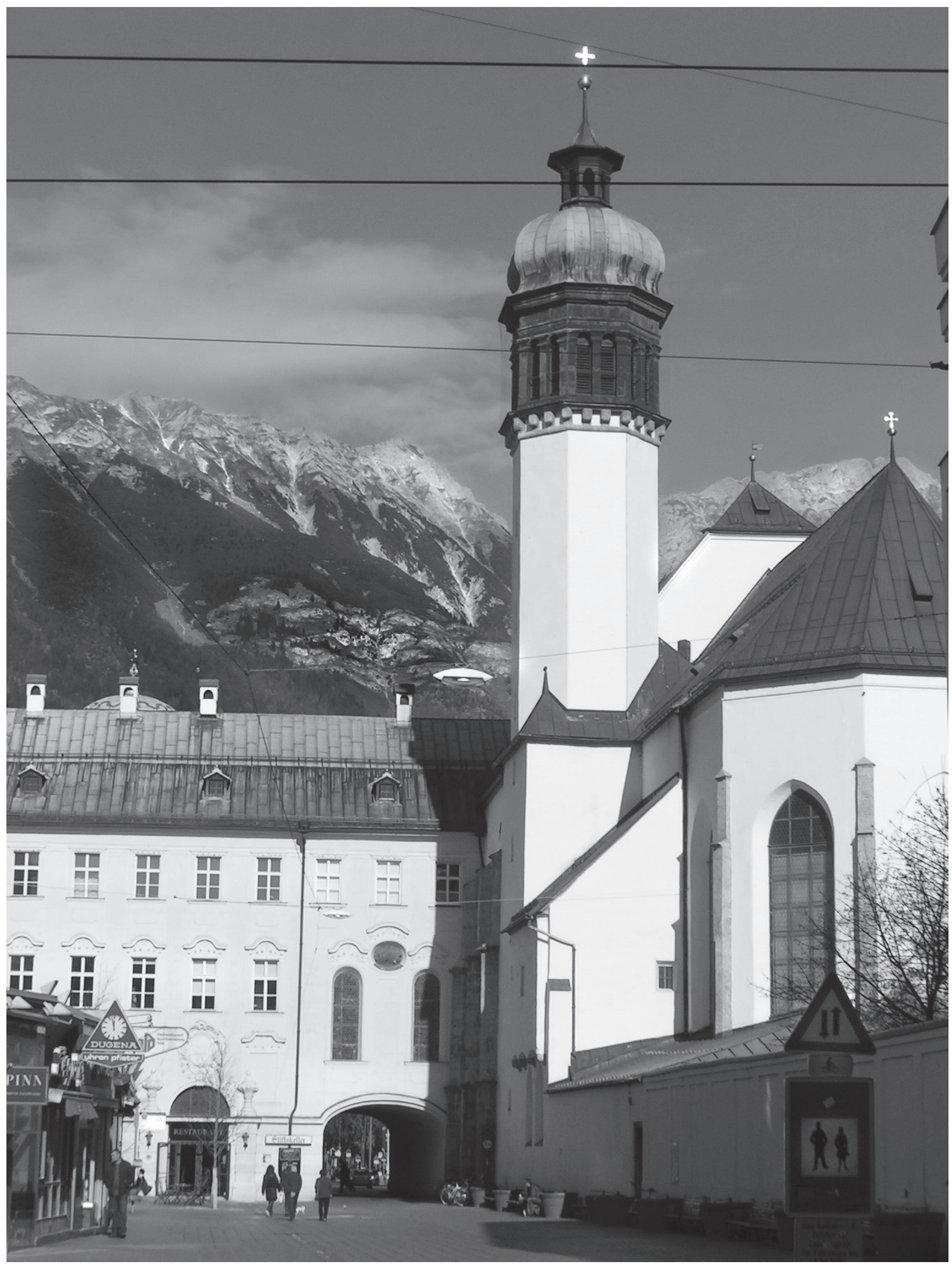

8. A Hofkirche dél felól (A szerző felvétele, 2008) 


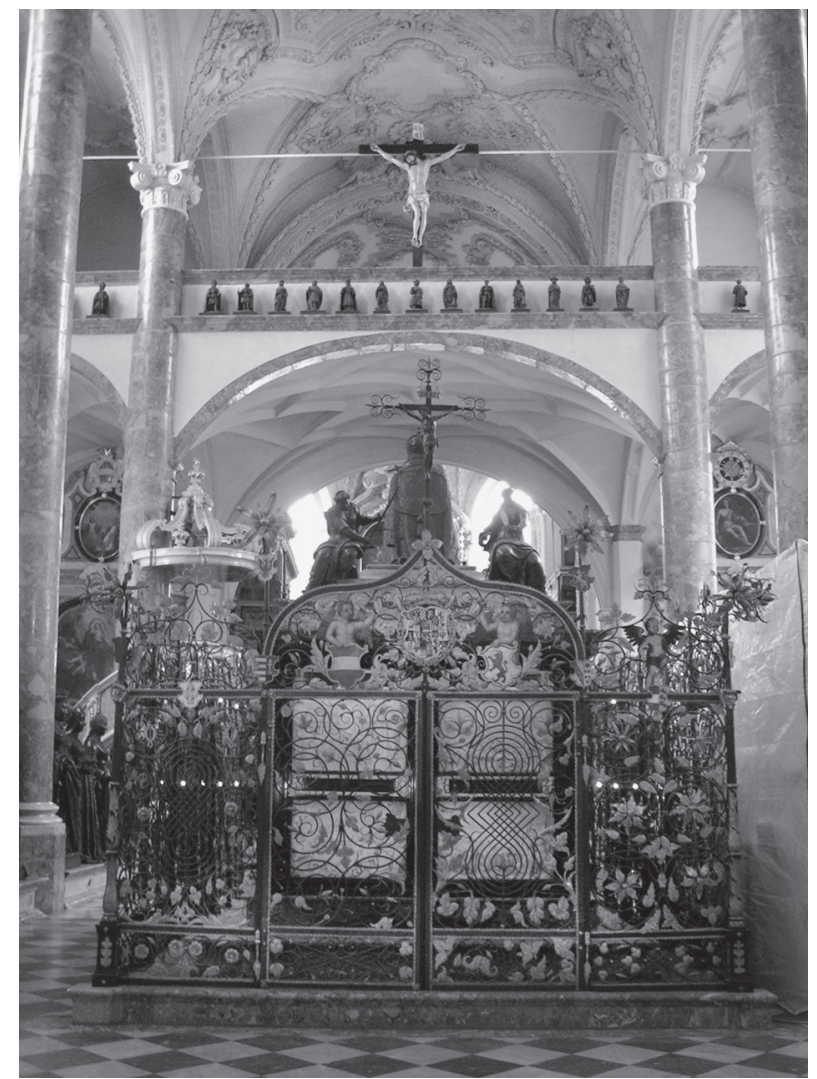

9. A tumba észak felöl (A szerző felvétele, 2008)
A bécsi udvarban a templom építésével párhuzamosan dolgozták ki a síremlék végleges koncepcióját. A folyamatot két, I. Ferdinánd felkérésére készült javaslat alapján lehet nyomon követni, amelyeket Hermes Schallauzer (4. kép) állított össze. Az építésfelügyelő elmondása szerint az első javaslat (1556 aug. előtt) ${ }^{81}$ kidolgozására azért került sor, mivel egy korábbi terv („Visierung”), amelyet I. Ferdinánd készíttetett a síremlékről, nem nyerte el az uralkodó tetszését. A „Visierung” feltehetően avval a méretarányos tervvel azonosítható, amely a tumba egyik hosszoldalát ábrázolja $(209,5 \times 474$ $\mathrm{cm}, 12$. kép). ${ }^{82} \mathrm{~A}$ szakirodalom a datálatlan és szignálatlan múvet 1560 körülre teszi, és annak a Florian Abel festőnek tulajdonítja, aki később a reliefek vázlatait készítette. ${ }^{83}$ A rajznak azonban még Schallauzer itt idézett első javaslata előtt kellett keletkeznie. Az ebben ajánlott elemekből ugyanis több hiányzik róla (pl. címersor, feliratos fríz), a reliefek képaláírásai pedig nem latin nyelvűek, ahogyan erről az irat beszámol, hanem a Diadalkapu német verses szövegeit veszik át. Az azonban már antikizáló tendencia, hogy a rajzon a feliratok nem a Diadalkapun használt gót fraktúrral, hanem klaszszikus antikva kapitálissal íródtak.

Visszatérve az első javaslat ismertetéséhez, Schallauzer elöször sorra vette benne a kész bronzszobrokat, amelyeket szerinte mind fel kellene

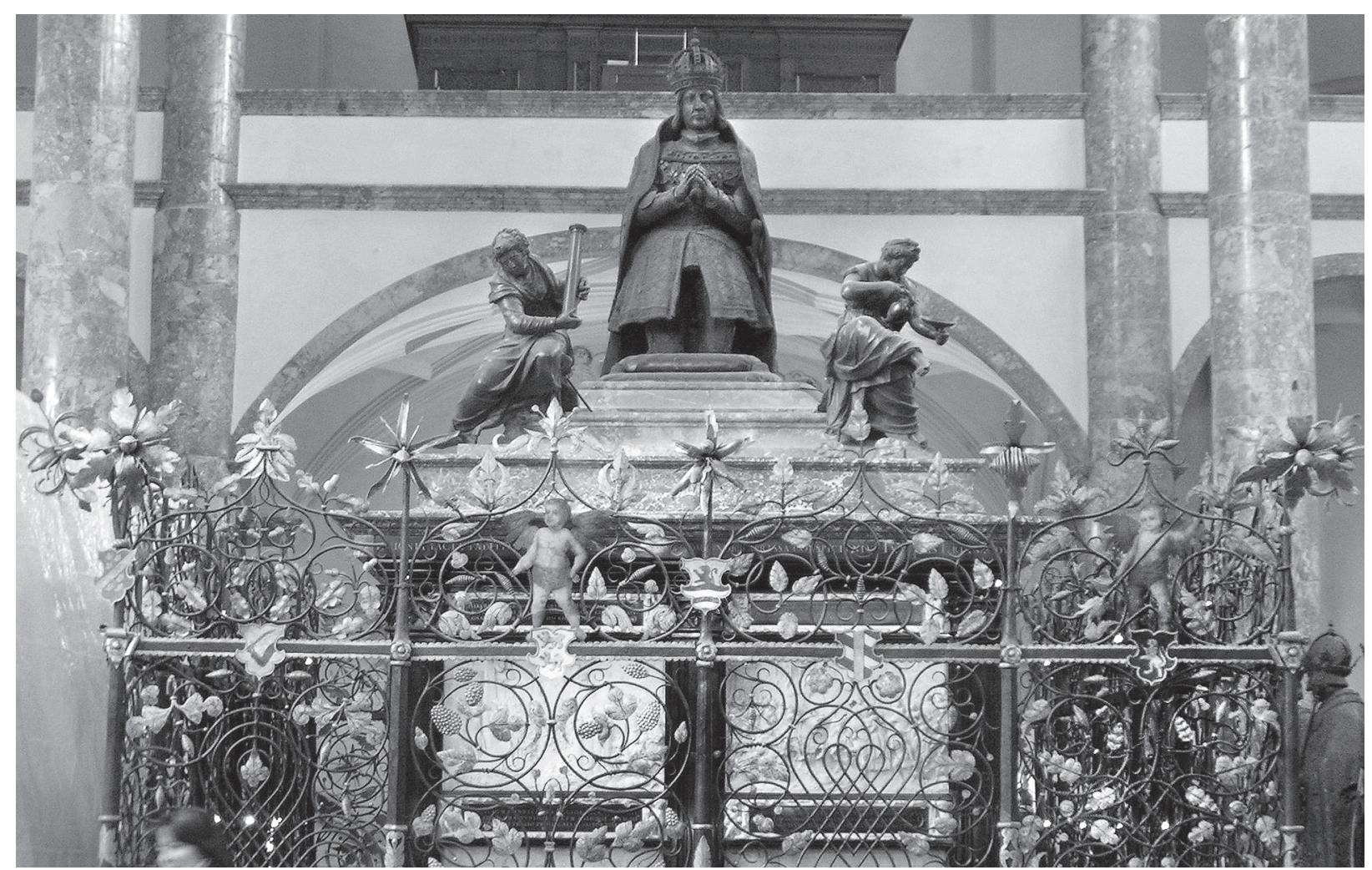

10. A tumba dél felól (A szerző felvétele, 2008) 
állítani a sír körül: az ősöket a tumba mellett, a szenteket fenn a pilléreken, a császárbüsztöket a két empóriumon. Majd részletesen leírta az általa elképzelt bronztumbát, a felső részén a Diadalkapu címersorával és egy feliratos frízzel, valamint az oldalfalain a Diadalkapu 24 jelenetével. Azt is megemlítette, hogy az uralkodó kancellárja I. Ferdinánd utasítására átültette a Diadalkapu német verseit és a sírfeliratot latinra. Tehát itt már nem a korábbi terven (12. kép) látható német, hanem latin szövegekkel számoltak. Az említett személy Georg Sigmund Seld $^{84}$ birodalmi alkancellárral azonosítható, akivel mint a végleges szövegek összeállítójával még foglalkozunk. Schallauzer folyamatosan hivatkozott az I. Ferdinándnak mellékletként küldött vázlatokra is, amelyek azonban ma már hiányoznak az irat mellől. ${ }^{85}$ Az egyiket „Francesco mesterrel, Ferdinánd főherceg udvari festőjével”, vagyis Francesco Terzióval ${ }^{86}$ tervezte elkészíttetni. Ezért valószínü, hogy egy Terziónak tulajdonított rajz, amely a tumbát ábrázolja, e javaslattal összefüggésben keletkezett (13. kép) ${ }^{87}$. A mü a szarkofágot oldalnézetből mutatja, a Schallauzer által javasolt címersor, a feliratoknak szánt fríz, valamint az oldalfalakon a Diadalkapu 24 álló formátumú jelenetének a helye is megtalálható rajta.

A tervek továbbra sem felelhettek meg I. Ferdinánd elképzelésének, ezért Schallauzer első javaslatát 1559-1560-ban egy második is követte. ${ }^{88} \mathrm{Ez}$ már nem egyedül hozzá köthető, hanem egy egész tanácsadó testület munkája: az élén szerepel a bécsi all'antica udvari reprezentáció néhány további meghatározó alakja, Pietro Ferrabosco, Jacopo Strada, valamint Natale Veneziano is. A tanácsadók itt már a korábbi bronz- helyett egy márvány-

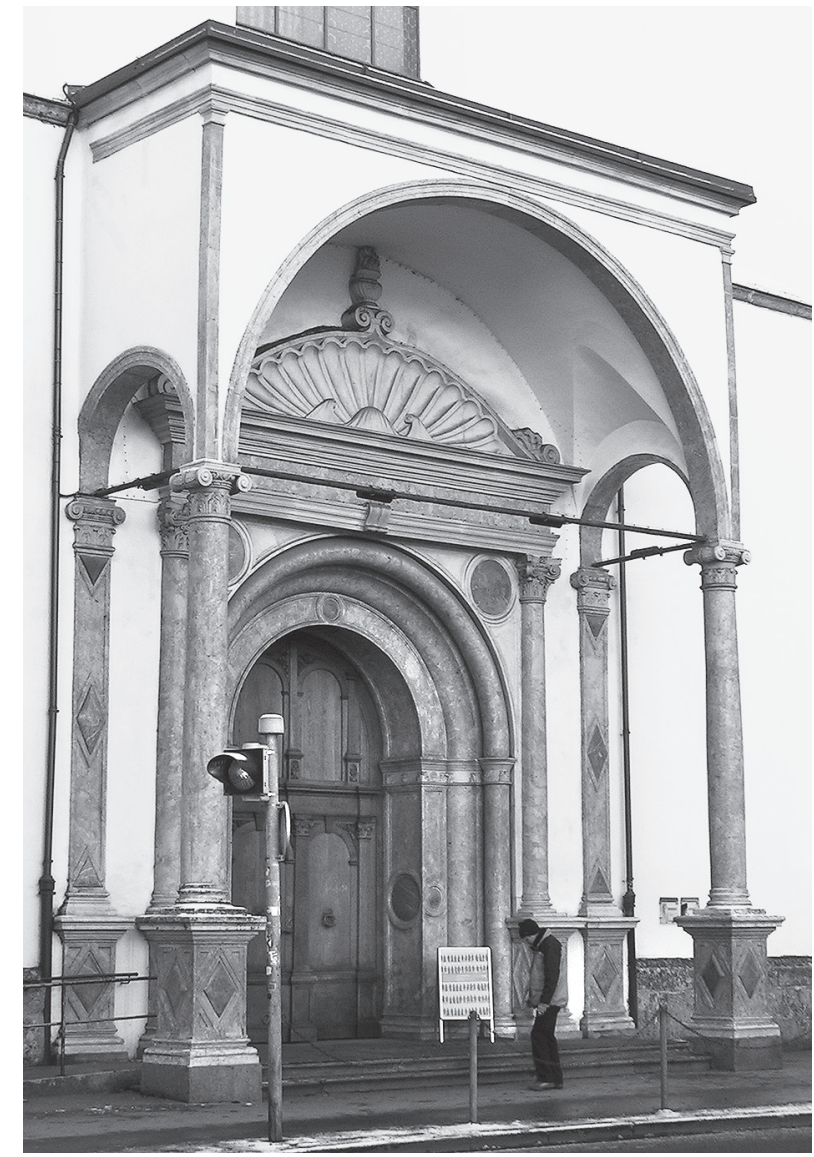

11. A Hofkirche északi fóportálja (A szerző felvétele, 2008)

tumba felállítását javasolták. Ehhez a következő színü márványokat ajánlották: vörös-fehér kevert lépcsőfokok, 24 „szép fehér" relief fekete kerettel, a képaláírások fehér táblán fekete betükkel („die Epitauÿ der hÿstorÿ vom Weissem Märblstain mit

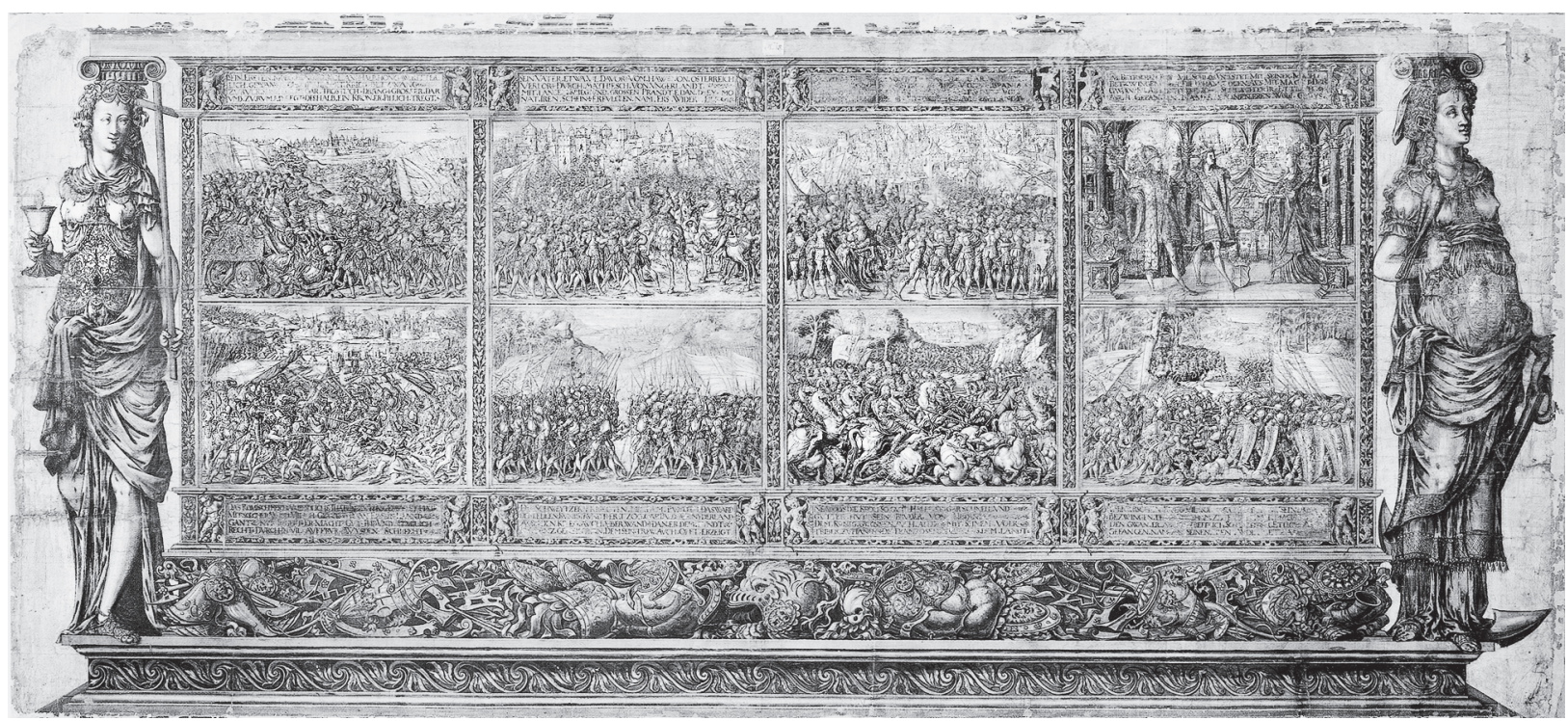

12. A tumba méretarányos terve (Kunsthistorisches Museum, Wien, Inv-Nr. KK 4971) 


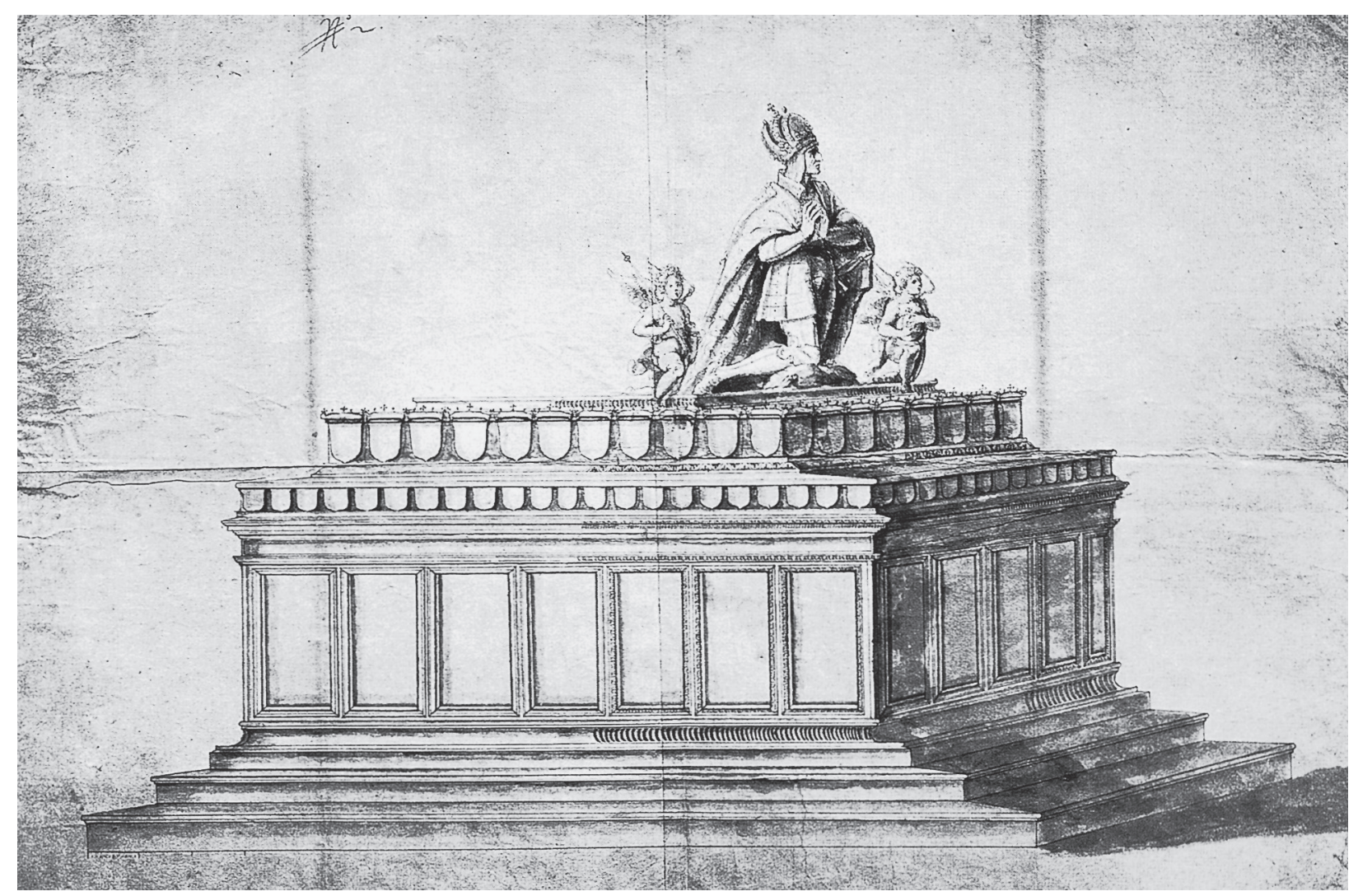

13. Francesco Terzio: A tumba terve (Albertina, Wien, Inv.-Nr. Arch 9685)

schwarzem Puechstaben"), vörös-fehér párkány, fölötte „két fehér foknyi” lépcső (azaz a fedlap), ebből az alsón a sírfelirat szintén fekete betűkkel („,der Kay: Mt: Haubt tittl von schwarzem Puechstaben"), míg a fölsőn bronz címersor. Szintén bronzból képzelték el a tumba alján a másik körbefutó címersort, valamint tetején a térdelő császár és az őt körülvevő címertartó hat puttó és négy sas, valamint a sarkokon a négy erény figuráját.

Tehát a márványtumba koncepciója Schallauzer és az udvarban szolgáló itáliai szakértők tanácsai alapján alakult ki. A felső lezárás fehérről Rotscheckre cserélését, a bronz címertartó figurák és a két címersor elhagyását (lent trófeumok kerültek az utóbbi helyére) kivéve valóban ez a tervezet épült meg. Dorothea Diemer tanulmányában a javaslatban megfogalmazott márvány ötlete mögött Jacopo Strada személyét sejti, és a márvány kisebb költségét hangsúlyozza a bronzhoz képest. ${ }^{89}$ Emellett a márvány és a klasszikus antikva feliratok az uralkodó és a bécsi udvar all'antica ízlésének jobban megfeleltek. Ezt támasztja alá az az 1561-ben kelt beszámoló is, amelyet az innsbruckiak a síremlék mestereinek kőbeszerző körútjáról küldtek Bécsbe I. Ferdinándnak..$^{90}$ Eszerint Arnold Abel az uralkodó utasítására Rómában és Itália más városaiban „műalkotásokat és antikvitásokat" nézett meg. A német kőfaragónak tehát az is a feladatai közé tartozott, hogy a tumba megkezdése elött a modern, itáliai stílust, valamint az ókori római régiségeket tanulmányozza.

Ami az antikvitásban szintén fontos szereppel bíró bronzot illeti, ez a változtatást követően is a javaslat része maradt. A tumbán megtartották a császár és a négy erény figuráját, valamint körülötte az álló szobrokat. Ugyanakkor a sorozatból végül kimaradtak a római császárok (Julius Caesar álló szobra, 34 portrébüszt). Előbbit több más alakkal együtt a megnövekedett költségek miatt nem öntötték ki. ${ }^{91}$ A 34-ből már meglévő 21 császárbüszt pedig Schallauzer első javaslatában még szerepelt, az empóriumra került volna, később azonban ide az álló szenteket helyezték el. Bármennyire is illettek volna a síremlék all'antica koncepciójához, a források egyelőre nem teszik lehetővé, hogy kihagyásukra megnyugtató magyarázatot találjunk. Az elkészült büsztök ehelyett valószínúleg Ferdinánd főherceg ambrasi gyüjteményébe kerültek. ${ }^{92}$

$\mathrm{Az}$, hogy a síremléken antikizáló, latin feliratokat használnak majd, szintén ekkor dőlt el. A márványtumba all'antica építészeti dekorációján belül az antikva betüs szövegek hangsúlyos díszítőelemként működtek. A római eredetü, klasszikus kapitálissal írott feliratok azt a benyomást keltették, 
mintha a császár életéből vett jelenetek ókori epigráfiai emlékek révén elevenednének meg. Ennek jelentősége a szövegek létrejöttét áttekintve válik világossá. Ugyanis kezdetben még a latin sem szerepelt a tervek között. Mint bemutattuk, I. Ferdinánd környezetében hosszú ideig az az elképzelés élt, hogy a tumba reliefjeit a Diadalkapu 24 jelenete alapján kell elkészíteni. Ezek pedig I. Miksa udvari humanistájának, Johannes Stabiusnak egy-egy német nyelvü, hatsoros versével voltak ellátva. A Diadalkapunak létezett egy kevesebb kiadást megért változata is, latin nyelvü, prózában írt képaláírásokkal. Szerzőjük Benedictus Chelidonius bencés szerzetes volt, aki I. Miksa megbízásából végezte el a mü teljes szövegének latinra fordítását. ${ }^{93}$ A tumbára azonban nem az ő szövegei kerültek.

I. Ferdinánd először latinra fordíttatta Stabius német verseit, majd pedig teljesen új, még antikizálóbb, latin prózai szövegeket iratott. A feliratok az említett Georg Sigmund Seldtől származtak, akit még V. Károly nevezett ki birodalmi alkancellárrá, és ezt a hivatalát egy rövid szünet után a bécsi udvarban is megtarthatta. Schallauzer első javaslatából ${ }^{94}$ még arról értesültünk, hogy Seld a Diadalkapu német szövegeit fordította le latinra. Ezt követően azonban szintén az uralkodó felkérésére további kutatómunkába fogott és átformálta a tumbára kerülő teljes reliefciklust beleértve a saját latin fordítását is. ${ }^{95}$

Seld a 24 jelenethez olyan új, klasszikus latinsággal megírt magyarázó szövegeket csatolt, amelyeket antikizáló utalásokkal - például ilyen csengésü személy- és népnevekkel - töltött meg. Ezek a képaláírások kerültek utóbb Bocskay György révén a tumbára (1. Függelék I/a). A megfelelő epizódok kiválasztása érdekében pedig összegyüjtötte az I. Miksa uralkodásával kapcsolatos történeti forrásokat. Hol kissé megszépítette, hol pedig pontosította a történetet, epizódokat vett ki, illetve rakott hozzá a sorozathoz, így végül a Diadalkapu 24 jelenete közül mindössze 11-et használtak fel teljes egészében, 3-at pedig némi változtatással. A reliefciklus ezáltal az aktuális történeti kívánalmaknak megfelelőbb és időrendileg ${ }^{96}$ kiegyensúlyozottabb lett: 1500 előttről és utánról egyaránt 12-12 eseményt mutatott be, szemben a Diadalkapu 16-8-as eloszlásával.

Miután Seld összeállította a tumba végleges képciklusát, és megírta a hozzá tartozó új latin feliratokat, a szövegekből több listát állított össze, amelyeket az alábbiakban mutatunk be. ${ }^{97}$ Az egyikben, amely az említett Florian Abelnek, a dombormüvek tervrajzait kivitelező festőnek szólt, az egyes jelenetek kompozícióira is javaslatot tett. ${ }^{98}$ A 24 képaláíráshoz az ábrázolásokra vonatkozó latin nyelvü utasításokat füzött. Ötnél a Diadalkapu adott jelenete volt számára a kiindulópont, négynél (4., 12., 13.,
23.) azt írta: antikizáló képet kér („Maneat pictura antiqua"), a többinél pedig az általa kívánt új ábrázolást részletezte. Seld a lista összeállítása után is nyomon követte Florian munkáját, aki a reliefek terveit („Visierung") először mindig neki küldte Bécsbe véleményezésre, és csak ezt követően továbbították őket a tumbán dolgozó másik két Abel fivérnek Innsbruckba. ${ }^{99}$

A további fennmaradt listák alapján arra következtethetünk, hogy a 24 képaláíráson kívül a sírfeliratot is Seld fogalmazta. Ez került azután szintén Bocskay kivitelezésében a tumbára (1. Függelék I/b). A terjedelmes latin szöveg I. Miksát, valamint a síremlék felállítójaként megnevezett I. Ferdinándot egyaránt kegyes császárként méltatja. A Bécsben őrzött Seld-féle listák között található egy olyan tisztázat, amelyben a 24 képaláírás mellett a sírfelirat végleges szövege is szerepel. ${ }^{100} \mathrm{Az}$ irat a rajta található név alapján Alexander Colin szobrász tulajdonában volt, aki az Abel fivérek halála után folytatta a tumba kivitelezését. E bővebb, a képaláirásokat és a sírfeliratot egyaránt tartalmazó listának számos további példánya őrződött meg Innsbruckban. Az egyik („Monumenti Epigrammata”) szintén Colin mühelyéből kerülhetett mai őrzési helyére, az Innsbruckhoz közeli Schwaz ferences kolostorába. ${ }^{101}$ Itt egy olyan áttekintés is fennmaradt, amely a síremlék teljes megvalósult koncepcióját (szobrok, reliefek, szövegek) pontokba szedve tartalmazza (1560 k.). ${ }^{102}$ A sírfelirat mellett az a megjegyzés olvasható benne, hogy ez a helyes szöveg, és a sok elkészült változat közül ez tetszett leginkább a császárnak. Vagyis az alkancellár a tumba szövegeit I. Ferdinánddal folyamatosan egyeztette, és az általa jóváhagyott feliratok kerültek végül a síremlékre.

$\mathrm{Az}$ imént bemutatott listák mind datálatlanok. Mivel egyikük Florian Abel részére készült, csupán annyit állapíthatunk meg, hogy a 24 képaláírás és a reliefek kompozícióinak említett listája 1561 tavaszán már készen volt. Ekkor kötöttek ugyanis szerződést a tumba kivitelezésére a három kölni származású mesterrel, Berhard és Arnold Abel kőfaragóval, valamint a festő Floriannal. ${ }^{103}$ Előbbiek a tumba innsbrucki munkálatait, utóbbi pedig a reliefek méretarányos vázlatait („Visierung”) vállalta, amelyeken Ferdinánd főherceg festőjeként Prágában dolgozott. Haláláig összesen 20 további vázlatot készített el (az utolsó kettő egy ismeretlen prágai mester munkája), amelyeket tehát Bécsen keresztül juttatott el Innsbruckba. A szerződés a tumbát a Schallauzer-féle második javaslattal megegyezően írta le. A különbség annyi, hogy a tumbafedélen a címertartó puttók, illetve sasok még szerepeltek benne, ezeket később feltételezhetően anyagi okokból elhagyták. A feliratoknál történt még kisebb 
változtatás. Ekkor már nem fehér alapon fekete, hanem fekete alapon arany feliratokat említettek, amelyeket egy további fehér keretbe terveztek beilleszteni. A szintén fekete-arany sírfeliratot pedig a tumbafedél alsó pereme helyett a koronázópárkány frízén képzelték el.

1561-re összeállt tehát a tumba végleges koncepciója, megbízták a mestereket, és elkezdődött a szükséges márványok beszerzése és Innsbruckba szállítása. A reliefekhez például I. Ferdinánd utasítására carrarai fehér márványt választottak. ${ }^{104}$ A fivérek igen lassan haladtak a munkával: 1562 júniusában a két kőfaragó mindössze egyetlen dombormúvet kezdett el, ezenkívül befejeztek hat darab fehér márvány keretet, amelybe várták a feliratos fekete táblákat. ${ }^{105}$ Azonban a tumba felirataihoz és antikizáló architektúrájához használt fekete márvány lelőhelyéről csak valamivel később született döntés. 1561 októberében tájékoztatták Innsbruckból a bécsieket, hogy sikerült a megfelelő kőre Trento környékén rátalálni. ${ }^{106}$

\section{Egy antikizáló kézirat és a megbízás elnyerése (1562)}

Tehát a reliefek és a fehér keretek Innsbruckban már készültek, a feliratos táblák fekete márványának a lelőhelye is eldőlt, Seld alkancellár végleges szövegei pedig Bécsben rendelkezésre álltak, azonban a feliratok mesterének a kérdése még nyitott volt. Bocskay György e ponton csatlakozott az eseményekhez. A kalligráfus az udvarba bejáratos emberként bizonyára ismerte a síremlék befejezésére vonatkozó elképzeléseket. Miután felmérte az ebben rejlő lehetőséget, 1562-ben egy antikizáló kéziratot készített I. Ferdinándnak, amelyet mintának szánt a síremlék felirataihoz. ${ }^{107}$

Az írásmintakönyv élére egy, a császárnak szóló ajánlást helyezett el. Bár ebben úgy fogalmazott, hogy I. Ferdinánd akaratából készítette el a kéziratot, valószínübbnek tartjuk, hogy a mű a kalligráfus önálló kezdeményezésére, a megbízás elnyerésének reményében született. Az ajánlásban találóan indokolta meg, hogy erre miért ő a legalkalmasabb. Egy „pannóniai ősi nemesi család sarjaként" mutatta be magát, aki régóta híven szolgálja uralkodóját. Saját képességeit büszkén, a kívánatos hívószavakról („ars”, ,,ingenium”) sem elfeledkezve méltatta, aki "müvészetének örök tanúbizonysága végett", "tehetségének ritka és egyedülálló ügyessége révén" hozta létre e „különböző formájú betűkkel díszített könyvet" (1r). ${ }^{108}$

A kézirat vízszintes formátumával és szokatlanul nagy méretével szintén felhívja magára a figyelmet. Ha képzeletben a síremlék egyik képaláirása

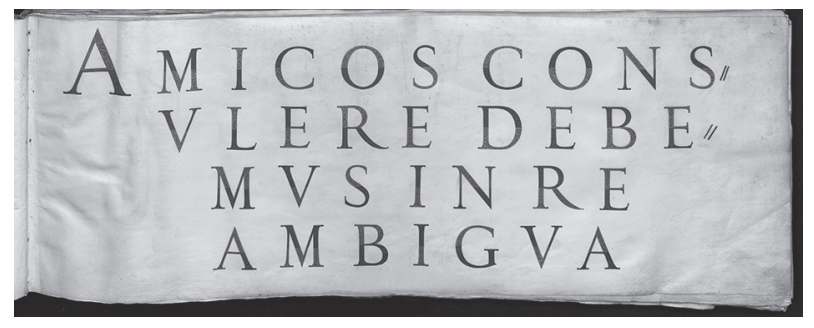

14. Bocskay György írásmintakönyve (1562), $2 r$ (ÖNB, Wien, Cod. ser.n. 2664)

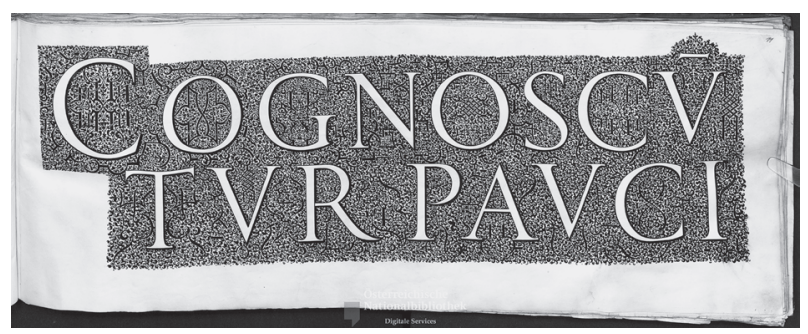

15. Bocskay György írásmintakönyve (1562), 11r (ÖNB, Wien, Cod. ser.n. 2664)

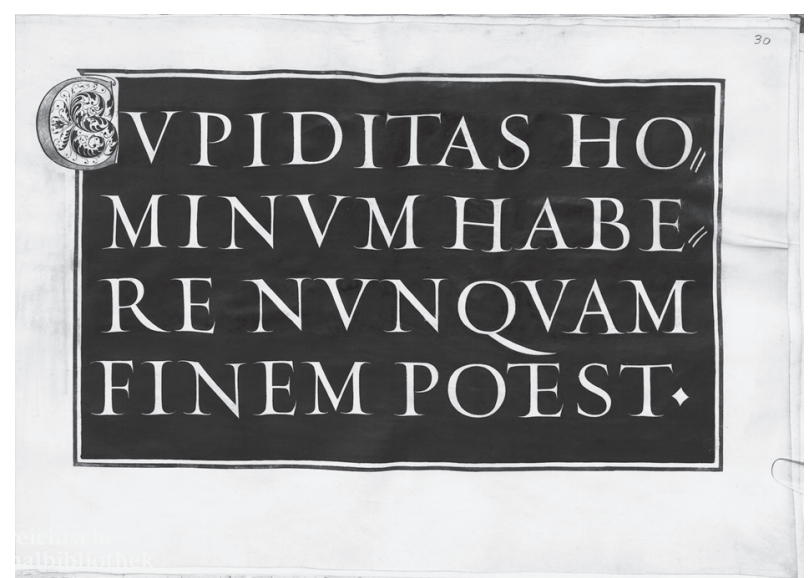

16. Bocskay György írásmintakönyve (1562), 30r (részlet) (ÖNB, Wien, Cod. ser.n. 2664)

mellé tesszük, kiderül, hogy azonos formátumúak és közel azonos méretüek: a kézirat lapjai átlagosan $25 \times 67$, a feliratos táblák pedig $9,5 \times 67 \mathrm{~cm}$-esek. Itt tehát nem véletlen egybeesésről van szó, hanem arról, hogy a kalligráfus Bécsben valami módon már birtokába került a síremlékre vonatkozó előzetes információknak.

A kézirattal kapcsolatban további szembetűnő jelenség a klasszikus antikva kapitális írásminták nagyarányú szerepeltetése, amelyek az ókori epigráfiai emlékeket imitálják (14. kép). Egyaránt vannak köztük antik auktoroktól, a Bibliából és a latin egyházatyáktól származó citátumok, a betűk színe és háttere szintén variálódik (színes, arany és ezüst mustrával kitöltött betűk, szalagfonatból vagy akantuszlevélből összeálló betűtestek, ornamentális hátterek, 15. kép). A síremlék feliratainak ek- 
korra megszilárdult kritériumaihoz - fekete alapon arany betük - két írásminta áll közel (15-16. kép). E változatosság magyarázatát abban kereshetjük, hogy a kalligráfus azt kívánta bemutatni, nem csupán az antik feliratok magas színvonalú utánzására alkalmas, de saját képességei révén túlszárnyalni is képes az ókori példákat.

Az írásmintakönyv és a síremlék feliratainak az összefüggését a kézirat két egykori őrzési helye is valószínűsíti. A császár a neki ajánlott írásmintakönyvet átvétele után nagy becsben tarthatta, mivel egy rendkívül igényes egészbőr kötést csináltatott hozzá. Erre az aranyozott, vaknyomásos díszítményekből következtethetünk, amelyek leghangsúlyosabb eleme a kompozíció közepére került császári sas (17. kép). I. Ferdinánd 1564-ben bekövetkezett halála után fia, Ferdinánd főherceg örökölte apja gyüjteményének egy részét, amelyben minden bizonnyal a kéziratot őrizték. Néhány évtizeddel később ezért tünhetett fel az Innsbruck melletti Ambrasban, az ő Kunstkammerében, amelynek legkorábbi inventáriumában (1596) írták le. ${ }^{109}$ Szintén 1564-től a főherceg irányította - már tiroli helytartóként - a síremlék befejezését. Ennek kapcsán, mint még látni fogjuk, személyesen is találkozott Bocskayval. ${ }^{110}$ Így a pompás írásmintakönyv a mü létrejöttének egyik dokumentumaként is felkelthette a figyelmét.

\section{A maratott feliratok kivitelezése (1563-1568)}

A kalligráfusnak tehát 1562-ben sikerült elérnie, hogy I. Ferdinánd megbízza a síremlék antikizáló feliratainak az elkészítésével. Ekkor Innsbruckban Berhard és Arnold Abel már dolgozott a tumba szobrászati részén, fivérük, Florian pedig folya- matosan küldte nekik a terveket. 1563-1565 között azonban mindhárman meghaltak. Csupán egy teljes és két félkész reliefet, hat felirathoz tartozó fehér keretet, valamint 20 tervrajzot készítettek el. Ezért bízták meg a Seld-féle listák kapcsán említett Alexander Colin mechelni szobrászt, hogy mühelyével folytassa a tumba munkálatait.

Mindeközben Bocskay a feliratokon Bécsben dolgozott, ez kalligráfusi múködésének a források alapján legjobban nyomon követhető időszaka. ${ }^{111}$ E távolságból később sok nehézség adódott, például a hosszú vízi úton a táblák eltörtek, oda-vissza szállításuk pedig alapos szervezést igényelt. Láthatóan ki is használta, hogy titkári teendői Bécshez kötötték, és így nem az innsbrucki vezetés látóterében kellett dolgoznia. Az állandó sürgetések ellenére nagyon lassan haladt a munkával, amely így összesen öt évet vett igénybe.

Korábban utaltunk rá, hogy a tumbához szükséges fekete márványt 1562 őszén az Innsbruckhoz viszonylag közel fekvő Trento környékén találták meg. ${ }^{112} 1563$ áprilisában küldték el az itteni közvetítőnek a szükséges tömbök méreteit, ${ }^{113}$ így az első szállítmány valamikor ezt követően került a síremlék helyszínére. Evvel függhetett össze, hogy Bocskay 1563 májusában parancsot kapott, hogy csatlakozzon az Innsbruckban tartózkodó I. Ferdinándhoz és udvarához. ${ }^{114}$ Ezért Miksa főherceg utasította a Magyar Kamarát, hogy e célból folyósítson Bocskay György „,analligrafus” részére $50 \mathrm{Ft}$ útiköltséget. ${ }^{115} \mathrm{Az}$ elsőre különösnek tűnő "évkönyvíró" titulus kizárólag ebben a forrásban tünik fel a neve mellett. Evvel bizonyára arra utaltak, hogy ő a képaláírások készítője, amelyek az I. Miksa életéből vett jelenetekhez tartoznak. Tehát Innsbruckban elsősorban nem titkárként, hanem a feliratok kivitelezőjeként számítottak rá. Itt azután

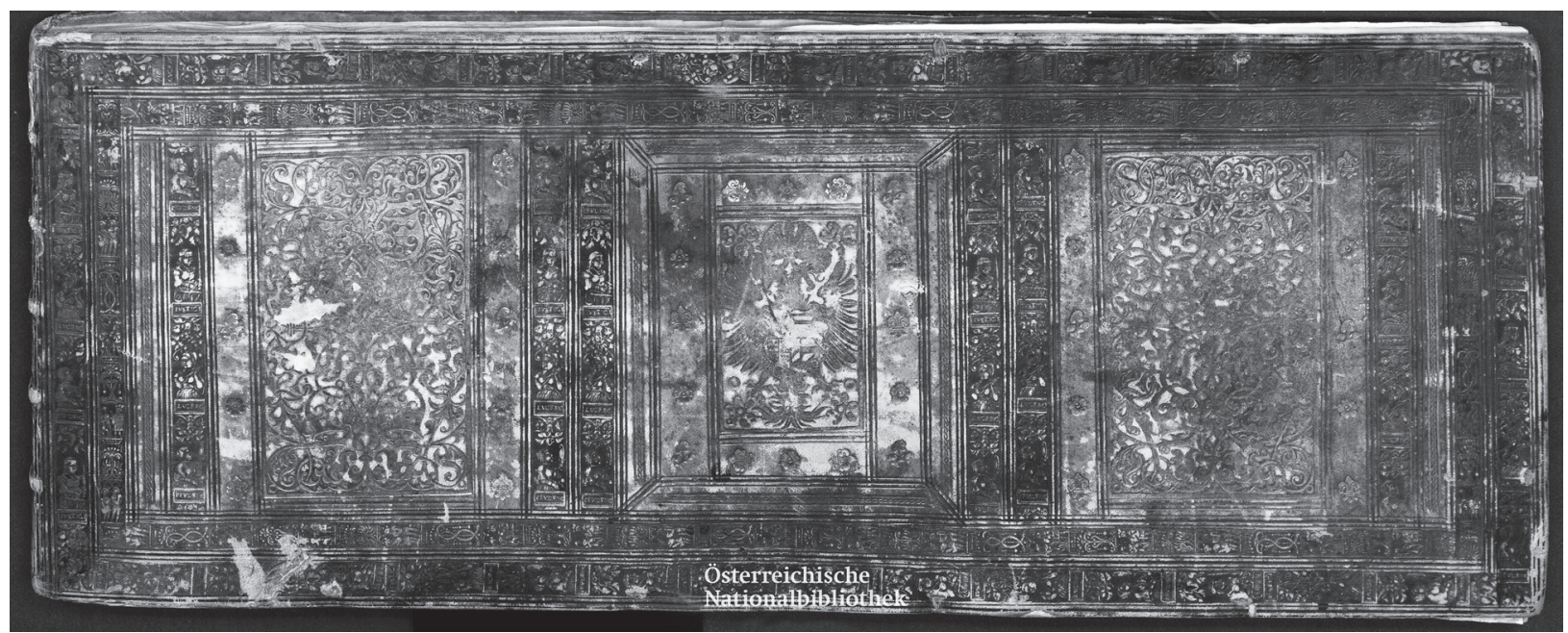

17. Bocskay György írásmintakönyve (1562), a kötés első táblája (ÖNB, Wien, Cod. ser.n. 2664) 
lehetősége nyílt személyesen konzultálni azok elhelyezéséről, valamint megtekinteni a tumba már elkészült részeit, például a feliratos tábláknak szánt fehér kereteket.

A források szerint a fekete márvány méretre vágását Innsbruckban végezték, és kész lapokat szállítottak Bocskaynak Bécsbe, hogy azokon a feliratokat kivitelezze. Ezekből az első ládányit a Felsőausztriai Kamara Innsbruckból 1563 októberében továbbította. ${ }^{116}$ Azonban a kalligráfus a következő év nyaráig sem küldte vissza a kész feliratokat. 1564 júliusában megérkezett az első innsbrucki sürgetés, azt kérték I. Ferdinándtól, hogy mielőbb küldesse el nekik a befejezett táblákat. ${ }^{17}$ A császár halála után a Felső-ausztriai Kamara az új uralkodót, II. Miksát is tájékoztatta a késlekedésről. ${ }^{118} \mathrm{Be}-$ számolójuk szerint I. Ferdinánd kívánságára és utasítására („,beuelch und verordnung”) Bécsbe küldték Bocskaynak a $24(\text { sic! })^{119}$ táblát $(, 24$ marblstain schwarz tafelein”), hogy a képaláírásokat („Die Epitaphÿen od[er] Tittl der hÿstorien") maratással és aranyozással elkészítse (,zu ätzen und zu vergolden"). Nem tudják viszont, most dolgozik-e rajtuk, azt ellenben fontosnak tartják, hogy a márványtáblákat alaposan filcbe csomagolva küldje vissza, mert azok finomak és törékenyek („,mar [ = mürbe] und prüchig [= brüchig]").

Tehát e levél is arról tudósít, hogy Bocskayt I. Ferdinánd bízta meg a feladattal. Arról is hallunk, hogy a feliratok kőmaratással készültek. Az eljárás hasonló elven alapult, mint a 19. században elterjedt litográfia. A kőlap egyes részeit saválló (olajos) anyaggal kenték be, míg más részeit a készítendő ábrázolásnak megfelelően szabadon hagyták, így a maratás után az utóbbi területek mélyebbek lettek és kialakult a kívánt minta. ${ }^{120}$ Bocskay a feliratainál a ritkább, ún. mélymaratást („Tiefätzung”) ${ }^{121}$ alkalmazta. Itt a teljes felületet bevonták az olajos anyaggal, majd az ábrázolandó részeket kikaparták, így a maratást követően a minták mélyedtek be a kőlapba. A kalligráfus ehhez bizonyára valamiféle sablont használt, amely segítségével a betűk azonos méretüek és egyenletes elhelyezkedésüek lettek. Az eljáráshoz savra reagáló mészkövet vagy ritkábban márványt használtak. Bocskaynál mindkettőre találunk példát: a később tárgyalandó lékai táblák solnhofeni mészkőből, ${ }^{122}$ míg az innsbruckiak fekete márványból ${ }^{123}$ vannak. A helyszíni vizsgálat alapján mind Lékán, mind Innsbruckban a vájatok mindössze 1-2 milliméter mélységűek, belső felületük egyenletes, középen nem mélyülő, amely arra utal, hogy valóban az említett maratással és nem véséssel készültek (18. kép). Ezt követően Bocskay aranyozta a feliratokat. A lékai feliratokkal kapcsolatban ő maga utalt rá, hogy épp most

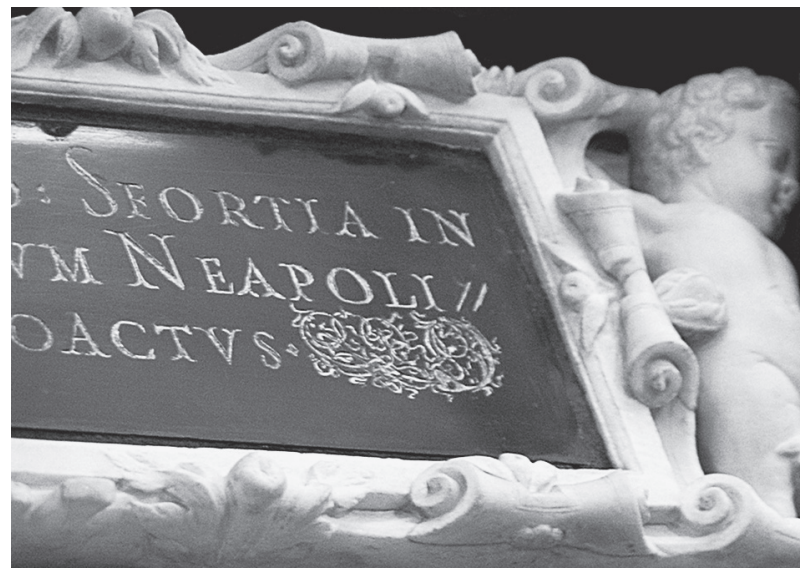

18. A 10. képaláirás részlete (A szerző felvétele, 2008)

készíti az aranyozásukat. ${ }^{124} \mathrm{Az}$ iménti forrásban pedig azt olvashattuk, hogy az innsbrucki táblákat "maratás és aranyozás” céljából küldték el neki. ${ }^{125}$ A nemrégiben restaurált innsbrucki táblákon az aranyozás laparannyal ${ }^{126}$ készült. A két kisebb lékai táblán az aranyozás még szintén jól kivehető, az itteni sírfelirat esetében azonban már csak a tábla jobb oldali sávjában maradt meg. A források a szükséges aranyfüst elküldéséről azonban nem tájékoztatnak, ami arra utal, hogy Bocskay ezt valószínüleg a saját költségén szerezte be. A technika elsajátításához számos nyomtatott segédlet állhatott a rendelkezésére.

Amikor a kalligráfus az 1560-as években síremlékfelirataihoz a kőmaratást alkalmazta, az eljárás még nem tekintett vissza hosszú múltra. ${ }^{127}$ Viszonylag gyors, olcsó és nem utolsósorban anyagánál fogva tartós volt, így előszeretettel alkalmazták a legkülönfélébb feliratos emlékek - címeres táblák, epitáfiumok, kalendáriumok, napórák, asztallapok stb. - kivitelezésére. Mivel leggyakrabban solnhofeni mészkövet használtak hozzá, elsőként ennek hazájában, Bajorországban vált népszerűvé a 16. század folyamán, de alkalmazása egészen a 19. századig kimutatható. ${ }^{128}$ Akik evvel foglalkoztak, az írás mesterségét általában tágabban müvelték: a vonatkozó forrásokban találunk iskolamestert, kántort, egyházi, városi, udvari írnokot. Bécsben működött például a landshuti Hans Ostermair (†1580), aki jellemzően városi megrendelésre dolgozott. ${ }^{129}$ Munkássága azt jelzi számunkra, hogy Bocskay idején Bécsben a kőmaratáshoz szükséges technikai háttér megteremtése lehetséges volt. Szintén ezt példázza két másik maratott felirat, amelyek az egykori Alsó-ausztriai Kamara épületének (Palais Niederösterreich) Hans Saphoy-féle átalakítása kapcsán készültek (156871). ${ }^{130}$ A kalligráfus a kőmaratást tehát egy másik, Bécsben müködő mesternél vagy autodidakta módon, nyomtatott kézikönyvek segítségével is elsa- 


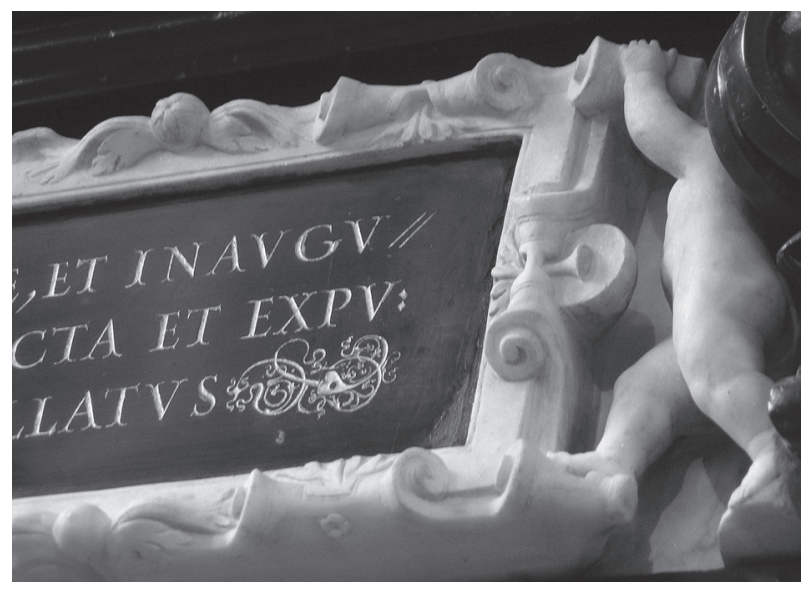

19. A 7. képaláirás részlete (A szerző felvétele, 2008)

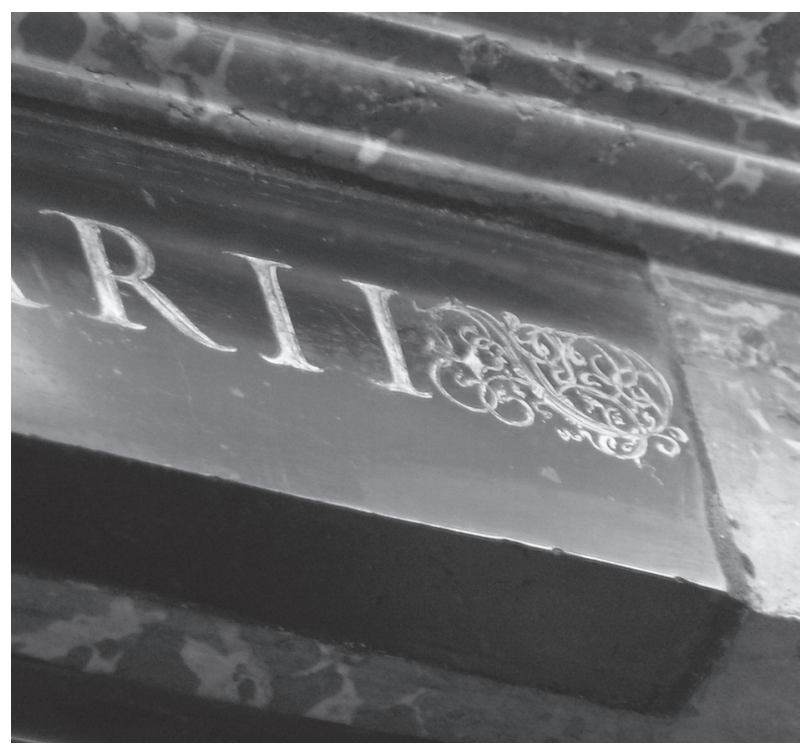

20. A sírfelirat lezárása (A szerző felvétele, 2008)

játíthatta. Utóbbi tűnik a valószínűbbnek. Sokféle írásmintakönyvet használt a kézirataihoz, bár ezekben a maratás leírása nem szerepelt. Azonban ekkoriban nagy számban voltak hozzáférhetők olyan segédletek is, amelyek a szükséges anyagokat és receptúrákat, valamint a folyamat leírását tartalmazták. ${ }^{131}$ Ugyanakkor az igen népszerü kőmaratás különleges státuszát jelzi, hogy 16-17. századi emlékeinek egy része Kunstkammerekben maradt fenn. Anyaguknál fogva ezek a táblák a "naturaliák” és a kalligrafikus ritkaságok közé egyaránt illeszkedtek. Például Ostermair két apró, feliratos kőlapja Ferdinánd főherceg ambrasi gyüjteményéből jutott később Bécsbe. ${ }^{132}$

Miután tehát Bocskay megkapta Innsbruckból az első márványlapokat (1563. október), ${ }^{133}$ a feliratozáshoz egy mühelyt kellett berendeznie. Ekkori bécsi tartózkodási helye azonban egyelőre nem ismert. A legközelebbi erre vonatkozó adat
1565 őszéről való. Bocskay egy Kanizsay Orsolyához írt leveléből ${ }^{134}$ arról értesülünk, hogy ekkor már a bécsi Nádasdy-házban lakott, amely a Hofburg szomszédságában, az Augustinergasse és a Dorotheergasse sarkán állt. ${ }^{135}$ Ugyanitt említette a lékai síremlék éppen készülő feliratait is, amelyből arra következtethetünk, hogy a mühely, amelyben mindkét síremlék feliratai készültek, Bocskay itteni szállásán volt. Két évvel később az I. Miksa-síremlék kőlapjai közül néhány darabot pótolni kellett, mivel azok a szállítás során eltörtek. Bocskay megadta, hogy ezeket Nádasdy Tamás bécsi házába vigyék, ${ }^{136}$ tehát ekkor a műhely még mindig itt lehetett. A forrásokból még annyi derül ki, hogy igen szükös helyen kellett dolgoznia. Legalábbis a késés miatt magyarázkodó kalligráfus 1567-ben arról számolt be II. Miksának, hogy harmincévnyi udvari szolgálata ellenére is csak egy kis helyiséget tud e célra fenntartani („qui a triginta annis serviendo unicam domunculam meis laboribus a majestatibus vestris non potuerim acquirere" ${ }^{137}$

Bocskay bizonyára maga döntött úgy, hogy a feliratok kivitelezéséhez a maratást választja. A véséssel szemben ezt mind a fizikai ráfordítás, mind a műhely helyigénye és felszereltsége szempontjából jóval könnyebben lehetett megoldani. Az eljárás ugyanakkor rendkívüli precizitást kívánt. Amikor a kalligráfus a feliratok kapcsán találkozott Ferdinánd főherceggel, maga is szubtilis munkaként jellemezte, és úgy vélte, a kőmaratás bizonyos alaposságot igényel (,,solches ain Subtilj Arbait, vnnd das Etzen in die Stain beÿ dem feuer mit sonndern Vleis beschechen mueß"). ${ }^{138}$ A technika valóban igen finom vonalak kialakítását tette lehetővé, a betűk cirkalmas díszítését vagy az egyéb ornamentikát szinte tollrajzra emlékeztető aprólékossággal tudta érzékeltetni. Bocskay élt is ennek a lehetőségével, amikor az I. Miksa-síremlék legtöbb képaláírását, valamint a körbefutó sírfeliratot arabeszkekkel zárta le (18-20., 27-28. kép). A díszítmények praktikusan a fennmaradó helyet töltötték ki. Egyúttal a kalligráfus virtuozitásának a bemutatására is alkalmasak voltak, mivel a megrendelt klasszikus antikva betűs feliratok nemigen engedtek teret az egyéni kifejezésmódnak.

Most folytassuk az innsbrucki feliratok keletkezéstörténetét. Bocskayról legközelebb 1564 októberében hallunk, aki ekkor sem küldött még kész lapokat Innsbruckba. Pedig Colin II. Miksától a képaláírások mihamarabbi befejezését kérte, hogy a kis táblákat végre beilleszthesse a keretükbe. ${ }^{139} 1565$ elejére sem változott a helyzet. Áprilisban Colin már a reliefek kétharmadát kivitelezte, és a feliratokhoz tartozó fehér márvány keretek is elkészültek, míg Bocskay tovább késett. Az innsbrucki veze- 
tés ezért ismét II. Miksához fordult, hogy próbálja elérni a kalligráfusnál a táblák gyors befejezését. ${ }^{140}$

Ahogyan említettük, Ferdinánd főherceg 1565 májusában személyes megbeszélést kezdeményezett a munka állásáról Bocskayval a feliratok immár másfél éves csúszása miatt. ${ }^{141}$ Bécsből Innsbruckba küldött beszámolója szerint a kalligráfus már a táblák majdnem felét elkészítette. Csekélyke haladását tehát avval magyarázta, hogy finom munkáról van szó, amely alaposságot igényel („Das Er aber dieselben bißherr nit gar Verferttigt vnnd Zuegeschickt, das seÿ die Vrsach, solches ain Subtilj Arbait, vnnd das Etzen in die Stain beÿ dem feuer mit sonndern Vleis beschechen mueß."). Végül arra tett ígéretet, hogy a fennmaradó táblákat igyekszik majd szorgalmasan befejezni. Közben Innsbruckban Colin a reliefek faragásával rendkívül gyors tempóban haladt. 1565 augusztusában már 22 darabnál tartott, viszont továbbra sem érkeztek meg hozzá a feliratok. ${ }^{142}$ Decemberben kezdett neki az utolsó dombormünek, ${ }^{143}$ amellyel 1566 márciusára lett kész. ${ }^{144}$ A szobrász a reliefeket tarthatta az egész kompozíción belül a legjelentősebb alkotásának, mivel a tumbán található szignatúrájára ez az évszám került (21. kép).

Eddig a pontig tehát a feliratokról csupán annyi konkrét információval rendelkezünk, hogy Bocskay

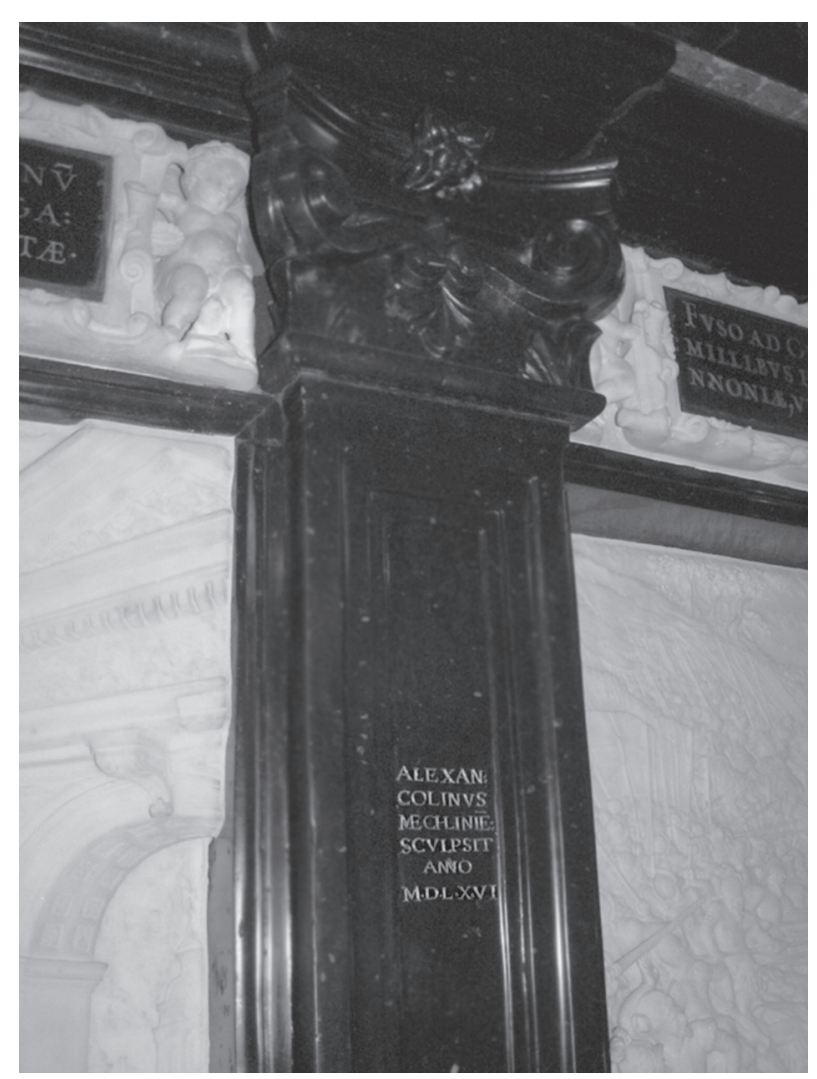

21. Alexander Colin szignatúrája a tumba északi oldalán (A szerzó felvétele, 2007) saját állítása szerint 1565 májusában a tábláknak már majdnem a felével készen volt. Ennek ellenére a források szerint nem küldött 1566-ban sem kész darabokat a síremlék helyszínére. Legközelebb egy újabb év elteltével, 1567 tavaszán hallunk a munkáról, amikor az innsbrucki vezetés és II. Miksa egyaránt a munka gyors befejezésére próbálja majd rávenni Bocskayt. A kalligráfus két válaszlevele különösen fontos számunkra, mert végre részletesen értesülünk belőlük a kivitelezés állásáról, és az is kiderül, hogy valójában két feladattal bízták meg: a képaláírásokon kívül a sírfeliratot is vele készíttették el.

1567 márciusában tehát az innsbrucki vezetés megkérte II. Miksát, hogy próbálja ismét sürgetni Bocskayt. ${ }^{145}$ Úgy fogalmaztak, mivel Colin jó ideje befejezte a reliefeket, a feliratok késése miatt most már a tumba felállítása hiúsul meg. Abban igazuk volt, hogy a reliefek az előző év elején tényleg elkészültek, viszont a sírláda összeállítását, még ha megkapták volna a feliratokat, akkor sem tudták volna rögtön elvégezni. A reliefeket tagoló fekete keretek átalakítása miatt ugyanis a tumba még csak félkész állapotban volt, felállítása még további hét évet vett igénybe. Közben ugyanis úgy döntöttek, hogy a négy erény bronzfigurája nem a sarkokra, hanem a fedélre kerül majd. Ezért a feketemárvány pilaszterek és keretek egy részét újra kellett faragni. ${ }^{146} \mathrm{~A}$ változtatás jól látszik például azon, ahogyan az új, szélesebb pilaszterek fejezetei a feliratok fehér keretének a puttóit kitakarják (21-22. kép).

A fenti vélemény mindenesetre valamiképpen eljutott Bocskayhoz, aki néhány nap múlva egy hosszú, latin nyelvü levélben reagált az innsbruckiak sürgetésére. ${ }^{147}$ Mint írta, összesen 40 feketemárvány táblát kapott kézhez, azonban közülük 5 törött volt. Emiatt több alkalommal írt Innsbruckba, nagy csodálkozására azonban ennek a császári ügynek a befejezésével kapcsolatos sürgetésére választ nem kapott. Ráadásul éjjel nappal dolgozott a szövegek befejezésén (,ut opus ipsum, quod dies et noctesque uerso, iam tandem ad fidem perducam, nec iam aliquid aliud desiderari videtur"), és még udvari titkári teendőit is szüneteltette miatta (,,interim me supersedere ab officio secretarii”). Ezért kéri, a törött táblák pótlását küldjék el neki Bécsbe, az említett Nádasdy-házba, hogy a munkát be tudja végre egyszer és mindenkorra (,,simul et semel”) fejezni, és az egészet el tudja nekik juttatni.

Leveléhez az áttekinthetőség végett egy vázlatot is mellékelt, amelyet szintén másolatból ismerünk. ${ }^{148}$ Ez csak a sírfelirat tábláit mutatta, amelyeket a felülnézetből lerajzolt tumbán, az egyes lapok méretének érzékeltetése nélkül ábrázolt. Mint írta, a sírfelirat („haubt tittl oder epitaphium”) egymás 


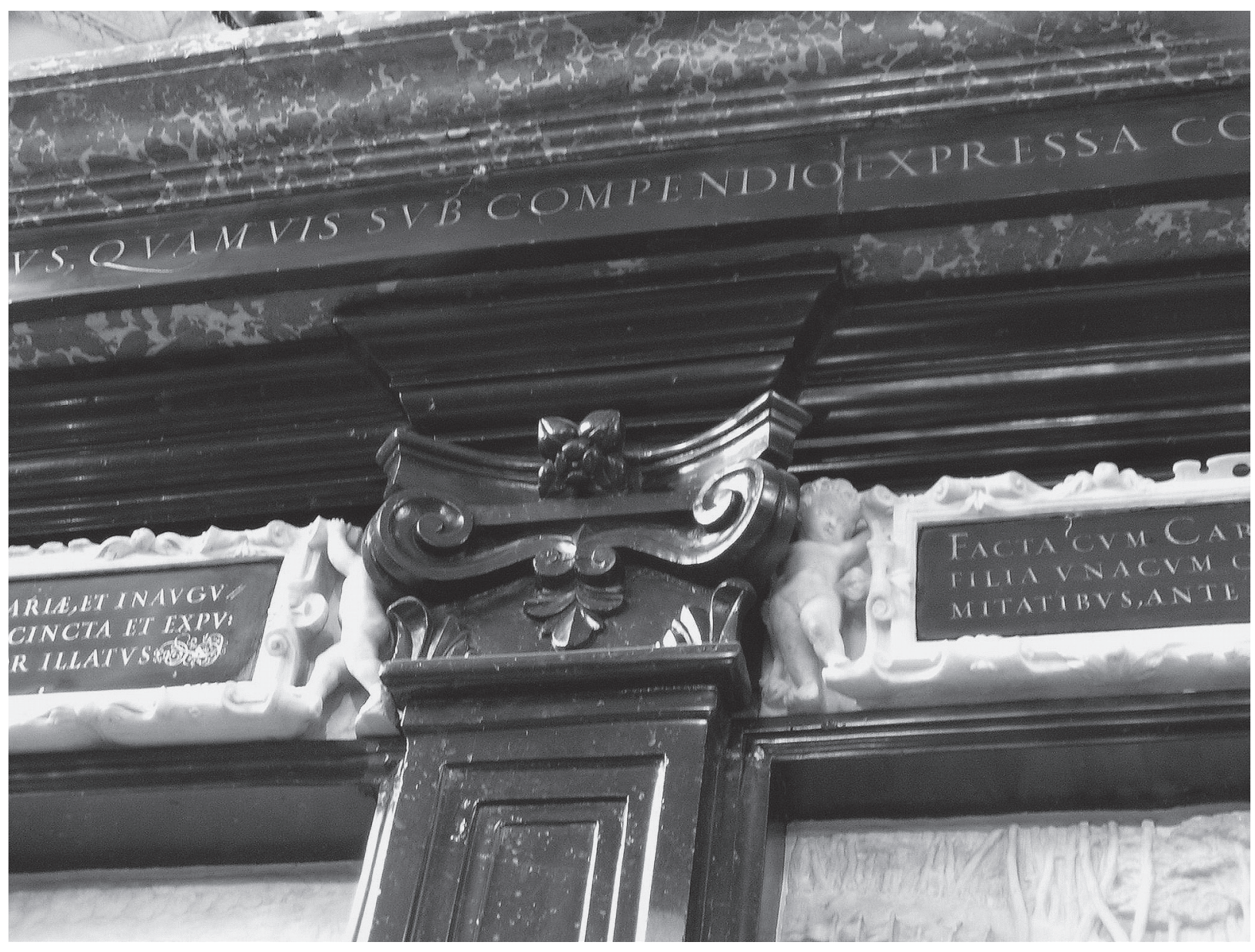

22. A tumba déli oldalának részlete (A szerző felvétele, 2008)

után következő részeit 1-18-ig számokkal látta el, és ezekből az 1., 2., 3. és 14. hiányzik („deest”). Az ábra közepére helyezett latin megjegyzésében pedig utalt a 24-ből még hiányzó 5 képaláírás táblájára. Vagyis ekkorra 19 képaláírást befejezett és 5-öt nem, továbbá készen volt már a sírfelirat 14 darabjával, ez összesen 33. Öt törött lapot említett, ezzel együtt ez 38 darab, tehát a 40 elküldöttből még két ép lapnak kellett volna maradnia nála. A későbbi forrásokból azonban az derül ki, hogy ennek ellenére az innsbruckiaknak még 5 képaláírást és a sírfeliratból még 4 hiányzó lapot kellett eljuttatniuk neki.

II. Miksa néhány nappal később szintén figyelmeztette a kalligráfust a síremléket díszítendő 24 (sic!) felirat mielőbbi befejezésére. ${ }^{149}$ Bocskay ezért 1567. ápr. 3-án egy igényes formátumban megírt, terjedelmes latin levélben a fentiekről a császárt is tájékoztatta. ${ }^{150} \mathrm{Az}$ arany felirattal díszített táblák ügyében („Ut eius [...] conscriberem, uel pocius insculperem, characteresq[ue] ipsos auro adornarem") írt beszámolójában valamivel bővebben részletezte a munkát lassító körülményeket. Azt írta, a feliratokon a császár elutazása óta folya- matosan dolgozik, bár beteg volt, és kellemetlen családi események („,uxoris et familiæ meæ uariæ incommoditates") hátráltatták, továbbá az udvarban betöltött három évtizednyi hűséges szolgálata ellenére csak egy kis műhelyt tud fenntartani (,qui a triginta annis serviendo unicam domunculam meis laboribus a majestatibus vestris non potuerim acquirere"), valamint titkári teendői is teljes embert kívánnak („officium secretar[ium], quo fungor in expedientis alÿs emergentibus necessarÿs rebus, Opus vero hoc laboriosum requirat integrum hominem"). Továbbá megismételte, hogy a 24 helyett Innsbruckból 40 feketemárvány táblát kapott kézhez, ebből 5 szállítás közben eltört, és emiatt nem tudta még a hiányzókat elkészíteni. Leveléhez egy újabb rajzot csatolt (23. kép). Az ábrán a „Caput monumenti" felirattal látta el a bejárat felé eső oldalt, ahol a sírfelirat kezdődik, bejelölte a hiányzó darabjait (1-3., 14. „deest”), valamint az ábra közepén megint utalt a még hiányzó 5 képaláírásra. A kapott választ a tervrajzzal együtt II. Miksa azon nyomban Innsbruckba továbbította, ${ }^{151}$ ezért található ma a rajz az itteni levéltárban. 
A hiányzó lapokat végül egy hónappal később pótolták, és erről az innsbruckiak II. Miksát ${ }^{152}$ és Bocskayt ${ }^{153}$ is értesítették. Beszámolójuk szerint a kért táblákat a helyszínen rendelkezésre álló maradék feketemárvány törmelékéből tudták csak előállítani. Ezért a sírfelirat kért 4 lapját 7 kisebb darabban kivitelezték (az 1-3. számút 5, a 14. számút 2 részben). Ezenkívül elkészítettek még 5 azonos nagyságú, képaláírásnak szánt táblát is, amelyeket „H”, azaz „Historia” megjelöléssel láttak el.

Érdemes most összevetni a fenti forrásokat a síremléken található táblák mai számával. A 24 képaláírás mennyisége a reliefek száma alapján adott volt. Viszont a Bocskay által 18 részesnek lerajzolt sírfelirat (23. kép) ma több darabból áll. A két vázlaton még oldalanként $3+5+4+6(=18)$ darabot számlált, jelenleg viszont a tumbán $5+6+5+8$ (=24) tábla található. Az imént említettük, hogy a pótláskor a meglévő 14 darabhoz a hiányzó 4 helyett további 7 érkezett. Ez eddig összesen 21, azonban még további 3 hiányzik a 24-hez. Erre egy későbbi forrás ad magyarázatot. A kész táblák közül néhány - ezek szerint 3 - a Linz és Kufstein közötti hajóúton eltörött, ${ }^{154}$ így ezek több darabban érkeztek Innsbruckba. A lapok méretéből kiindulva valószínűleg a három legkisebb, mindössze $20-25 \mathrm{~cm}$ széles tábláról (a 12., 18., 23. darab) lehetett szó.

A feliratok kivitelezése a hiányzó kőlapok pótlása ellenére sem haladt. Az innsbrucki vezetésnek a kész táblákra egy újabb évet kellett még várnia. 1568 márciusából ismerünk egy innen kelt, újabb sürgető levelet, amely a Kamara egyik bécsi megbízottjának szólt, akinek személyesen kellett felkeresnie a feliratok ügyében Bocskayt. ${ }^{155}$ Április végén már arról értesítették Blasius Khuen von Belasyt, a Felső-ausztriai Udvari Tanács vezetőjét, hogy a felkérés Bécsben sikerrel járt. ${ }^{156}$ Maga Khuen von Belasy május 5-én számolt be a feliratok elkészültéról ${ }^{157}$ és két nappal később kiállították azok szállítólevelét is. ${ }^{158}$ Bocskayt pedig azonnal utasították, hogy adja át Ferdinánd főherceg embereinek a táblákat. ${ }^{159}$

A Felső-ausztriai Kamara hivatalosan 1568. május 11-én jelentette a főhercegnek a munka befejezését. ${ }^{160}$ Hogy Bocskay az elkészült darabokat miért nem küldte el már a korábbi évek folyamán a síremlék helyszínére, az az innsbruckiak következő megjegyzéséből derül ki. Azt írták, hogy a kész feliratokat a királyi titkár csak a neki járó 400 tallér kifizetése fejében lesz hajlandó átadni. Vagyis Bocskay egyfajta biztosítékként a lehető legtovább magánál tartotta a táblákat, hogy megkapja a neki ígért összeget. A Kamara azonban sokallta a 400 tallért a rossz, átlagos és díszítetlen latin feliratokért (,ist es nun ain schlechte gemaine Lateinische schrifft mit grossen Puechstaben, o[h]n[e] alle Zier [...] Vnd dieweil das ain allgemaines werckh"), ezért azt javasolták a főhercegnek és a császárnak, hogy kevesebbet fizessenek értük.

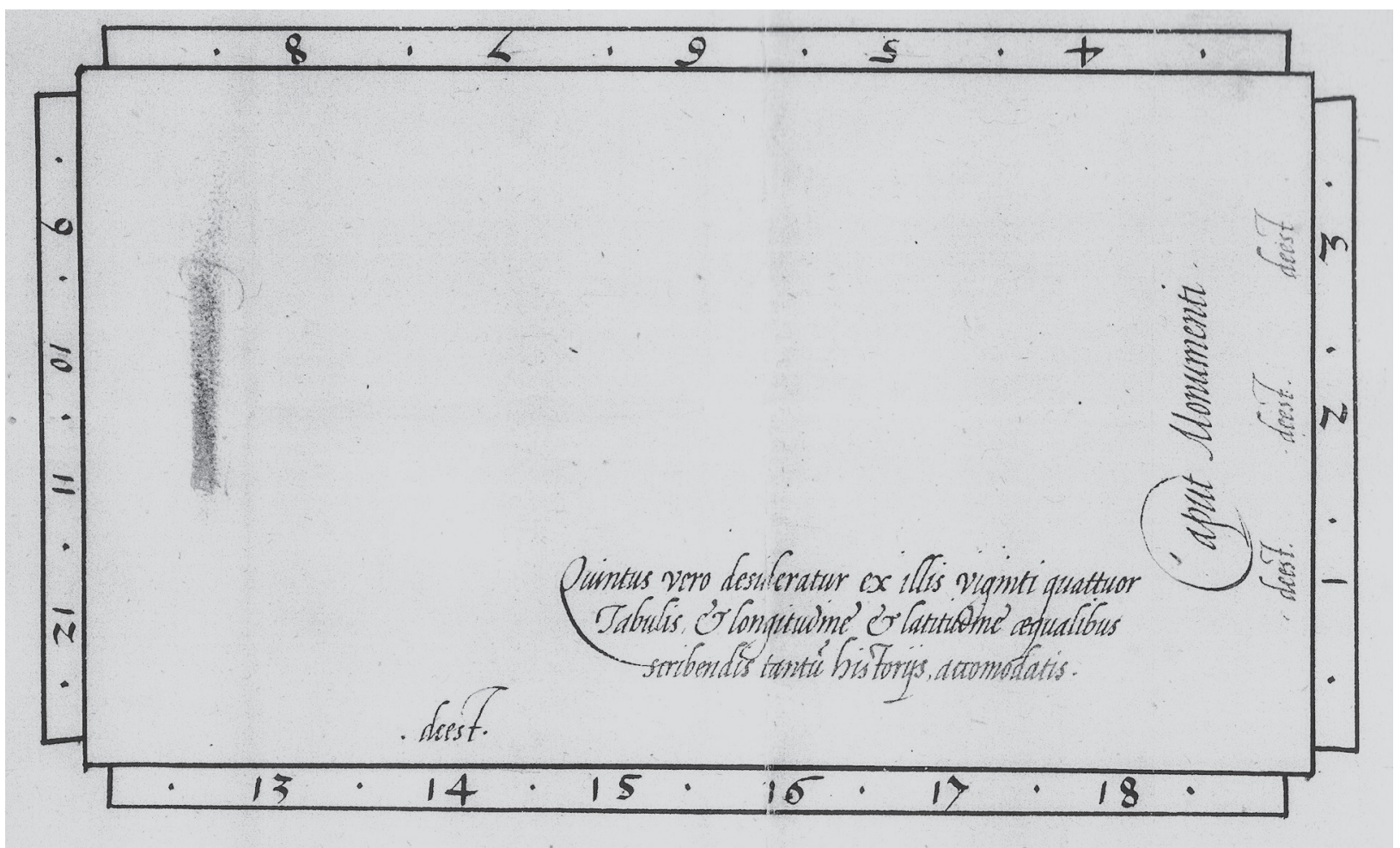

23. Bocskay György vázlata a sírfelirat tábláiról (Tiroles Landesarchiv, Innsbruck, Kunstsachen I., K 1453, Pos. IV., 399r) 
Az említett Blasius Khuen von Belasy néhány nappal késóbb személyesen találkozott ez ügyben Bocskayval. Innsbruckba küldött levelében ${ }^{161}$ már nincs utalás a szövegek rossz minőségére, szerinte a magyar udvari titkár a szorgosan és helyesen („,vleissig unnd gerecht”) kivitelezett táblákkal rászolgált a fizetésére. A tanácsos erre Ferdinánd főherceg részéről az elhunyt esztergomi érsek - azaz Oláh Miklós - hagyatékának a terhére vállalt garanciát. Ugyanakkor ő is azt javasolta, hogy a titkár által követelt 400 tallér helyett kevesebbet, nevezetesen a felét, 200-at utaljanak ki neki. Ha pedig továbbra sem lesz elégedett, hivatkozzanak csak arra, hogy a császártól annak alkalmazottjaként kapta egykor a megbízást, így e minőségében amúgy is kap fizetést. Bocskay udvari pályafutása alatt végig kénytelen volt a neki járó összegek késedelme miatt az udvarhoz beadványokat intézni. Ezért érthető volt, hogy a kifizetés előtt egyetlen kész feliratot sem akart kiengedni a kezéből. Végül mégis belement az összeg megfelezésébe: június elején arról értesítették Ferdinánd főherceget, hogy az udvari titkár hajlandó a táblákat átadni és Innsbruckba szállíttatni. ${ }^{162}$

A 200 tallér kifizetésére Ferdinánd főherceg június 8-án adott utasítást. ${ }^{163}$ A számadáskönyvi bejegyzés szerint az összeget valóban Oláh Miklós hagyatékának a főhercegre eső részéből rendezték. ${ }^{164}$ $\mathrm{Az}$ innsbrucki vezetés másfél hónappal később rendelte el, hogy a 200 tallérról szóló elismervényt juttassák el az udvari titkárnak Bécsbe. ${ }^{165}$ Bocskay az összeget az itteni udvaron keresztül, valamikor ezután kapta meg. Az innsbruckiak viszont csak jóval később utalták át Bécsnek a tartozásukat. Ennek átvételéről és lekönyveléséről II. Miksa David Haag számadásmesternek 1570-ben küldött utasítást. ${ }^{166}$ Az október 24-én kelt irat szerint az elismervény fejében korábban már kifizették Bocskaynak a feliratos táblák maratásáért és aranyozásáért járó 200 tallért (azaz 226 Ft 40 krajcárt/Gulden).

A 24 képaláírás és a sírfelirat kivitelezéséért tehát 400 tallért (kb. $450 \mathrm{Ft} / G u l d e n)$ ígértek, végül Bocskay ennek a felét (kb. 226 Ft/Gulden) kapta meg. Az összeg, a megfelezése ellenére a saját éves bevételei szempontjából még mindig jelentős summa volt. ${ }^{167}$ Ugyanakkor a mintegy 65000 Guldent $^{168}$ felemésztő együttes teljes költségén belül elenyészőnek számított. A tumba szobrászati részének a munkadíjaihoz képest pedig szintén csekély volt, elég csak azt említenünk, hogy az Abel fivérek egyetlen relief kifaragásáért kaptak közel ugyanennyit, 240 Guldent. ${ }^{169}$

Mindeközben elkezdték Bécsben szervezni a kész táblák Innsbruckba szállítását. A Felső-ausztriai Kamara másolati könyveiben (Kopialbücher) 1568-ból erre vonatkozóan júliusban ${ }^{170}$ és augusz- tusban $^{171}$ találhatók az első utalások. Bár Bocskay júniusban átadta a táblákat, eszerint a lapokat tartalmazó három láda nyár végén még mindig Bécsben az udvari számadásmesternél, David Haagnál volt. A levelekben őszre tervezték a szállítást, azonban csak nagy nehezen találták meg a módját, hogy a törékeny táblákat vízi úton küldjék el. Végül Bécsből október végén indult el a szállítmány Linzen keresztül Innsbruck felé. ${ }^{172}$ Egy december végi levél ${ }^{173}$ szerint sikerült találniuk egy hajót, amely Linzből Kufsteinig jutott el. A kapitány azonban arról számolt be, hogy néhány tábla nem volt jól becsomagolva és ezért eltörött. Már említettük, hogy ez eredményezhette, hogy a forrásokban 18, majd a pótlások után 21 darabos sírfelirat ma 24 részből áll. A három láda Innsbruckba kerülése még egy kis időt bizonyára igénybe vett, a kész feliratok így valamikor 1568-1569 fordulóján kerülhettek a síremlék helyszínére. A tumbát végül a korábban említett változtatásoknak köszönhetően 1574-ben állították fel. ${ }^{174}$ Alexander Colin ekkor már a fedlap öt nagyméretü bronzszobrán dolgozott, amelyek kivitelezése, valamint a sírládát övező kovácsoltvas rács készítése áthúzódott az 1580-as évekre. A teljes kompozíció összeállítására az első tervek megszületése után közel 90 évvel, 1589-ben került sor.

A forrásokat áttekintve felvetődik a kérdés, vajon miért tartott Bocskaynak öt évig, hogy az I. Miksasíremlék tábláit elkészítse, mikor maga a technika meglehetősen gyors kivitelezést tett volna lehetővé. Hiába állt elő például 1566-ban az a helyzet, hogy Colin a hiányzó reliefeket hamarabb befejezte, mint a kalligráfus a hozzájuk tartozó feliratokat, Bocskay még további két évig halogatta a feladatot. Az egyik magyarázat valószínúleg a maratás technikájában keresendő, amelynek magabiztos elsajátításához és egyenletesen jó minőséget eredményező alkalmazásához a vártnál több időre volt szüksége. Mint láttuk, leveleiben számos hátráltató tényezőre is hivatkozott. Ugyanakkor 1563-68 között nem volt annyi kalligráfusi feladata, amely ténylegesen lassíthatta volna a kivitelezést. Az állandó innsbrucki és bécsi sürgetésekből inkább az látszik kirajzolódni, hogy a kezdetben nagy presztízst és jó fizetést ígérő feladat egyre inkább nyüggé vált a számára. Végül mindaddig halogatta a befejezést, amíg már kénytelen volt eleget tenni az egyre erösebb hangú innsbrucki és bécsi felszólításoknak.

\section{Az I. Miksa-síremlék all'antica feliratai}

A templom déli tájolású, a tumba a főhajó közepén, annak tengelyében áll (9-10. kép). Két egymás fölötti sorban tehát 24 relief található rajta, a hossz- 
oldalakon 8-8, a rövidebb oldalakon 4-4. A ciklus az északi, rövidebb oldal felső sorában kezdődik, amely a templom fóportálján át érkezők felé esik. $\mathrm{Az}$ óramutatóval ellentétes irányban halad, körbeérve az alsó sorban folytatódik a keleti hosszoldalig. A 24 jelenetből álló sorozat I. Miksa császár életének kiemelt eseményeit dolgozza fel 1477-től (genti esküvője Burgundiai Máriával) 1516-ig (Verona ostroma). Egy teljes és két félkész relief (1., 4., 23.) még Arnold és Berhard Abel munkája, a többit Alexander Colin és műhelye kivitelezte. A domborművek anyaga fehér carrarai márvány, ${ }^{175}$ méretük $45 \times 80 \mathrm{~cm}$. Feketemárvány keretbe ágyazódnak, amelynek lábazati zónája, valamint zárópárkánya gazdagon profilozott. Az egymás fölött elhelyezett dombormúpárokat korinthoszi pilaszterek tagolják, amelyek törzse tükörrel többszörösen mélyített (21-22. kép).

Bocskay György 24 képaláírása az egyes reliefek fölé került (24-25. kép). Valamennyi feketemárvány tábla egy második, fehérmárvány ${ }^{176}$ keretet kapott (26. kép). Közülük hat darab még az Abel fivérektől származik, a továbbiak Colin múhelyében készültek. ${ }^{177} \mathrm{~A}$ képaláírások táblái a reliefek méretéhez

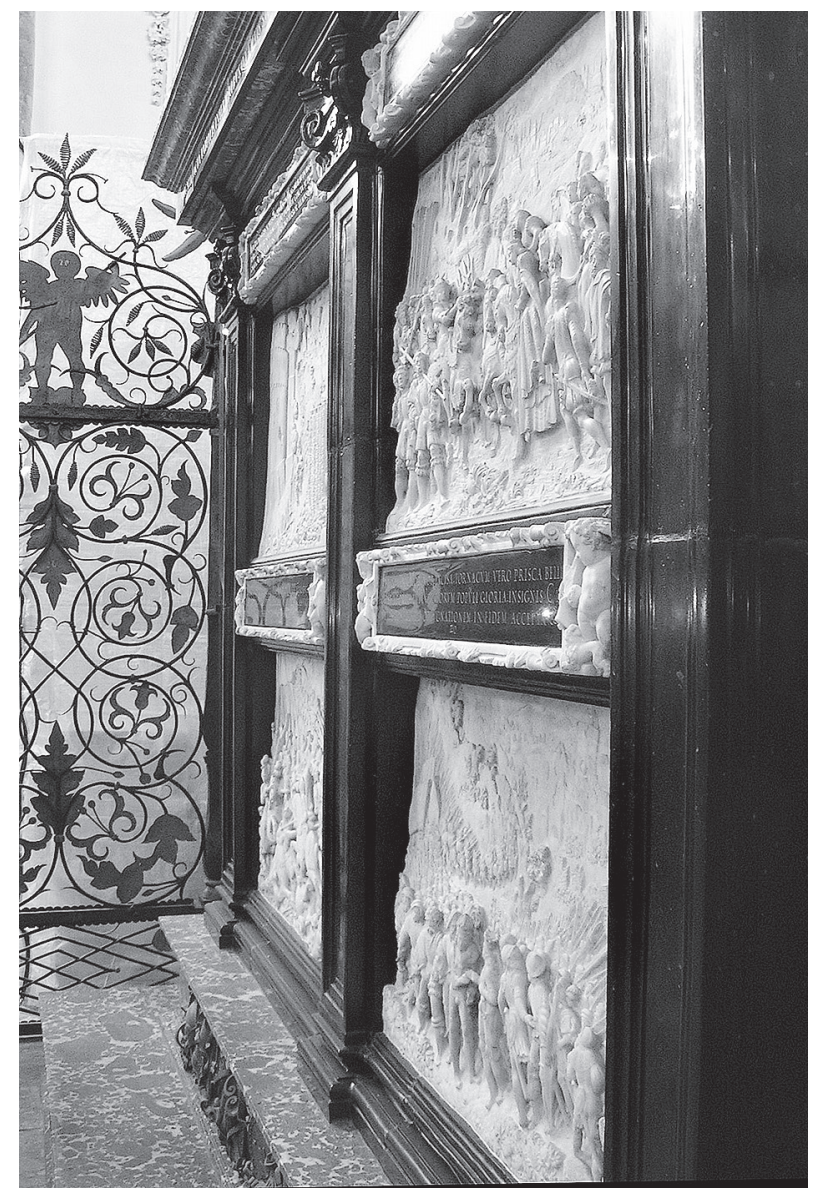

24. A tumba déli oldala (A szerző felvétele, 2008) igazodnak, különálló fehér keretük a dombormüveknél mindössze néhány centiméterrel szélesebb. A kereteket gazdagon tekeredő Rollwerk-motívum alkotja, amelyet levelek és gyümölcsök egészítenek ki. A feliratokat kétoldalt egy-egy álló puttó tartja, amelyeket változó attribútumok (pl. bőségszaru, koponya, lúd, oroszlán) kísérnek. A figurális dekoráción belül a fekete tabulákat egy további, keskeny profilozott sáv veszi körül (27-28. kép).

A feliratos táblák mérete a helyszíni felmérés alapján átlagosan 9,6×67 cm, minden oldalukon kb. 0,5 cm-es csiszolatlan perem található. Vastagságuk kb. $2,7 \mathrm{~cm} \cdot{ }^{178} \mathrm{~A}$ táblák anyaga fekete márvány, amely a Garda-tó vidékéről származik. ${ }^{179}$ A reliefeket tagoló pilaszterek és profilozott keret, valamint a sírfelirat táblái szintén ebből készültek.

A domborművekhez tartozó táblákra tehát Seld alkancellár latin prózában írt képaláírásai kerültek (l. Függelék I/a). A klasszikus kapitális feliratokat Bocskay maratással kivitelezte, majd laparannyal aranyozta. A szövegek mindegyik táblán három sorba rendeződnek. Az alsó, illetve felső sor a tábla hosszanti szélétől egyenlő távolságra helyezkedik el. A sorok egymás közti távolsága valamivel kisebb, végig egyenletes. A kalligráfus az elrendezésüket a tábla széléhez képest igen kiegyensúlyozottan oldotta meg (28. kép). A maratott feliratok mély-

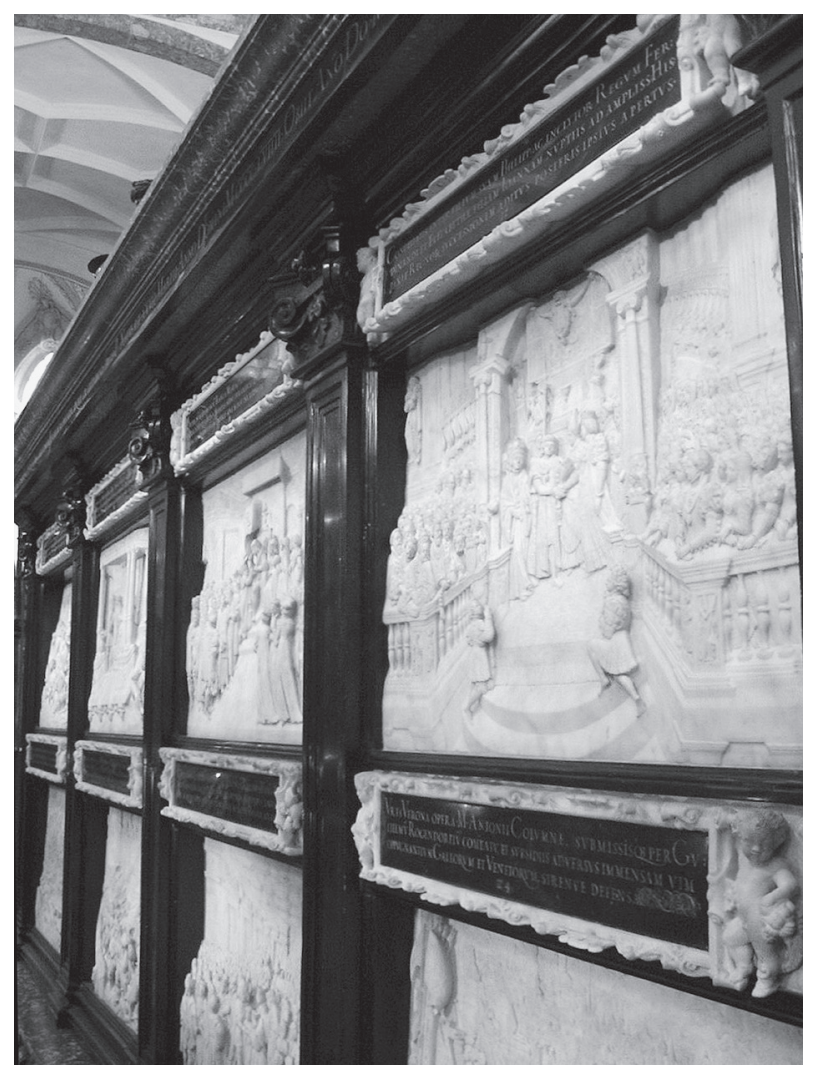

25. A tumba keleti oldala (A szerző felvétele, 2007) 
sége mindössze $\mathrm{kb} .1 \mathrm{~mm}$. A betünagyság néhány centiméter, a nagybetűk magassága 1,9-2,4 cm, a kisbetűké pedig 1-1,2 cm között mozog. A szárak vastagsága előbbieknél átlagosan 2-3, utóbbiaknál 1-2 mm.

A feliratok kivitelezése nem egyforma, vannak valamivel robusztusabb, illetve finomabb felépítésü betűkből álló szövegek. A 2-5., 9-12. táblán vastagabb (18. kép), a többin vékonyabb a betűk szára (28. kép), amely valószínúleg a munka egy-egy fázisában készült táblákat jelzi. Úgy tűnik, Bocskay a sor elején álló képaláírásokkal kezdett, majd eközben jött rá, hogyan lehet a szövegeket egyre finomabban kialakítani. E szempontból legsikerültebbek a ciklus végén található, egészen légies betűkből álló feliratok. Az 1., 6-8. tábla talán újra is készült, mivel ezek a sorozat második felének a színvonalához állnak közelebb (19. kép). A befejezés sietségére utal, hogy az első lapokhoz hasonló vastagabb betük egy-egy esetben a 21-24. darabon is megjelennek (30. kép).

Korábban említettük, hogy ahol az adott sor nem töltötte ki a tábla teljes szélességét, Bocskay a szöveg végére egy-egy finom vonalvezetésű arabeszket helyezett el. A díszítmények között nincs két egyforma, méretük a rendelkezésre álló hely függvényében változik (2., 3., 4., 6., 7., 8., 9., 10., 11., 14., 15., 19., 20., 22., 23., 24. tábla, 18-20., 27-28. kép).

A háromsoros szöveg alján, középen 1-24-ig arab számok találhatók (30. kép), amelyek a betükhöz képest gyengébb kvalitást képviselnek. A helyszíni vizsgálat alapján a felirathoz viszonyítva némely esetben más mélységben helyezkednek el. A számjegyek aranyozása laparany, amelynek az alapozása a restaurátorok szerint a feliratok két rétegével szemben csak egyrétegü. ${ }^{180}$ Mindezek alapján a számozás nem a kalligráfustól származik, hanem valamikor utólag került a szövegek alá.

A tumbára került sírfeliratot szintén Seld alkancellár fogalmazta (l. Függelék I/b). A terjedelmes szöveg klasszikus antikva kapitálissal íródott, amelyet ugyancsak Bocskay maratott, majd aranyozott. A sírfelirat tehát 24 táblából áll össze. A reliefciklus irányát követi: a bejárat felé eső északi, rövidebb oldalon kezdődik, és az óramutatóval ellentétes irányban halad a keleti hosszoldal végéig (29. kép). A feliratos táblák a képaláírásokkal azonos fekete márványból vannak. A szöveget a tumba koronázópárkányának frízébe illesztették, amelynek anyaga vörös-fehér Rotscheck. A fekete szalag ezen fut körbe, de egyik oldalon sem tölti ki annak teljes szélességét.

A sírfelirat tábláinak vastagsága átlagosan 2,42,7 cm. Ez alól kivételt képez a 11-16. darab, amelyek mindössze 1,5 cm-esek. Magasságuk egysége-

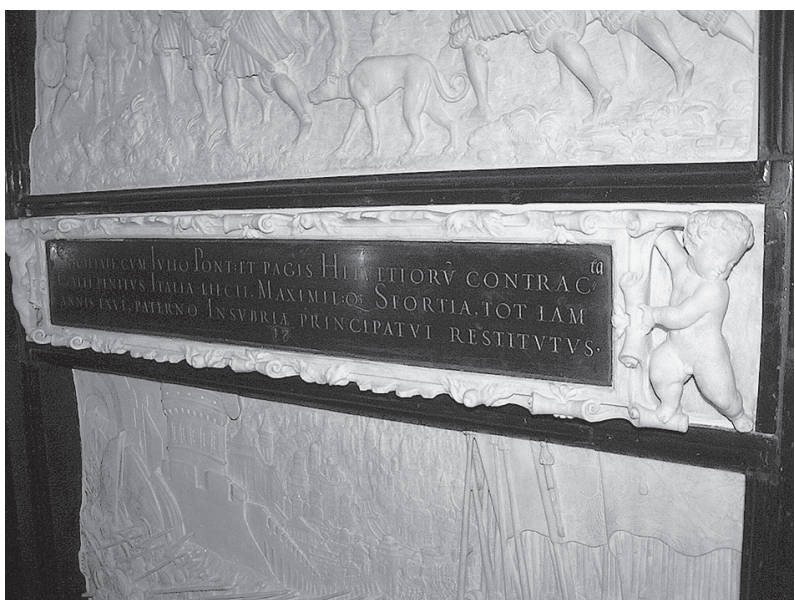

26. A 18. képaláírás kerete (A szerző felvétele, 2007)

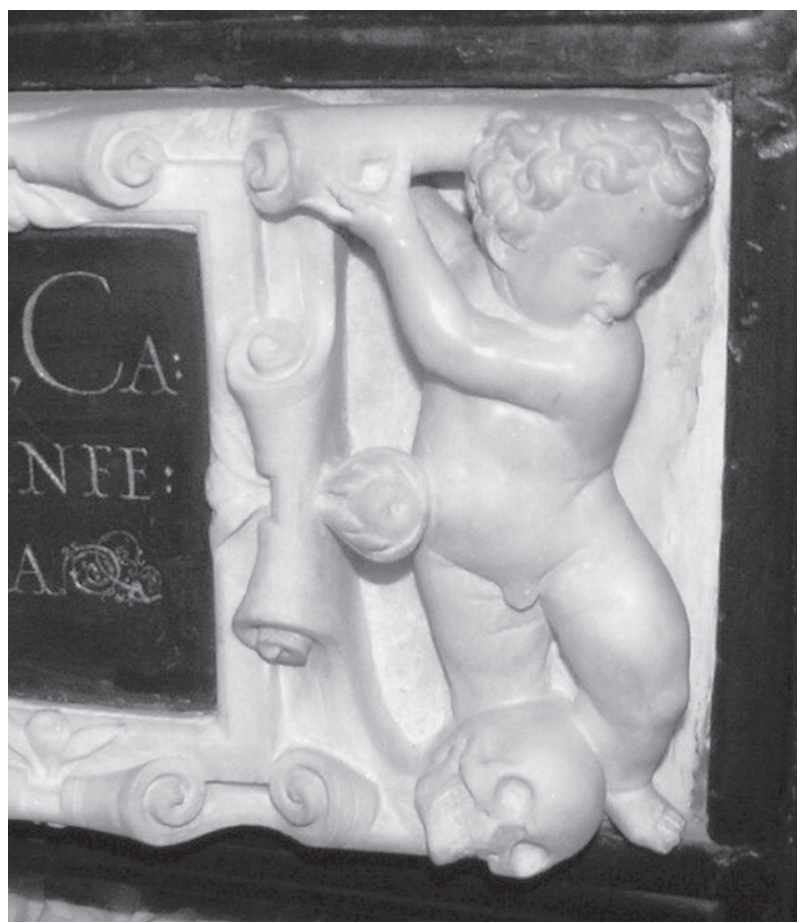

27. A 15. képaláirás keretének részlete (A szerző felvétele, 2007)

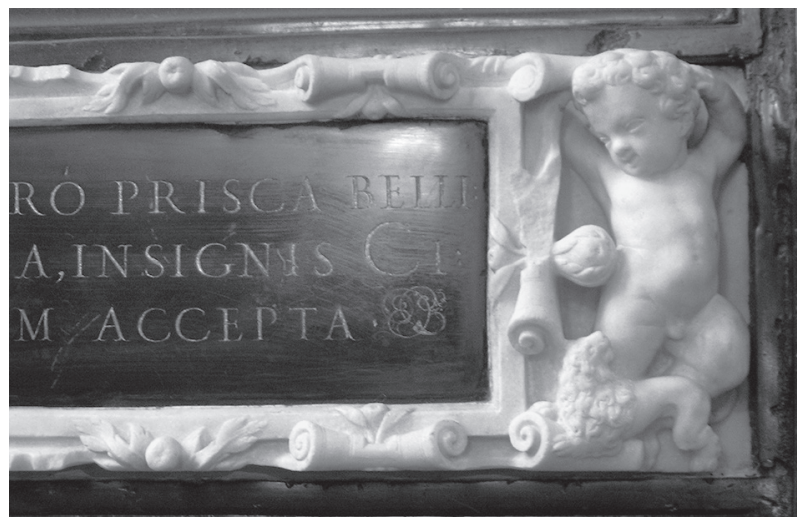

28. A 20. képaláirás részlete (A szerző felvétele, 2008) 


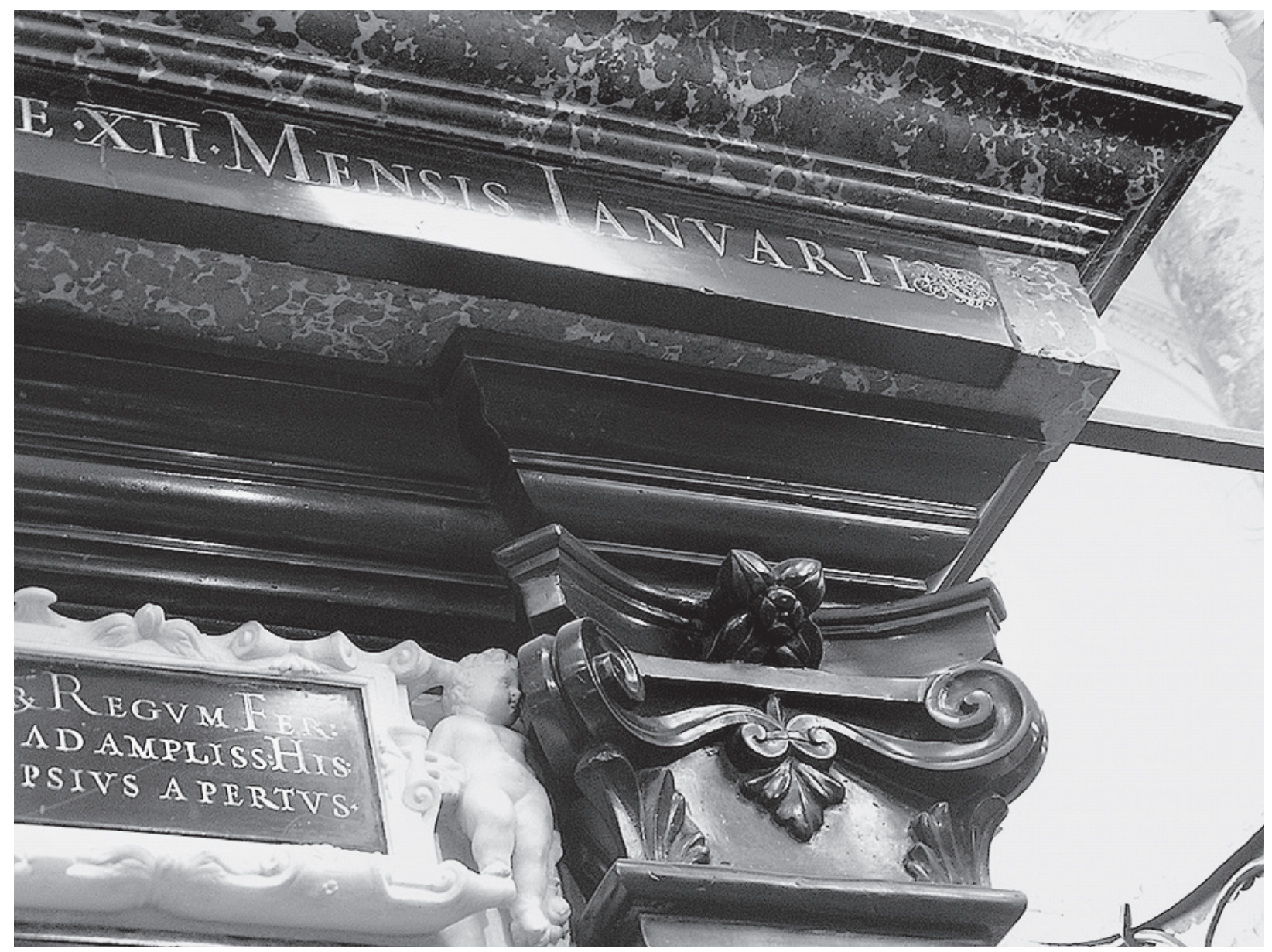

29. A sírfelirat vége a keleti oldalon (A szerző felvétele, 2008)

sen $7,7 \mathrm{~cm}$, a szélességük viszont igen különbözö, 20,5-87 cm között mozog. Ez az egyenetlenség, mint erre utaltunk, az Innsbruck és Bécs közötti szállítás során megsérült lapokból adódott. A szöveg egy sorba rendeződik, valamivel nagyobb távolságban helyezkedik el a tábla alsó szélétől, mint a felsőtől. Bocskay az egyes szavakat és betüket egyenletesen helyezte el, a betük, illetve a szavak közti távolság a sok, különböző hosszúságú tábla összeillesztése ellenére végig azonos marad. A nagybetűk 4-4,3,

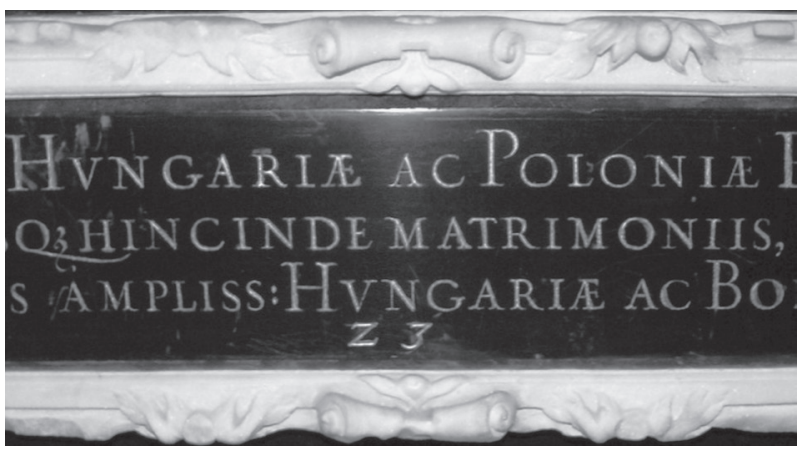

30. A 23. képaláirás részlete (A szerző felvétele, 2007) a kisbetük 2,4-2,5 cm-esek, a szárak vastagsága 3-7 mm között mozog.

Végezetül vizsgáljuk meg, hogy a kalligráfus a feliratokhoz milyen mintákat használt. A római eredetű nagybetűs antikva újrafelfedezése Itáliában a korai humanizmus idején, az ókori szövegek feltárása kapcsán kezdődött (ún. korai klasszikus kapitális). ${ }^{181}$ A Bocskaynál is megjelenő, ún. klasszikus kapitálist a 15. század közepe tájától használták. A négyzetbe írt betükonstrukciókat Vitruvius nyomán az oszloprendek mintájára egyetlen alapegységből, a legszélesebb ponton mért szárvastagságból vezették le, amelynek a négyzet oldalához viszonyított ideális aránya 1:9 vagy 1:10 volt. ${ }^{182}$ A betütípust Alberti már az épületek egyik díszítőelemeként tárgyalta (De re aedificatoria Liber VIII., 1. kiad.: Firenze 1485). ${ }^{183}$ Közben egyre gyakrabban tünt fel az „atmoszférateremtö"184 nagybetüs antikva kéziratokban, nyomtatványokban és a Quattrocento vezető mestereinek müvein. ${ }^{185}$

A klasszikus kapitális a 16. századra egész Európában rendkívül kedvelt betütípussá vált. Szerkesztését vagy legalábbis betűit az itáliai és 
Alpokon túli nyomtatott írásmintakönyvek is felvették a repertoárjukba. Ezek közül Bocskay számos segédletet használt (Ludovico degli Arrighi, Giovanbattista Palatino, Vespasiano Amphiareo, id. Johann Neudörffer nyomán Wolfgang Fugger). Például Arrighi és Palatino kapitálisait az innsbrucki feliratok előzményének szánt írásmintakönyvében szerepeltette („G" $\mathrm{G}^{\prime}$ 15. kép, „R", „ $\mathrm{M}^{\prime}$, „, $\mathrm{P}$ ”, 16. kép). $\mathrm{Ha}$ az általa ismert nyomtatott betükonstrukciók hatását a síremlékfeliratain próbáljuk kimutatni, néhány jellegzetességre felfigyelhetünk. A betük megformálása mind az innsbrucki, mind az alábbiakban bemutatandó rövidebb lékai feliratokon nagyjából Amphiareo konstrukcióinak felel meg. Ez jól követhető például a nem párhuzamos, hanem enyhén befelé dőlő szárú „, $\mathrm{M}^{\prime \prime}$ vagy az ívesen görbülo alsó szárú „, $\mathrm{R}^{\prime}$ esetében. Az itáliai szerző a szerkesztéshez az 1:8 arányt javasolta, azonban ez az innsbrucki tumbán mind a képaláírásoknál, mind a sírfeliratnál 1:5 és 1:6 között mozog. A lékai síremlék nagyobbik tábláján összezsúfolt, változó szárvastagságú betüket találunk, ahol nem lehet az arányt meghatározni. A két rövidebb lékai feliratnál jóval kidolgozottabb konstrukciókról van szó. A vitruviusi arányokhoz képest azonban a nagybetüknél ismét eltérés mutatkozik (1:16), míg a kisbetüknél majdnem megközelíti azt (1:11). Tehát Bocskay feliratai közül az antikva ideális konstrukciójához leginkább a két lékai tábla kisméretü betúi igazodtak. A kalligráfus antikizáló kapitálisai, az aránybeli eltérések ellenére mégis rendkívül egységes benyomást keltettek, amely az egyes betük gondos megformálásából és a szövegek precíz elhelyezéséből adódott.

\section{A Nádasdy-Kanizsay-síremlék all'antica feliratai (1565)}

Bocskay György az innsbrucki táblák feliratozásával párhuzamosan egy másik síremlék antikva betüs feliratait is elkészítette. Nádasdy Tamás nádor és felesége, Kanizsay Orsolya lékai tumbájára ${ }^{186}$ szintén maratott és aranyozott, klasszikus kapitális szövegek kerültek. A megrendelés elnyerésében, valamint a betütípus és a technika kiválasztásában minden bizonnyal szerepe volt annak, hogy a kalligráfus az I. Miksa-síremlék feliratain ekkor már javában dolgozott. Ehhez szükséges mühelyét pedig valószínüleg a bécsi Nádasdy-házban rendezte be. ${ }^{187}$

Nádasdy Tamás 1562 júniusában váratlanul távozott az élők sorából. Igy a személyének méltó emléket állító síremlék elkészíttetése a feleségére maradt. Ekkor már a nádornak mind a mintakép kiválasztására, mind a mü felállításának a helyszínére megvoltak az előzetes elképzelései. Ezt valószínúsíti az a gyorsaság is, ahogyan - mindössze egy hónappal Nádasdy Tamás június 7-én ${ }^{188}$ lezajlott egervári temetése után - elkezdték Bécsben a síremlék ügyeit intézni. Szentgyörgyi Gábor, a néhai nádor titkára innen írt levelet Kanizsay Orsolyának, amelyben arról számolt be, hogy Udvardy Györgygyel, a Nádasdyak bécsi tiszttartójával közösen fogják ezt elrendezni ( „Az Zazloonak, es Koporso kw"nek gong'áth wÿssellők Udwardÿwal"). ${ }^{189}$

A lékai síremlék mintaképéül a bécsi főnemesség egyik jelentős alakjának, a város 1529-es török ostromakor elévülhetetlen érdemeket szerzett id. Niklas Graf zu Salmnak a tumbája szolgált, ${ }^{190}$ amelyet 1530-1546 között a bécsi Dorotheerkirchében állítottak fel. ${ }^{191}$ Nádasdy döntésében a gróf személyén kívül az az egyszerü tény is közrejátszhatott, hogy saját bécsi háza a templomtól mindössze néhány lépésnyire $^{192}$ állt. A Salm-tumba ábrázolási programja rendkívül közel áll a Lékán felállított síremlékhez. Mindkettő szabadon álló szarkofág, amelynek a fedelén azonos kompozíció található: az elhunyt(ak) térdel(nek) a feszület előtt. Hasonló a sírfelirat típusa és elhelyezése is, amely klasszikus antikva kapitálissal íródott, és táblája olvasópult-szerüen a fedlap alá került. Az oldallapok tekintetében azonban némi különbség mutatkozik, mivel a lékai tumbán itt nem az elhunyt tetteit megörökítő reliefek, hanem a fedlapról lekerült Nádasdy- és Kanizsay-címer, valamint Bocskay feliratos táblái találhatók.

A síremléket a Nádasdyak lékai várába szánták, ahol a nádor az 1550-es évek közepén egy új családi kriptát alakíttatott ki. A sírbolt valószínűleg a várkápolna előcsarnokának alsó szintjére került, a kápolna alatti, középkori csontház mellé. ${ }^{193}$ A tumbát 1566-ban a nádor temetése alkalmából állították fel itt. Az eseményről Sennyey Ferenc Kanizsay Orsolyához írt leveleiből értesülünk. Április 23-án arról számolt be, hogy „en ma ha isten agiarja Leukara megek ez heten ot leszek”. Hogy a temetés „mikor legen leszen ha kelletik kit isten tartoztasson ez heten mindent el re(n)delek ot Leukan", ahová „,beczbol az miet oda vitetek” és „ezÿde kezbe mint koporso mint zaslo ruhajat feketebe mek sze(r)zek", hogy ",tegek helere az en kegel(m)es mek holt uram testet ez heten". ${ }^{194}$ Két nappal később pedig így írt: „Amÿ az Zegen Vram themetese dolgat illetÿ, mÿkor isten kegelmessegeböl Sarwarra menek, arrol En Magam zolok Nag(sagod)dal, arra es isten segetsegeböl walamÿnt Jobban thwdom gondoth wÿselek". ${ }^{195}$ Sennyey későbbi, a nádornénak szóló leveleiben már nem kerül elő Nádasdy Tamás lékai temetése, így valószínüsíthetjük, hogy a terveknek megfelelően az április 23-a utáni héten erre valóban sor került. Ezt követően a vár Nádasdy-sírboltját folyamatosan használták, a legközelebbi temetés 1571ben Kanizsay Orsolyáé volt, aki végrendeletében 
meghagyta, hogy férjének a lékai várban felállított síremlékébe helyezzék végső nyugalomra. ${ }^{196}$ A kripta egykori berendezéséről egy 1670-es várösszeírás számol be, amely szerint a kápolnában, azaz a hozzá csatolt sírboltban egyaránt nyugodtak férfi és női családtagok, akiknek síremlékeihez (inkább koporsóihoz) a falakon epitáfiumok, valamint kisebb és nagyobb méretű halotti zászlók és valamiféle képek tartoztak. ${ }^{197}$ A 17. században a Nádasdy-Kanizsaysíremléket és a többi családtag földi maradványait innen a lékai ágostonrendieknél alapított új kriptába ${ }^{198}$ vitték át, amelyet Nádasdy III. Ferenc építtetett, részben a várbeli helyszín szűkössége miatt. ${ }^{199}$ A nádor és felesége tumbája jelenleg itt található.

Ami a síremlék feliratait illeti, ezeket Bocskay először 1565. szeptember 13-án említette Kanizsay Orsolyának: „Thowaba az mÿ az koporssora walo Irasth ÿlletÿ, kÿth paranchÿolt wolth, hogÿ en zerzenemmegh, az legh nagÿobÿkath el weghezthem thewbÿtÿs ÿrnam de nÿnch meegh az ÿras nalam, kÿrwl kellene ÿrnom, Jol leheth kewek kezemnel wannak, Mÿhelen meghozzak Gabrÿel wramtwl, azontwl hozza kezdek, es elwegghezem, egÿeb dolgoth hatra hagÿwan."200 Egy hónappal később, október 28-án egy másik, szintén neki szóló levelében utalt utoljára a munkára: „Az mÿ az koporso dolgath ÿllethÿ, egÿeb dolgaÿmoth hatra hagÿwan, megh aranÿazom allando keppen, Noha nem kÿchÿn munkath tezen, de bÿzon szÿwem zerÿnth fel weszem mÿnd mosth, mÿnd annak wthanna, az mÿkor N(agysagod) paranchÿolÿa."201

Tehát Bocskay közvetlenül Kanizsay Orsolyától kapta a megbízást a feliratozásra. A nagyobb táblával szeptemberben jóformán elkészült, a két kisebb tábla szövegét pedig még várta "Gabriel uramtól”, azaz Szentgyörgyi Gábortól, akinek a szerepével még foglalkozunk. A feliratokkal október végére készült el, amikor az aranyozás befejezéséről számolt be. Éppen e levélből derül ki az is, hogy Bocskay ekkor a bécsi Nádasdy-házban lakott, és a műhelyét is itt rendezhette be. Ezért elképzelhető, hogy a három lékai felirat kivitelezése egyfajta fizetség volt a szállásért cserébe. A kalligráfus minden bizonnyal előre méretre vágott táblákkal dolgozott. Ez azt jelenti, hogy 1565 őszére a tumba többi szobrászati része Bécsben már elkészült, vagy legalábbis az öszszeállítás a befejező fázisához érkezett.

A lékai síremléken tehát összesen három tábla található, amelyeket Bocskay aranyozott klasszikus antikva kapitális feliratokkal látott el. Bár a két levelében nem tett utalást arra, hogy ezek maratással készültek, mind a táblák anyaga (solnhofeni mészkö $^{202}$ ), mind a helyszíni vizsgálat azt támasztja alá, hogy a feliratokat az innsbruckiakhoz hasonlóan szintén evvel az eljárással kivitelezte.

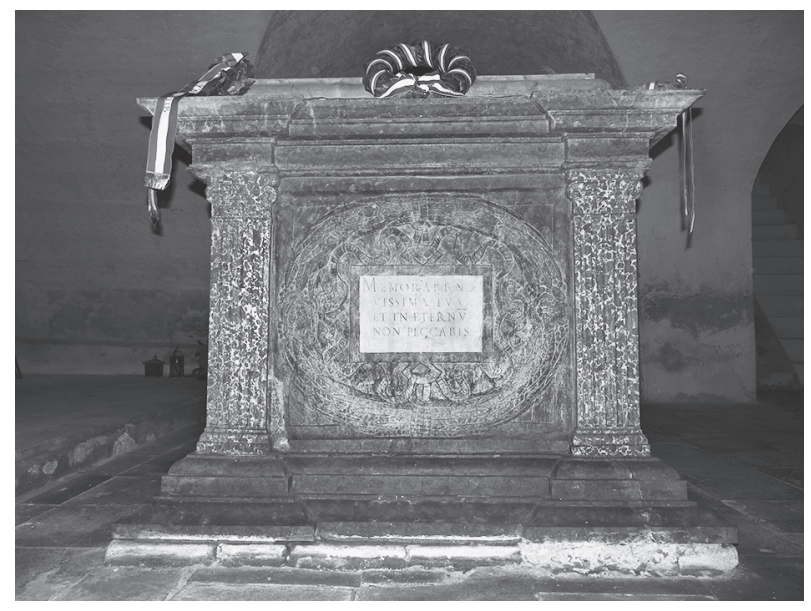

31. A síremlék keleti oldala (A szerzô felvétele, 2010)

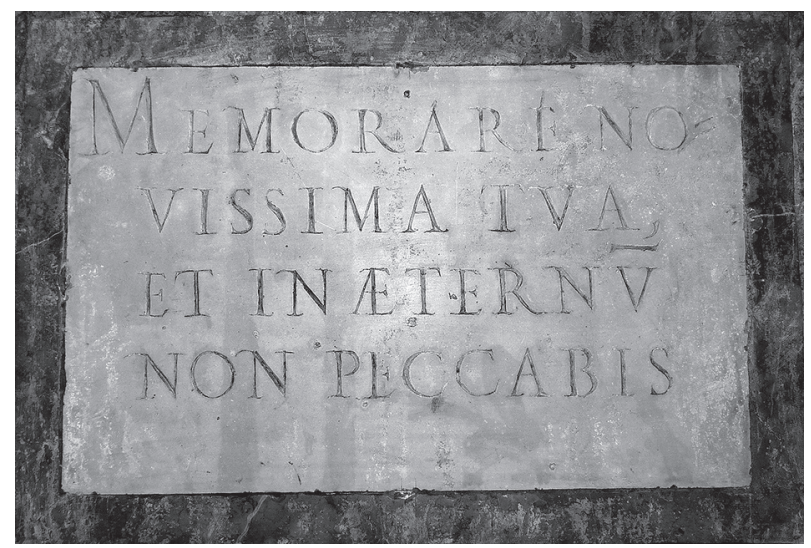

32. A feliratos tábla a keleti oldalon (A szerző felvétele, 2010)

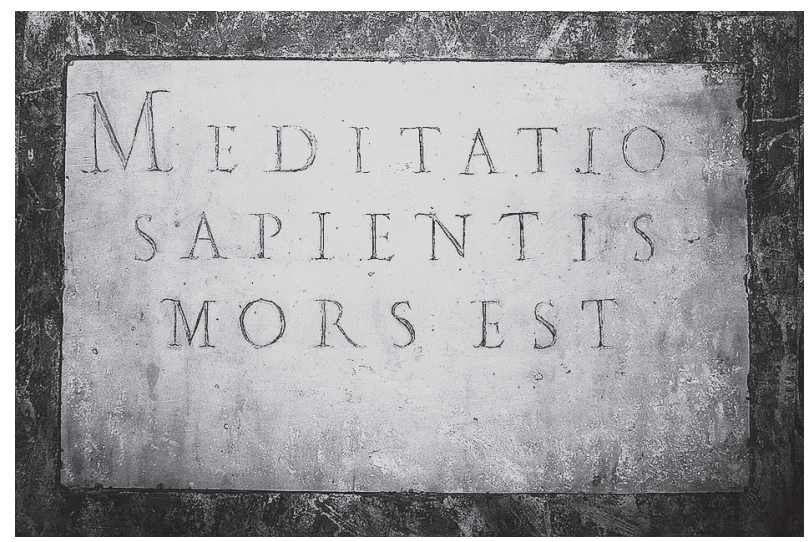

33. A feliratos tábla a nyugati oldalon (A szerzó felvétele, 2010)

A síremlék figurális díszítése a fedlapot leszámítva all'antica motívumokból építkezik. Anyagául vörös márványt (fedlap és oldallapok), valamint fehérrel pettyezett vörös Rotschecket (sarokpilaszterek) és fehér solnhofeni mészkövet (a két címer az oldallapokon és a három feliratos tábla) választottak. Négy sarkára kannelúrázott ión pilaszterek kerültek, párkányzata gazdagon profilozott. A két 


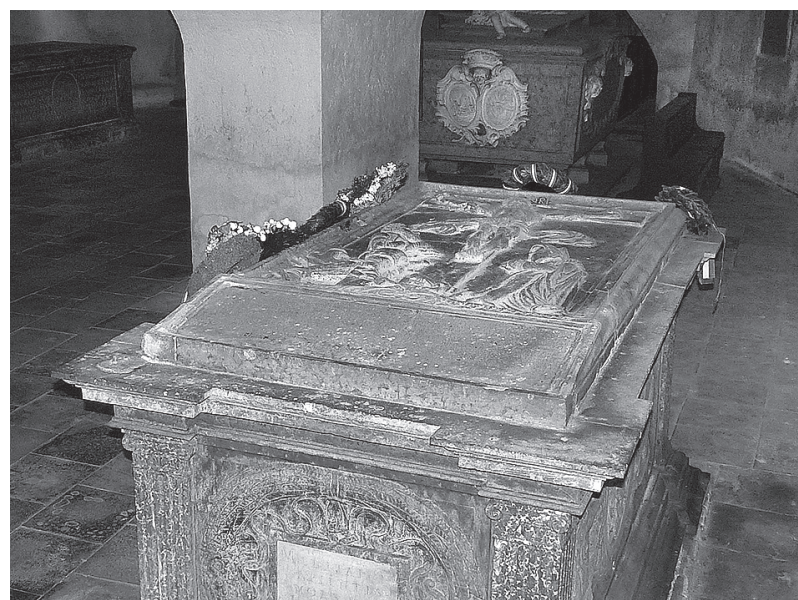

34. A sírfelirat megdöntött táblája (A szerző felvétele, 2010)

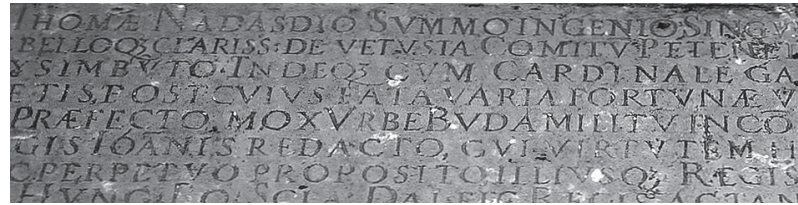

35. A sirfelirat részlete (A szerző felvétele, 2010)

hosszoldalon az ókori szarkofágok figuráit felidéző szárnyas, tunikás puttók tartják a babérkoszorúval övezett Nádasdy-, illetve Kanizsay-címert. A két rövidebb oldalra kerültek Bocskay all'antica feliratos tabulái $(22,5 \times 36 \mathrm{~cm})$, amelyeket szalagokkal rögzített babérkoszorúkba foglaltak (31. kép). A táblákon a halállal kapcsolatos, latin nyelvű szentenciák olvashatók: a keleti oldalon egy bibliai textus (32. kép), a nyugatin pedig egy antikizáló idézet (33. kép) (l. Függelék II/a).

A sírfelirat nagyméretü tábláját $(32,5 \times 104 \mathrm{~cm})$ egy akantusszal koronázott, profilozott vörösmárvány keretbe, a néző felé enyhén megdöntve helyezték el, amely a tumba fedlapjának a keretéhez alulról csatlakozik (34. kép). A hosszú, latin nyelvü szöveg Nádasdy Tamást méltatja, és a síremlék megrendelőjeként Kanizsay Orsolyát is megnevezi (l. Függelék II/b, 35. kép). Legutóbb Pálffy
Géza, valamint Bessenyei József hívta fel a figyelmet a sírfelirat jelentőségére. ${ }^{203}$ Szövegét elsőként Kovachich Márton György adta közre egy hoszszabb Nádasdy Tamás-életrajz függelékeként. ${ }^{204}$ A közlése alapjául szolgáló kéziratot ma az Országos Széchényi Könyvtár őrzi. ${ }^{205}$ A kötetet Istvánffy Miklós állította össze különböző kezektől származó történeti szövegekből. Közöttük szerepel az életrajz (190r-193v), amelyet a lékai sírfelirat követ (194r). A széljegyzetben a szerző, Szentgyörgyi Gábor is megnevezésre kerül. Ebből következik, hogy a Bocskay által a feliratok összeállítójaként említett "Gabriel uram" vele azonosítható. ${ }^{206}$

A kalligráfus mintáinak a vizsgálatakor említettük, hogy a három lékai felirat közül a sírfelirat (35. kép) a kevésbé sikerült darab. A sorok távolsága, a betűk szárvastagsága sem egyforma, sőt előfordul, hogy egy-egy kimaradt betút Bocskay utólag illesztett be a szövegbe. A betük mérete is változó: a kisbetük magassága $\mathrm{kb} .1 \mathrm{~cm}$, a nagybetúké pedig 1,3-1,9 cm. A kisebb táblák szövegei (32-33. kép) valamivel nagyobbak, 2-2,4 cm-es kisbetükből és 3,2-4,1 cm-es nagybetúkből állnak. A sírfeliratnál a hosszú szöveg teljes terjedelmü, jól olvasható közlése volt a cél, viszont a rendelkezésre álló tábla ehhez meglehetôsen kicsi volt, és ez egyenetlenebb munkát eredményezett. A két latin bölcsesség textusa finomabban megformált betűkből áll, amely megközelíti az innsbrucki síremlék feliratainak a színvonalát.

Kanizsay Orsolya tehát a férje és maga számára állíttatott lékai szarkofág antikizáló feliratait Bocskay Györggyel készíttette el, aki az innsbrucki síremlék azonos típusú betüit épp ekkor kivitelezte. A bécsi all'antica udvari ízléshez való igazodás azonban nem csupán ebben nyilvánult meg. Bár a síremlék mesterei a forrásokból egyelőre nem ismertek, az bizonyos, hogy a tumba többi szobrászati része szintén Bécsben készült. A reprezentatív, all'antica vörös-fehér márvány szarkofágot innen szállították 1566-ban a lékai vár új családi kriptájába, a nádor temetésére.

\section{FÜGGELÉK ${ }^{207}$}

I. Az innsbrucki I. Miksa-síremlék feliratai (15631568)

a) A 24 képaláírás:

(északi oldal, felső sor)

1. Miksa és Burgundiai Mária esküvöje Gentben (1477) Matrimonio cVm Maria Potentiss(I) ${ }^{\mathrm{mi}}$ Bvrgvndionv(m) / Dvcis Caroli filia contracto, opvlentissimæ $Æ$ Belga: / rvm aC Seqvanor(vm) Ditiones, Avstriacæ Domvi adiectæ.

\section{Az első guinegate-i csata (1479)}

Fvso ad Gvynegatam vicvm Gallorv(m), Qvi eX TRIGINTA / MILLIBVS HOMINVM CONSTABAT, EXERCITV, MAGNA PARS HA: / NNONIÆ, VNACVM IMPERIALI VRBE Cameraco, Recepta 
(nyugati oldal, felső sor)

3. Arras ostroma (1492)

Atrebatvm Arthesiæ Metropolis, Qve antea GALLOR(VM) ARMIS / CESSERAT, EGREGIO STRATAGEMATE PER NOCTVRNAS - INSIDIAS DE// / CEPTIS HOSTIVM CVSTODIIS, IN POTESTATEM REDACTA

4. Miksa római királlyá koronázása Aachenben (1486) Vivente adHVC patre Fride(Ri) ${ }^{\text {Co }}$ iII Imp(eratore) A SACRI Ro(MANI) IMPe(RII) ELEC// / TORIBVS, IN Regem Ro(manorvm) VNanimiter electvs, aC PAVLO POST / AQVISGRANI ADHIBITIS RITE CÆREMONIIS, CORONATVS

\section{A caglianói csata (1487)}

IVNCTIS CVM PATRVELE SigISMV(N)Do ARMis, ROVERETVM OP: / PIDVM EXPVGNATVM, AC VENETOR(VM) Copie, vnacvm Dvce / Roberto Sanseverino, aD vicvm Callianvm Delete.

6. Miksa bevonulása Hunyadi Mátyás halála után Bécsbe (1490)

VNIVERSA INFERIORIS AVSTRIÆ PROVINCIA, QVÆ VNACV(M) Metropo// / li Vienna, in potestatem Mathiæ CorviNI INCLYTI HVNGARIÆ RE// / GIS DEVENERAT, INTRA TRIVM MENSIVM SPACIVM, RECVPERATA

(déli oldal, felső sor)

7. Székesfehérvár ostroma (1490)

Alba regalis vrbs Nobilis(si) ${ }^{\text {ma }}$ in Qva Reges HVNGARIÆ, ET INAVGV// / RARI, ET SEPELIRI SOLEBANT, VALIDO EXERCITV CINCTA, ET EXPV: / GNATA, INGENSQ(VE) VNIVERSO ILLI REGNO, TERROR ILLATVS

8. Miksa lányának visszatérése Franciaországból (1493) Facta cvm Carolo viil Gallorv(m) Rege pace, Margaritha / FILIA VNACVM OPVLENTISSIMIS BVrgvnd(i $/$ ) aC Arthesiæ Co// / mitatibvs, ANTE ID TEMPVS A LVD(OVICO) : $\overline{\mathrm{XI}} \cdot$ OCCVPATIS, RECEPTA

(keleti oldal, felső sor)

9. A törökök visszaszorítása Horvátországban (1493)

Tvrcarv(M) INGENS MVLTitvdo QVE IN CROATIA ET SClavon(ia): / CVNCta Ferro Et igni vastaVerat, SOLIVS IPSIVS AVSPICIIS / AC ALIORVM OPE NE QVICQVAM IMPLORATA, INDE EIECTA

10. A Szent Liga megalapítása (1495)

Foedvs cvm Alex(andro) vi Pont(Ifice) Max(imo) Senatv Veneto ac Lvd(ovico) Sfortia in / itvm Qvo mediante Carolvs viII Gallor(vm), Rex, Regnvm Neapoli// / tanVm a Se sVbivgatvm, Deserere, aC DOMVM REDIRE COACTVS.

\section{Lodovico Sforza megkapja Milánót (1495)}

Dvcta in matrimoniv(m) Blanca Maria, Principis Mediolani fi// / lia, Recepto q(ve) a Lvdo(vico) Sfortia fidei ivramento, Dvcatvs Medi: / olani ad OBEDIENTIAM IMPERII SINE SANGVINE REDVCTVS

12. Szép Fülöp és Kasztíliai Johanna esküvője (1496)

Conciliatis inter filivm svvm Philipp(vm) aC inclytor(vm) Regvi Fer: / dinandi et Elizabethæ FILIAM IOANNAM NVPTIIS AD AMPLISS(IMORVM) His: / panie Regnor(vm) svcCessionem aditvs POSTERIS IPSIVS APERTVS.

(északi oldal, alsó sor)

13. A regensburgi csata (1504)

BOHEMI QVI SORORIVM IPSIVS AlberTVM BaVARIE DVCem, MERCE// / DE CONDVCTI, OPPVGNATVM ADVENERANT, MEMORABILI PRÆLIO / PROPE VRBEM RATISPONAM PLVRIMIS ILLOR(VM) INTERFECTIS, SVPERATI.

\section{Kufstein ostroma (1504)}

Kvefstainio ac Geroltzecko mvnitissimis arcibvs eXPVG / NATIS, SEPTEM INSignes PrefectVRÆ, Ditioni AvSTRIACÆ, PA: / RTIM ADIECTÆ, PARTIM QVASI POSTLIMINIO QVODA(M) RESTITVTE.

(nyugati oldal, alsó sor)

15. A gelderni herceg legyözése (1505)

Arnhemio QVod PRIMARIVM GeldriÆ oppidvm est, capto, Ca: / rolo Dvci Geldrie, gvi Gallor(vm) partes secvtvs, rebvs in infe: / riori Germ(ania) NOVANDIS SEMPER STVDVERAT, PAX SVPPLICI DATA

16. A Cambrai-i Liga (1508)

Percusso cym Ivlio $\cdot \overline{\mathrm{I}} \cdot$ Pont(ifice) Max(imo) ac Hispa(niÆ) et Gall(iæ) Regibvs foe: / dere, Veneti TOTA PROPEMOdV(M) CONTINENTI, QVAM IN ITALIA POSSI: / DEBANT, DEPVLSI, ET AD SVMMAM RERVM DESPERATIONE(M) ADACTI •

\section{Padova, Vicenza és Brescia bevétele (1509)}

Insignes Venetor(vm) vrbes, Patavivm, Vicentia, VNACVM Ma: / GNA FORI IVlii PARTE, IN POTESTATEM REDACTE, BRI: / XIA VERO AVXILIARIBVs Gallorvm ARMIS EXPVGNA ${ }^{\text {ta }}$

18. Massimiliano Sforza bevonulása Milánóba (1512) Societate cvm Ivlio Pont(ifice) et pagis Helvetiorv(m) contrac// $/^{\text {ta }}$ / Galli penitvs Italia eiecti, Maximil(ianvs)Q(ve) Sfortia, tot iam / annis EXVL, PATERNO INSVBRIÆ PRINCIPATVI RESTITVTVS. 
(déli oldal, alsó sor)

19. A második guinegate-i csata (1513)

IVNCTI CVM HENRICO 'VIII' ANGLOR(VM) REGE VIRIBVS, ITE: / RVM AD Vicvm GVynegata(M), LOCVM ANTIQVA CÆS(ARIS) VICTO/ $/^{\text {ria }} /$ FATALE(M), INSIGNI PRÆLIO PROFligatVs Gallor(VM) EXERCITVS

\section{Tournai ostroma (1513)}

Terrovana Morinor(vm) eXCisa, tornacvm vero PRISCA BELLI: / COSI A(C) FORTISSIMI NeRVIORVM POPVLI GLORIA, INSIGNIS CI: / VITAS, POST LEVEM OPPVGNATIONEM, IN FIDEM ACCEPTA ·

(keleti oldal, alsó sor)

21. A vicenzai csata (1513)

BARTHOLOMÆVs LivianVS, EXCELSI NOMINIS Dvx, CVM INGE(N): / TI VENETAR(VM) COPIARVM APPARATV, A' parva Casareanor(Vm) mili: / tVM Germa(nORVM) ac Hispa(norvm) manV, PRope' Vicentia(M) FVSVS Et FVGATVS

\section{A császári sereg kitörése Maranóból (1514)}

MaRANV(M) OPPIDV(M) ASTV CAPTV(M) OBSIDENTI ${ }^{\text {busq(ve) }}$ ID PAVLÓ POST VENETIS, ER: / VPTIONE inde facta, cvm Pavlo Manfrono, et Baltasar(e) SCI: / PIONE, ACERRIMIS HOSTIVM DVCIBVS, FOELICITER PVGNATVM ie

23. A Habsburg-Jagelló házassági szerződés (1515)

Conventy cym Hvngarie ac Poloniæ Regibvs Vien(N)Æ ha: / Bito CONTRACTISQ(VE) HiNC INDE MATRIMONIIS, NEPOTIBVS IPSIVS / VIA ACQVIRENDIS ampliss(Imis) Hvngariæ aC Bohe(miæ) Regnis, STRATA ie

\section{Verona ostroma (1516)}

Vrbs Verona opera ·M·(arciI) Antonil Colvmnæ, SVBMisSISQ(VE) PER GV: / LIELMV(M) ROGENDORFIV(M) COM(M)EATV, ET SVBSIDIIS ADVERSVS IMMENSAM Vim / oppVgnantivm Gallorvm et Venetorvm, STRENVE DEFENSA

\section{b) A sírfelirat:}

(a felirat a tumba északi oldalán kezdődik, és a keleti oldal végéig tart)

ImPERATORI Cæes(ARI) Maxim| iliano Pio; Foelici, Avg(vsto) PR/INCIPI, TVM PACI $/ \mathrm{s}$, TVM BELLI ARTiBVS, OMNIV(M) I ÆTATIS SVÆ RegVM / LONGE CLARISSIMO, SVB CVIVS FOELICI IM|PERIO, INCLYTA GERMANIA| DVLCISSIMA IPSIVS PATRIA, TAM ARMIS QVAMI LITERARVM STVDIIS PLVS QVAM VNQVAM A I NTEHAC FLORERE, CAPVTQ(VE) SVPER ALIAS NATIO(N) ES | EXTOLLERE CEPIT, CVIVS / INSIGNia I FACTA
TABELLIS INFERIO|RIBVS, QVAM VIS SVB COMPENDIO| EXPRESSA CONSPICIVNTVR IMP(ERATOR)I CAS(AR) Ferdinandvs / pivs, Foelix, Avgvstvs, I Avo

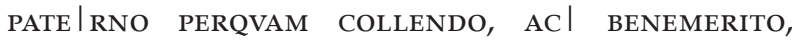
PIETATIS, ATQVe GRATITVDinis| ERgô - P(Osvit) · NatVs EST $\cdot \overline{\text { XXVII }} \cdot$ MartiI $\cdot$ AnNo D I OMINI $\cdot M$. $\overline{\mathrm{CCCC}} \cdot \overline{\mathrm{LVIIII}} \cdot$ OBitT An(N)ol Do(MINI) $\cdot \mathrm{M} \cdot \overline{\mathrm{DXIX}}$ Die $\cdot \overline{\mathrm{XII}} \cdot$ Mensis IANVARII

II. A lékai Nádasdy-Kanizsay-síremlék feliratai (1565)

a) Az oldallapok feliratai:

keleti oldal $^{208}$

Memorare no// / vissima tVa / et in æternv(m) / NON PECCABIS

nyugati oldal ${ }^{209}$

MeditATIO / SAPIENTIS / MORS EST

b) A sírfelirat:

Illvstr(I) D(OMI)No Thome Nadasdio Svmmo ingenio SingVlari ViRTVTe VIRO COMPLVRIVM LiNGVAR(VM) / PERItissi(M)O PACE BELloq(VE) Clariss(imo) de vetvsta Comitv(m) Petenedior(vm) FAMILIE PROGNATO IN ITALIA OPTIMARV(M) / ARTIVM StVdys IMBVto - INDEQ(VE) CVM Cardinale gaietano Bvda(m) Reverso Regi Hvn(gariæ) Lvdo / vico a SECRETIS, POSTCVIVSFATA VARIAFORTVNÆVICISSITVDI(N)E ACto primv(M) AVSPicis MElio / RIBVS BVDEN(SI) Prafecto mox VRbe Bvda militv(M) inco(N)Sta(N)tia Tvrcis dedita, Solliman(N)I pote(N)tia / in ARbitriv(M) Regis IOAN(N)IS REDACTO, CVI VIRTVTEM HOM(IN)IS ADMIRANTIA THESAVRIS, SED DE(N)VO / PROPRIO SVO AC PERPETVO PROPOSITO, ILLIVSQ(VE) REGIS PERMissv PATRIÆ RESTITVTO SACRATIS(SIMI) AC / potentis(simi) Rom(ani) Hvng(ariae) Bo(hemiae) Scla(voniae) Dal(matiae) etc. Regis ac tandem IMP(ERATORIS) FERDINANDI CONSILIARIO PERPE// / TVVM Svm(M)ISQ(VE) AC CO(N)TINVATIS APVD HVNC AD EXTREMV(M) VITÆ DVM PERFVNCTO HONORIBVS, AC PRIMVM / TAVERNICOR(VM) REGIORVM MAG(IST)RO, MOX Dal(matiae) Croa(tiae) et Scla(voniae) Bano, Deinde ivdici Cvrize Regił / Statim svp(re)mo generaliq(ve) Capitaneo Postremo Palatino regni ET PRO REgI, OPTIMO FIDELIS / SIMO CONSILIO ARMISQ(VE) TVRCARVM PROFLIGATORI PATRIÆ ILLVSTRATORI Conivnx amantissima / Vrsvla Canisæa merens P(IISSIME) P(OSVIT).

Obitt Anno Domini $\cdot M \cdot D \cdot L \cdot X \cdot I I \cdot$ Qvarto no// NAS IVNIAS AN(N)O ÆTATIS SVÆ $\cdot$ LXIIII : 


\section{JEGYZETEK}

1 Valószínűleg 1545-ben került Oláh Miklós magánírnokaként a kancelláriára (Bocskay György levele Nádasdy Tamáshoz, Bécs, 1557. jún. 9., MNL OL E 185). A hivatal működéséhez legutóbb 1. Fazekas 2012, 49-51.

A tanulmány az ELTE BTK Müvészettörténet-tudományi Doktori Iskolájában megvédett doktori disszertációm alapján készült (vö. Gulyás Borbála: „Egy „magyar Zeuxis" Bécsben. Bocskay György [1510 k.-1575] kalligráfus tevékenysége" című doktori értekezésének vitája. Művészettörténeti Értesítő LXII. 2013, 337-351). Hálásan köszönöm témavezetőmnek, Galavics Gézának és opponenseimnek, Farbaky Péternek és Mikó Árpádnak, valamint András Editnek, Franz Caramelle-nek, Dorothea és Peter Diemernek, Fazekas Istvánnak, Petr Fidlernek, Havasi Krisztinának, Renate HolzschuhHofernek, Manfred Kollernek, Lővei Pálnak, Zuzana Ludikovának, Lukas Madersbachernak, Marosi Ernőnek, Pálffy Gézának, Friedrich Polleroßnak, Ingeborg Schemper-Sparholznak, Johannes Stephan Schlöglnek és Szentesi Editnek a tanulmány elkészítéséhez nyújtott segítségét. Köszönöm továbbá a lipcsei GWZO-nak, az MTA Isabel és Alfred Bader müvészettörténeti kutatási támogatásának, az MTA Egyezményes tanulmányút- és Peregrináció-programjának, az Osztrák-Magyar Akció Alapítvány ÖAD Ernst Mach- és KurzaufenthaltStipendiumának, a PALATIUM Research Programme of the ESF Short Visit Grant-jének, valamint az OTKA K 105005 sz. pályázatának és az MTA BTK TTI „Lendület” Szent Korona Kutatócsoportnak (2012-2017), hogy kutatásaimat támogatták.

2 Gulyás 2013a; Gulyás 2013b.

3 Például a római Porta del Popolo diadalívének klaszszikus kapitális, vésett feliratát 1563 körül IV. Pius pápa Giovanbattista Palatinóval, a korszak egyik jelentős írásmintakönyv-szerzőjével készíttette el (Wardrop 1952, 25).

$4 \mathrm{~A}$ bécsújhelyi Zeughaus antikizáló főkapuját (1524, Francisco da Pozzo és más észak-itáliai mesterek) antikva betűs felirat díszítette, amely Ferdinándot a "CES(AR) AVG(VSTUS)" (I. Miksa) unokájaként és az „IMP(ERATOR)” (V. Károly) fivéreként említette (Kaiser Ferdinand I. Kat., No. III.11. [Norbert Koppensteiner]; Polleroß 2006, 212). Ekkoriban készült az a nagyméretü, propagandisztikus jellegü portrébüszt is, amely az ifjú Ferdinándot all'antica páncélban, mellén a császári sassal ábrázolta (Kaiser Ferdinand I. Kat., No. IV.20. [Eliška Fučíková]; Holzschuh-Hofer 2010a, 261-264).

5 Holzschuh-Hofer 2008, 652-653; Holzschuh-Hofer 2010a, 270-271.

6 Thomas 1993, 109; Holzschuh-Hofer 2007, 313-314.

$7 \mathrm{Az}$ építéstörténethez legutóbb 1. Thomas 1993; Polleroß 1998, 96-98; Geschichte der bildenden Kunst in Österreich 3., No. 51. (Eckart Vancsa); Holzschuh-Hofer 2007. Pozzóhoz és Ferraboscóhoz 1. Koppány 1984; Farbaky 2003.

8 Kühnel 1956, 258; Polleroß 1998, 97.

9 Holzschuh-Hofer 2008, 649-653; Holzschuh-Hofer 2010b, 67-83. Hasonló ablakkeretek díszítették a prágai Belvedere és a pozsonyi vár új épületét is (Holzschuh-Hofer 2008, 759761. kép; Holzschuh-Hofer 2010b, 14. kép). Utóbbi átépítésében Pietro Ferrabosco is részt vett (Farbaky 2003, 129).

10 Polleroß 2006, 215; Holzschuh-Hofer 2008, 653; Holzschuh-Hofer 2010a, 271-272. Ezért olvasható az 1552- es évszám annak az új kútnak a káváján is, amelyet a kapu mellett, az udvarban alakítottak ki.

11 Serlio 1542 (Polleroß 2006, 215). A müvet Jakob Rechlinger fordította németre, és Serlio neve csak a kolofonban jelent meg (Fontaine Verwey 1976, 183-186; Bury 1989, 100; Jonge 2004, 278-279). A mú I. Ferdinánd tulajdonában lévő díszpéldányát (ÖNB SHAD, Alt Einb 72.O.57, Polleroß 2006, 5. kép) antik érmékkel és klasszikus antikva kapitális possessor-felirattal díszített, vaknyomásos kötés borítja, metszetei lavírozottak. Második kiadását Coecke van Aelst özvegye adta ki 1558-ban Antwerpenben (Fontaine Verwey 1976, 191-192; Bury 1989, 100).

12 Polleroß 2006, 217-218.

13 Holzschuh-Hofer 2008, 652; Holzschuh-Hofer 2010a, 272.

14 Serlio 1537, VI. fejezet, XXIv-XXIIr (Polleroß 2006, 215.)

15 Farbaky 2003, 129; Holzschuh-Hofer 2008, 645. 15. j.

16 Valthin Kraus 1553 februárjában és márciusában a külső oldalra 71, a belső oldalra pedig 6 aranyozott fémbetüt készített, és ezek darabszáma alapján kapott fizetést. Az 1949-es restauráláskor a szöveget még 3 betűvel megtoldották (Holzschuh-Hofer 2008, 645).

17 A feliratos tabulák alapszínére a forrásokban nem történik utalás, és a restaurátori vizsgálat sem hozott evvel kapcsolatban eredményt. Renate Holzschuh-Hofer szürke vagy vörös színüként rekonstruálta a feliratos mezőket (Holzschuh-Hofer 2008, 658, 775. kép), ma már azonban inkább a vörös hátteret tartja valószínünek (a szerző szíves közlése).

18 Lővei 2001; Lővei 2004; Mikó 2005a, 213-217.

19 Ezt a sötétszürke homokkövet (Dornbacher Flyschquarzsandstein) használták a Hofburg homlokzatának új nyíláskereteihez is. A kapu vörös-sötétszürke átfestésére először 1763-1828 között került sor, majd eredeti megjelenését a 19. század közepén visszaállították, végül 1927ben, illetve 1975-ben ismét ilyenre festették (Beseler 2008, 668-669).

20 Ezt 1544-45-ben alakították ki Miksa főherceg lovagi tornái számára, és 1552-54-ben bővítették ki (Holzschuh-Hofer 2007, 320-321, 388. kép).

21 DaCosta Kaufmann 1978, 24-26; Vocelka 1978, 143144; Pfaffenbichler 1992, 24-28; Winkler 1980; Kiss 2004, 90-92; Gulyás 2012, 254-256.

22 Wir sind Helden Kat., Nr. 3.12., 3.14. (Matthias Pfaffenbichler)

23 Pfaffenbichler 1992, 24; Polleroß 2006, 216; Gulyás 2014. 24 Müller 1982.

25 Silver 1990; Bodnár 2005; Dürer és kortársai Kat., No. II-IV. I. Miksa életében egyedül a Diadalkapu látott napvilágot (1519). A müvek későbbi megjelentetésében I. Ferdinánd aktív szerepet vállalt, támogatta a Diadalmenet első teljes kiadását (1526) és a Diadalkapu második kiadását (1526-1528) is (Chmelarz 1886, 311-312; Schauerte 2001, 423-425, 455-458; Werke für die Ewigkeit Kat., Nr. 1. [Veronika Sandbichler]; Bodnár 2005, 28, 75).

26 Mitchell 1979; Strong 1984, 75-97; Watanabe O'Kelly 1999, 723; Polleroß 2006, 208-209; Philipp 2011.

27 V. Károly bolognai császárrá koronázása után az augsburgi birodalmi gyülésre ment. Két ekkor tartott bevonulásán (1530. máj. 11., 13., Innsbruck, Schwaz) I. Ferdinánd is jelen volt (Blaha 1950, 12, 132).

28 Feil 1853; Vocelka 1978, 135-138; Almási 2005a, 28-29. 
29 DaCosta Kaufmann 1978, 22-24; Dmitrieva-Einhorn 2002, 363-365, 381, 385-386; Bůžek 2008; Büžek 2009, 168-188.

30 Amikor Frankfurtban ünnepélyesen kihirdették I. Ferdinánd császári címét (1558. márc. 14.), jelenlegi ismereteink szerint nem készült efemer diadalív (Rudolph 2011, 152-155).

31 Rotis 1558, FIVr-GIr; Feil 1853, 4-5.

32 Mattioli 1559, DIIv-DIVr; Cornova 1802, 75-80.

33 Wünsch 1914, 18-34; Blaha 1950, 42-48, 102-104, 132-133, 169-172; DaCosta Kaufmann 1978, 27; Vocelka 1978, 144-146; Kayser 1979, 280-289; Louthan 1997, 3542; Dmitrieva-Einhorn 2002, 363, 365, 369-374, 381, 385; Rasmussen 2014.

34 Lazius 1563 (ÖNB SHAD, Alt Prunk *38.E.51; Alt Mag 61530-B).

35 Stainhofer 1566.

36 Kiss 2004, 92-94; Pálffy 2005, 258-261, 263; Pálffy 2010, 333-336, 339-344; Gulyás 2012, 256-258; Coronatus Posonii Kat., 52-55; Pálffy 2014; Soltész-Tóth 2014, 42-45.

37 Galavics 1986, 61; Galavics 1987, 229-230; Jankovich Miklós gyüjteményei Kat., No. 280 (Mikó Árpád); Farbaky 2003, 130; Gulyás 2012, 257; Mikó 2013.

38 Ludiková 2009; Gyulai 2012.

39 „le porte (...) erano con somma magnificenza quasi di marmor fabbricate" (Conti 1589, 381v, idézi: Farbaky $2003,130)$.

40 Lietzmann 1987, 113-114; Polleroß 2006, 216; Geschichte der bildenden Kunst in Österreich 3., No. 51 (Eckart Vancsa).

41 Czeike 1959-1960.

42 Czeike 1959-1960, 75-78; Busch 1973, 19-21.

43 Lazius 1560 (ÖNB SHAD, Alt Prunk 19.Bb.28., vö. Busch 1973, 20-21; Polleroß 2006, 216-217.)

44 Kratochwill 1965; Trenkler 1978.

45 Egyik gyüjtemény sem maradt fenn, mindössze néhány darab későbbi őrzési helyét ismerjük. A Schallauzerlapidárium hat publikált köve utóbb Hieronymus Beck von Leopoldsdorf gyüjteményében, a Bécs közeli Ebreichsdorf kastélyában tünt fel (közülük Aurelia Ursula sírkövét a kápolna külső falába illesztették, 5. kép). Ez a harmadik, szintén az udvar környezetében létrehozott ókori kőtár későbbi, az 1570-es években keletkezett, darabjairól több kéziratos leírás készült (Carolus Clusius, 1580 k., Batholomäus Jupp, 1588, vö. Busch 1973, 21-25; Trenkler 1978, 192). Lazius gyüjteménye a 19. század közepén semmisült meg, amikor a neki otthont adó házat lebontották. Ekkor egy Brigetióból származó oltárkövet még leírtak itt (Sacken 1853, 89; Trenkler 1978, 191).

46 Sacken 1853, 89; Trenkler 1978, 191; Busch 1973, 16 19; Louthan 1997, 31-33.

47 Stenhouse 2005, 118-124.

48 Lazius 1546; Lazius 1551.

49 Perger-Brauneis 1977, 19-20. szerint bár a hagyomány konkrét forrásokkal nem igazolható, a templom 8 . századi alapítása mégis elképzelhető.

50 Wiener Stadt- und Landesarchiv, Bécs, Oberkammeramtsrechnungen, B1/1., Bd. 87. (1554), 168v, 172v, Bd. 88. (1555), 111rv (vö. Camesina 1872, 4; Perger-Brauneis 1977, 22-23; Kohn 1998, 11.)

51 A feliratok a Bécs egyháztörténetét és templomait feldolgozó, 17. századi Codex Testarellóban maradtak fenn (ÖNB SHAD, Cod. 8227, 9-20, vö. Kohn 1998, 48-52), ennek alapján közli őket Camesina 1872, 4., 4. j. A templomban ma is látható Lazius fali epitáfiuma, amelyet itteni temet- kezése alkalmából, a halála után két évtizeddel állítottak (1586), később pedig az új templomtérben is megőriztek. 52 Velence, 1549. nov. 16. (Voltelini 1890, No. 6415); Lhotsky 1941-1945, 142-143; Polleroß 2006, 218-219.

53 A szobor eredetije még a 16. században Spanyolországba került, ma csupán az egykorú másolata ismert (KHM Antikensammlung, Inv.-Nr. VI 1), amelyet az 1980-as évekig az eredetinek tartottak (Kugler 2003, 210; Kaiser Ferdinand I. Kat., No. X.5-6. [Kurt Gschwandtler]). 54 Polleroß 1998, 98-99.

55 Polleroß 2006, 219.

56 Róma, 1561. jan. 4. (Voltelini 1890, No. 6510), 1. Lhotsky 1941-1945, 158.

57 Bécs, 1560. aug. 20. (Voltelini 1898, No. 16080.) Strada ugyanekkor tárgyalt a neves velencei Loredangyüjteményről is, amelynek antik szobrairól tudjuk, hogy végül nem a császár, hanem $\mathrm{V}$. Albert bajor választófejedelem vásárolta meg, szintén Strada közvetítésével, a saját gyüjteménye számára. Strada a müncheni antikvitások és a könyvtár számára épített Antiquarium tervezésében is közremüködött (Busch 1973, 202; Lietzmann 1987, 114; D. Diemer-P. Diemer 1995; Seelig 2008, 44).

58 ÖNB SHAD, Cod. 13009 (Boeheim 1888, No. 4793), 1. Holzmair 1961, 79-81.

59 Lhotsky 1941-1945, 112; Kugler 2003, 212; Polleroß 2006, 219.

60 I. Ferdinánd végrendelete, Bécs, 1554. feb. 25. (Voltelini 1890, No. 6465), 1. Lhotsky 1941-1945, 154-155; Scheicher 1979, 67.

61 ÖNB SHAD, Cod. 10308. A 45 leveles, vízszintes formátumú, szépen letisztázott papír kézirat uralkodói díszpéldány lehetett, mivel vaknyomásos kötésén és az előzéklapokon akvarellel a császár címerei ismétlődnek (Holzmair 1961, 82-85; Kaiser Ferdinand I. Kat., No. X.1. [Günther Dembski]).

62 Bibliotheca Apostolica Vaticana, Róma, Reg. Lat. 661. (Lhotsky 1941-1945, 140-142; Holzmair 1961, 81-82; Polleroß 2006, 219.)

63 Bécs, 1556. aug. 20. (Boeheim 1888, No. 4936., 1. még uo., No. $4907,4948,4956$.)

64 Kaiser Ferdinand I. Kat., No. VIII.13. (Georg KuglerHeinz Winter); Polleroß 2006, 219. A Szent Korona legkorábbi hiteles ábrázolását - Lazius munkatársaként - szintén Lautensack rajzolhatta le ugyanebben az időben (1. erről Buzási Enikő és Pálffy Géza tanulmányát a MÉ jelen számában).

65 Lazius 1558 (ÖNB SHAD, Alt Prunk 57.C.11).

66 Jansen 1982; Jansen 1992; Louthan 1997, 24-46.

67 Busch 1973, 199-201; Louthan 1997, 28-29.

68 ÖNB SHAD Cod. 9411., folytatása: Uo., Cod. 8412. 1552-ben Zsámboky János szintén egy római numizmatikával foglalkozó mű javított kiadásával próbálta először felhívni magára Miksa főherceg figyelmét (Almási 2005b, 895; Almási 2009, 147-148).

69 Panvinio 1557a; Panvinio 1557b. Az itáliai szakértőt I. Ferdinánd szerette volna szolgálatába is fogadni, de erre végül nem került sor (Almási 2005a, 31-32.).

70 1547-48-ban a Forum Romanumon antikva betüs feliratos márványtáblák kerültek elő, amelyek két névlistát tartalmaztak (római királyok és konzulok Kr. u. 13-ig, illetve a hadi sikerek alkalmából triumphust tartó személyek Romulustól Kr. e. 19-ig). A lelet feltárását Alessandro Farnese bíboros támogatta, aki saját palotájában helyezte 
el a táblákat, majd nyilvánosan a Palazzo dei Conservatori belső udvarán állíttatta ki őket, innen kerültek 1586-ban a palotán belül a mai helyükre (Sala della Lupa) (Beard 2003).

71 Panvinio 1558 (Stenhouse 2005, 1-3, 104-111, 116-117). 72 Stenhouse 2012.

73 II. Miksa alatt a város melletti nyaralókastély, a Neugebäude kialakításában is részt vett, saját bécsi házát pedig 1566-tól „itáliai stílusban” építtette át, és nyilvános antikvitásgyüjteményt hozott benne létre (Lhotsky 19411945, 160-163; Lietzmann 1987, 113-114; Polleroß 2006, 220; Szücs 2012, 1. még 66-67., 88-89. j.).

74 Ehhez felhasználtuk: Schönherr 1890a; Egg 1974; Scheicher 1986; Scheicher 1999; Werke für die Ewigkeit Kat.; Seidl 2003; D. Diemer-Haidacher 2004; Baresel-Brand 2007, 30-34.

75 Egy forrás szerint például Flinkenstein várában 1510 körül egy ládában a Diadalkocsi egy példánya mellett 24, a sírhoz tartozó képet („XXiiii Bild auf das Grab”) is öriztek (vö. Schauerte 2001, 36-40). Az egyik jelenethez 1. Szentesi 2010, 388-392.

76 Ezek sorában eredetileg szerepelt, azonban végül nem került kivitelezésre Szent István és Gizella nagyméretű szobra, valamint elkészült, de később rossz minősége okán beolvasztották V. László figuráját. Szent István kisméretü szobra a szentek sorozatában ma is megtalálható (Scheicher 1999, 89-90; Endródi 2000; Történelem kép Kat., II-16., II-17. [Endrődi Gábor]).

77 Esztergom, 1527. nov. 30. ÖStA HHStA HA Familienakten, Kart. 17., Konv. 2., 10-11. (vö. Schönherr 1884, No. 1730.)

78 ÖStA HHStA HA Familienakten, Kart. 17., Konv. 2., 29., 30., 31. Ebből kettő közölve: Werke für die Ewigkeit Kat., No. 63.1-63.2 (Katharina Seidl).

79 Innsbruck, 1547. márc. 9. (Voltelini 1890, No. 63876390.)

\section{Fidler 1987.}

81 ÖStA HHStA HA Familienakten, Kart. 17., Konv. 2., 107-108. A datálatlan iratra valaki utólag, ceruzával az „1555. VI. 28." dátumot írta rá. Mivel Schallauzer még római királyként szólítja meg benne I. Ferdinándot, mindenképpen 1556 augusztusa előtt kellett készülnie. Közli: Schönherr 1890a, 264-265.

82 KHM Schloß Ambras, Inv.-Nr. KK 4971.

83 Werke für die Ewigkeit Kat., No. 53 (Katharina Seidl). 84 Vogel 1933; Laubach 2010. Köszönöm Pálffy Gézának, hogy az utóbbi müre felhívta a figyelmemet.

85 A kilenc vázlatrajzból talán egy azonosítható az ugyanebben az iratcsomóban található, évszám nélküli alaprajzzal, amely a tumba körül a tervezett 40 Habsburgős elhelyezését mutatja: ÖStA HHStA HA Familienakten, Kart. 17., Konv. 2., 73 .

86 Ilg 1889; Scheicher 1983.

87 Albertina, Bécs, Inv.-Nr. Arch 9685.

88 ÖStA HHStA HA Familienakten, Kart. 17., Konv. 2., 109-110. Közli: Schönherr 1890a, 265-266. Az irat „aug. 27-én" kelt, Schönherr pontosabb datálása a következőkön alapul: Strada 1558 októbere után érkezett meg Bécsbe (terminus post quem), a tanácsadók a szövegben nem neveznek meg egyetlen konkrét mestert sem, viszont tudjuk, hogy 1561 áprilisában már szerződést kötöttek az Abel fivérekkel a tumba kivitelezésére (terminus ante quem). Ugyanez a tanácsadó testület (Schallauzer, Ferrabosco, Strada) készített javaslatot a Hofburg északnyugati részén fekvő, azóta lebontott Kaiserspital építésé- hez is, amelynek belső udvara a Stallburgéhoz volt hasonló (Lietzmann 1987, 113; Holzschuh-Hofer 2007, 320-321).

89 D. Diemer 2004, 43.

90 Innsbruck, 1561. dec. 10. Während die nöthigen Marmorstücken in Carrara gebrochen worden wären, sei Meister Arnold auf Befehl und auf Kosten des Kaisers nach Rom und anderen italienischen Städten geritten, um „alda etlichen künstliche arbaiten und antiquitäten” zu besichtigen. (Schönherr 1890b, No. 7535, ugyanerről 1. Innsbruck, 1561. dec. 13. Uo., No. 7541), 1. Dressler 1973, 148, 266. j.; D. Diemer 2004, 46.

91 Julius Caesar a részben fiktív Habsburg-genealógiában kapott volna helyet. Még szerepelt Kölderer (1527) és Schnurff javaslatában (1547), 1. 78-79. j. 1560-ban azonban az innsbrucki vezetés a tervbe vett további szobrok, köztük Caesar esetében is kifogásokat emelt: nem tartoznak szorosan a Habsburg-rokonsághoz, túl drága lenne az öntésük (Innsbruck, 1560. aug. 26., Schönherr 1890b, No. 7395).

92 Ferdinánd főherceg 1596-os hagyatéki leltára 22 antik fémbüsztöt (, 22 gossne mettallene antiquitetsprustpilder") említ Ambrasban, a kert mellett található mühelyeknél (ÖNB SHAD Cod. 8228, 121r, Boeheim 1888, No. 5556, CCXLV.). A szobrok az 1730-as ambrasi inventárium szerint ugyanott, de már az antikvitások közt találhatók (Werke für die Ewigkeit Kat., No. 62 [Katharina Seidl]). Ezekből ma 20-at itt (KHM Schloß Ambras), egyet pedig a Bayerisches Nationalmuseumban (München) öriznek. Ferdinánd főherceg antikvitásgyüjteményéhez 1. Ambraser Kunstkammer Kat., 157-185. (Alfred Auer); All'Antica Kat.

93 A Diadalkapu alapján több, csak a 24 jelenetet és képaláírást tartalmazó kivonat is megjelent (németül $1520 \mathrm{k}$. két kiadás, 1559-ben egy, latinul 1520 k. egy) (Schauerte 2001, 258-284, 462-465).

94 L. 81. j.

95 Haidacher 2004, 82-87.

96 Egyetlen kivétel a 3. jelenet, Arras ostroma (1492), amelynek a sorozatban később kellene következnie. Elképzelhető, hogy Seld az 1482-es előnytelen arrasi békekötés ellenpontjaként tudatosan illesztette ide (Haidacher 2004, 84).

97 Bécsben a Kölderer 1527-es terveit tartalmazó, kronologikusan rendezett iratcsomóban megtalálható a Diadalkapu 24 német verses szövege, az alkancellár néhány történeti jegyzete, valamint több összesített, datálatlan lista, amely a tumbára került végleges szövegeket tartalmazza: ÖStA HHStA HA Familienakten, Kart. 17., Konv. 2., 37-67.

98 ÖStA HHStA HA Familienakten, Kart. 17., Konv. 2., 50-63. Közli (a lelőhely megadása nélkül): Primisser 1812, 86-94; Schönherr 1890a, 266-268.

99 I. Ferdinánd utasítása a rajzok Prágából Bécsbe továbbításáról: Bécs, 1564. jún. 2. (Schönherr 1890b, No. 7817). Seldnek a véleményezési folyamatban való részvételére utal az is, hogy halála után a Bécsbe küldött rajzok egy része a hagyatékából került elő: Prága, 1565. jún. 2., Innsbruck, 1565. aug. 18. (Schönherr 1893, No. 9777, 9810). A vázlatok közül ma mindössze az 1 . számú relief tervrajza ismert (Brüsszel, Bibliothèque Royale, Dressler 1973, 47., 85. kép).

100 ÖStA HHStA HA Familienakten, Kart. 17., Konv. 2., 48-49. Közli (a lelőhely megadása nélkül): Schönherr 1890a, 268. 
101 Klosterarchiv, Schwaz, Cod. 94a. Köszönöm Lukas Madersbachernak, hogy az iratokra felhívta a figyelmemet.

102 Uo., Cod. 94.1690 körül Justin Kaltprunner innsbrucki ferences szerzetes szerette volna megírni a síremlék történetét, a lista a munkához Bécsből beszerzett iratok közé tartozhatott (Ruggenthaler 2006, 87-94). Az innsbrucki levéltárban ezen kívül megtalálható mindkét schwazi irat másolata is, azonos tartalommal: TLA KS I. K 1453, Pos. III., 247-249, 268-338.

103 Bécs, 1561. máj. 3. (Schönherr 1890b, No. 7461.)

104 L. 90. j.

105 Innsbruck, 1562. jún. 16. (Schönherr 1890b, No. 7593.) Érdekes adalék, hogy a két Abel fivér emiatt azt javasolta, próbálják meg bevonni a firenzei Medici-udvarban múködő Giambolognát is a reliefek készítésébe (Innsbruck, 1562. jún. 4., Schönherr 1890b, No. 7592). Erre azután valószínüleg azért nem került sor, mert a flamand mester bérét a fivéreknek kellett volna állnia (D. Diemer 2004, 48).

106 H. n., 1562. okt. 5. ÖStA AVA FHKA HKA HP Bd. R 254., 253r (Vö. Birkreg, No. 16. Köszönöm Fazekas Istvánnak, hogy ezekre a regesztákra felhívta a figyelmemet.) Ugyanerről 1. még h. n., 1562. nov. 14. Uo., 287r (vö. Birkreg, No. 18).

107 ÖNB SHAD, Cod. ser. n. 2664.

108 ,FERDINANDO Pontentissimo, ac Christianissimo Principe, eius nominis primo, Romanor(um) Imperatore Augustissimo, ac Germaniæ, Hungariæ, Bohemiæ, Dal(matiæ) Croatiæ, et Sclauoniæ etc. Rege, foeliciter regnante, Georgius Bochkaÿ, a Raziniÿa pannonius, ex Magnatum vetustissimo nobilissimo atq(ue) clar(issi)mo Hungaricæ et Sclauonicæ gentis stemate oriondus Maiestatis suæ veteranus Seruitor et Aulæ familiaris, in perpetuum artificy sui testimoniu(m), diuersas Characterum formas, in hoc libro contentas, rara ac singulari quadam ingenÿ dexteritate, ex gratiosa Eiusdem Ma(iesta)tis uoluntate, non partendo aduersæ etiam suæ Continuæ valetudiny effigiauit (...) M.D.L.X.II."

109 „Mer gar ain langgeletes puech in rot Leder eingebunden, auf baiden saiten mit vergult getruckhten Mödlen, in der mite der Kaiserisch Adler und vergult, mit grien daffeten Päntlen, dar Inn auf Pargement allerlaj schöne schrifften" ÖNB SHAD, Cod. 8228., 395v-396r (vö. Boeheim 1888, No. 5556., CCXCII.)

110 L. 141. j.

$111 \mathrm{Az}$ alábbiakban a lelőhely után zárójelben jelezzük, ha a forrásról regeszta is készült.

112 L. 106. j.

113 Innsbruck, 1563. ápr. 23. (Schönherr 1890b, No. 7670.) A levél címzettje valószínúleg Nicolò Madruzzo trentói várnaggyal azonosítható, ezért vonatkozhatnak a megadott méretek az innen beszerzendő fekete márványra (D. Diemer 2004, 46).

114 I. Ferdinánd innsbrucki tartózkodásának célja a tridenti zsinat eredményeinek az áttekintése volt. Bocskay kollégája, Forgách Ferenc alkancellár, a későbbi humanista történetíró Antwerpenből valószínüleg szintén májusban érkezett Innsbruckba, júniusban pedig már bizonyosan itt tartózkodott (Károlyi 1881; Almási 2006, 1408-1409).

115 Bécs, 1563. máj. 5. (MNL OL E 21, X. köt., 33., MTABRreg, No. 107., közli: Kapossy 1956, No. 107). Hogy Bocskay ebből az 50 Ft-ból Innsbruckba utazott, az ugyanennek az iratnak a bécsi megfelelőjéből derül ki: Bécs, 1563. máj. 5. ÖStA AVA FHKA HKA GB Bd. 83. 351v (vö. Birkreg, No. 21.)

116 Innsbruck, 1563. okt. ÖStA AVA FHKA HKA HP

Bd. E 256., 343v (vö. Birkreg, No. 23.)

117 Innsbruck, 1564. júl. 27. TLA KS I. K 1453, Pos. I. (vö. Birkreg, No. 26; Schönherr 1893, No. 7850.)

118 Innsbruck, 1564. aug. 21. TLA OÖK KB Bd. 294 (GuH 1564), 404r-404v (vö. Birkreg, No. 268; Schönherr 1890b, No. 7860.)

119 Bár a forrásokban csak 24 darabról esik szó, valójában több táblával kell számolnunk. A 24 képaláíráson kívül az eredetileg 18 darabból álló sírfelirat tábláit is Bocskayval készíttették el.

120 A megfelelő mélység elérése érdekében a maratást általában többször ismételték, majd a felületet olykor faragással, csiszolással is tovább alakították, végül színezték, vagy ahogyan itt is történt, aranyozták (Trautmann 1869, 1-5; Wastler 1887, I.).

121 A jóval gyakoribb magas maratás („Hochätzung”) épp ellenkezőleg készült, itt a háttér mélyedt be a kőlapba.

122 L. a lékai kripta síremlékeinek 2006-ban végzett restaurátori felmérését (Nimmrichter 2006).

123 A tumba legutóbbi restaurálásában (2000-2004) közremüködő Manfred Koller és Johannes Stephan Schlögl szíves közlése szerint a lapok anyaga fekete márvány, amely a Garda-tó mellől származik. Ez egybevág a forrásokban említett Trento környéki lelöhellyel (vö. 106. j.). A restauráláshoz 1. Pischl-Schlögl 2002; AntretterPichler 2004; Schlögl 2004; http://www.steinrestaurierung. at/praesen.htm, letöltés ideje: 2014. júl. 21.).

124 Bocskay György levele Kanizsay Orsolyához (Bécs, 1565. okt. 28., MNL OL E 185).

125 L. 118. j.

126 Manfred Koller és Johannes Stephan Schlögl szíves közlése. A restaurálás során a lepergett aranyozást festékkel retusálták (Antretter-Pichler 2004, 217-218; Schlögl 2004, 200).

127 Valószínűleg Nürnbergből terjedt el a 15. század utolsó negyedében, eleinte fémtárgyak, jellemzően páncélok díszítményeinél használták. Kövön a 15. század vége táján tünt fel először. Kieslinger szerint egy 1490 körül készült, Madonnát ábrázoló márványamulett a legkorábbi ismert emlék (Kieslinger 1963).

128 Wastler 1887, I.; Wallner 1912, 4-8; Kieslinger 1965a, 185; Kieslinger 1965b, 84.

129 Kieslinger 1965b, 85-87, 91-93, 101.

130 A „Verordnetenratsstube” és a „Bürgerstandsstube" két, ekkor épült márványportáljára maratott, antikva betüs feliratok kerültek. Kieslinger 1959; Kieslinger 1963, 36. szerint a kőlapok anyaga márvány, Krug 2006, 165-168. szerint mészkő.

131 Artliche künste 1531, CIv-CIIv (ÖNB SHAD, Alt Prunk *44.S.179), másik kiadása: Erfurt 1531. (Doede 1958, 91. 8. j.); Helmreich 1567 (Zajic 2004, 232. 452. j.)

132 Kieslinger 1965b, 91-92, 101.

133 L. 116. j.

134 L. 124. j.

135 ÖStA AVA FHKA HKA HQuB Nr. 1. (1563), 58v (idézi: Dominkovits-Pálffy 2010, 776. 36. j.); Toma 2010, 861. 136 Bécs, 1567. márc. 19. (Birkreg, No. 48.)

137 Bécs, 1567. ápr. 3. TLA KS I., K 1453, Pos. IV., 398399. (vö. Schönherr 1893, No. 10032.) 
138 L. 141. j.

139 Sterzing, 1564. okt. 9. TLA OÖK KB Bd. 294. (GuH 1564), 464r-464v (vö. Birkreg, No. 30; Schönherr 1890b, No. 7879.)

140 Innsbruck, 1565. ápr. 12. TLA OÖK KB Bd. 300. (GuH 1565), 245v-246v (vö. Schönherr 1893, No. 9747); ÖStA HKA NÖ Kammer, Rote Nr. 44. Konv. 1565. Mai, sine fol. (Birkreg, No. 33; Kreyczi 1887, No. 4381.)

141 Bécs, 1565. máj. 9. TLA OÖK KB Bd. 299. (GeH 1565), 198rv (vö. Birkreg, No. 34; Schönherr 1893, No. 9762). Az innsbrucki vezetés újabb sürgetése ugyanekkor: Innsbruck, 1565. máj. ÖStA AVA FHKA HKA HP Bd. E 262., 143r (vö. Birkreg, No. 34a).

142 Innsbruck, 1565. aug. 3. TLA OÖK KB Bd. 300. (GuH 1565), 503v-505r (vö. Schönherr 1893, No. 9810.)

143 Innsbruck, 1565. dec. 7. TLA OÖK KB Bd. 299. (GeH 1565), 470r; eredetije: TLA KS I. K 1453, Pos. IV., 388. (vö. Schönherr 1893, No. 9861.)

144 Innsbruck, 1566. márc. 21. TLA KS I. K 1453, Pos.

IV., 389-396. (vö. Schönherr 1893, No. 9923.)

145 Innsbruck, 1567. márc. 3. TLA OÖK KB Bd. 312.

(GuH 1567), 104v-105v (vö. Birkreg, No. 46; Schönherr 1893, No. 10026.)

146 D. Diemer 2004, 54-55.

147 Bécs, 1567. márc. 19. (1. 136. j.)

148 Uo.

149 Prága, 1567. márc. 22. ÖStA HHStA SA UA AA

Fasc. 94., Konv. A., 56. (vö. Voltelini 1898, No. 16100.)

150 Bécs, 1567. ápr. 3. (1. 137. j.)

151 Prága, 1567. ápr. 13. TLA OÖK KB Bd. 311. (GeH

1567), 144r (vö. Birkreg, No. 49; Schönherr 1893, No. 10035.$)$

152 Innsbruck, 1567. máj. 23. TLA OÖK KB Bd. 312.

(GuH 1567), 272r-272v (vö. Birkreg, No. 50; Schönherr 1893, No. 10039); eredetije: ÖStA AVA FHKA HKA RA

Fasc. 202/A., 79r-81r (vö. Birkreg, No. 51.)

153 Innsbruck, 1567. máj. 23. TLA OÖK KB Bd. 315. (GM 1567/I.), 563r-563v.

154 Innsbruck, 1568. dec. 23. TLA OÖK KB Bd. 322.

(GM 1568/II.), 2090r-2090v.

155 Innsbruck, 1568. márc. 20. TLA OÖK KB Bd. 321.

(GM 1568/I.), 414r-414v.

156 Innsbruck, 1568. ápr. 28. TLA OÖK KB Bd. 321. (GM 1568/I.), 581r.

157 H. n., 1568. máj. 5. ÖStA AVA FHKA HKA HP Bd. E 277., 225v; eredetije: ÖStA AVA FHKA HKA RA Fasc. 202/A., 85r-85v (vö. Birkreg, No. 62-63.)

158 H. n., 1568. máj. 7. ÖStA AVA FHKA HKA HP Bd. R 280., 188r; eredetije: ÖStA AVA FHKA HKA RA Fasc. 202/A., 86r-87v (vö. Birkreg, No. 63.)

159 H. n., 1568. máj. 7. ÖStA AVA FHKA HKA HP Bd. R 280., 186v (vö. Birkreg, No. 64).

160 Innsbruck, 1568. máj. 11. TLA OÖK KB Bd. 318. (GuH 1568), 447v-448v; eredetije: TLA KS I. K 1453, Pos. IV., 407-408. (vö. Birkreg, No. 65; Schönherr 1893, 10120).

161 Bécs, 1568. máj. 22. TLA KS I. K 1453, Pos. IV., 409412. (vö. Birkreg, No. 66; Schönherr 1893, No. 10121).

162 Innsbruck, 1568. jún. 2. TLA OÖK KB Bd. 318. (GuH 1568), 533r-534r; eredetije: TLA KS I. K 1453, Pos. IV., 413-414. (vö. Birkreg, No. 67; Schönherr 1893, No. 10122., utóbbi tévesen Bocskay által Innsbruckba már elküldött táblákat említ, pedig ennek még csak a szándéka szerepel a forrás eredetijében.)
163 H. n., 1568. jún. 8. TLA KS I. K 1453, Pos. IV., 415416. (vö. Birkreg, No. 69; Schönherr 1893, 10123.)

164 Innsbruck, 1568. jún. 8. TLA OÖK RB Bd. 109., 24 r. 165 Innsbruck, 1568. júl. 28. TLA OÖK KB Bd. 322. (GM 1568/II.), 1107v-1108v.

166 Speyer, 1570. okt. 24. ÖStA AVA FHKA HKA GB Bd. 109., 719v és Bd. 111., 328r (A számadáskönyvi bejegyzés: ÖStA AVA FHKA HKA HZAB Bd. 26., 576r-576v, Pálffy Géza szíves közlése.) (Vö. Schlager 1850, 711-712; Birkreg, No. 90; Kreyczi 1887, No. 4452; Boeheim 1888, No. 5209.)

$167 \mathrm{Az}$ udvari titkári fizetését 1554-től a Magyar Kamara utalta, amely 1562-től évi 400 Ft (Gulden) volt (valószínüleg már a tanácsosi javadalmazásával együtt) (Status erogationum Camerae Hungaricae 1573., ÖStA AVA FHKA HKA HFU Rote Nr. 52., Konv. 1587. Dez., 168r, Fazekas István, illetve Pálffy Géza szíves közlése, 1. még Fazekas 2008, 212., 6. j.). Közvetlenül az udvartól 1563-tól további évi 100 Ft-ot (Gulden) is kapott (pl. 1565. nov. 5. $100 \mathrm{Ft}$ „,Georg Bochkhaij Römischer Kayserlicher Majestät etc. hungerischer secretari und diener" számára, ÖStA AVA FHKA HKA HZAB Bd. 20., 147v, Pálffy Géza szíves közlése, vö. Boeheim 1888, No. 5000), amelyet feltehetőleg kalligráfusi tevékenységéért folyósítottak.

$168 \mathrm{Az}$ egész síremlék (bronzszobrok, tumba, kovácsoltvas rács) összes költsége kb. 22000 Guldent tett ki, ehhez jött még a Hofkirche építésére elköltött kb. 43000 Gulden (Widmoser 1972, 202-203).

169 Innsbruck, 1563. okt. 13. (Schönherr 1890b, No. 7717.$)$ 170 Innsbruck, 1568. júl. 22. TLA OÖK KB Bd. 322. (GM 1568/II.), 1260v-1261r.

171 Innsbruck, 1568. aug. 6. TLA OÖK KB Bd. 322. (GM 1568/II.), 1370r-1370v; Innsbruck, 1568. aug. 13. TLA OÖK KB Bd. 322. (GM 1568/II.), 1418r-1418v

172 1568. okt. 31. TLA OÖK RB Bd. 109., 284v

173 L. 154. j.

174 L. 146. j.

175 L. 90. j.

176 Származási hely: Laas (Dél-Tirol, Vintschgau)

(Manfred Koller szíves közlése).

177 L. 105., 139-140. j. és Dressler 1973, 55.

178 Antretter-Pichler 2004, 217.

179 L. 106., 123. j.

180 Antretter-Pichler 2004, 217.

181 Morison 1972, 266-275; Kloos 1992, 153-154.

182 Anderson 1972, IX-XI.

183 Sperling 1989, 223-228; Mikó 2005a, 231.

184 Ritoókné 1994, 318.

185 Meiss 1976

186 Mikó 2005b, 628.

187 L. 134., 136. j.

188 ,7 die Junii sepultus est in Egheruar" (Armbruster Mihály bejegyzése Albani Csirke György Bibliájába, ELTE Egyetemi Könyvtár, M 342, Pálffy Géza szíves közlése).

189 Szentgyörgyi Gábor levele Kanizsay Orsolyához (Bécs, 1562. júl. 20., MNL OL E 185)

190 Ludiková 2006, 184. Köszönöm a szerzőnek, hogy e tanulmányára felhívta a figyelmemet.

191 A Salm-kriptához 1. Deutschmann 1975, 167; Perger-Brauneis 1977, 172; Csuk 1999, 22-23. (Köszönöm Ingeborg Schemper-Sparholznak, hogy az utóbbit a rendelkezésemre bocsátotta.) A Salm-tumba 1879 óta a Votivkirchében található. 
192 L. 135. j. A két épület közelségét mutatja, hogy egy alkalommal a kolostorbeli Ágoston-rendiek arra hivatkozva próbálták megakadályozni a ház munkálatainak a folytatását, hogy az új épület árnyékot fog vetni rájuk (Sárkány Antal levele Nádasdy Tamáshoz, Bécs, 1556. júl. 17., Komáromy 1911, 89).

193 A vár átépítése 1550-től 1557-ig zajlott (MNL OL E 185, MTANreg; FKNreg; Tóth 1966-1970; Koppány 1987, 224; vö. ÖKT LVI., Fig. 34-36). A várkápolna előcsarnoka 1554-1557-ben készülhetett el, mivel a „torony” kifejezés a forrásokban kizárólag ekkor fordul elő.

194 Sennyey Ferenc levele Kanizsay Orsolyához (Sempte, 1566. ápr. 23., MNL OL E 185).

195 Sennyey Ferenc levele Kanizsay Orsolyához (Léka, 1566. ápr. 25., MNL OL E 185).

196 Eberhardt, 1570. dec. 31. (MNL OL NRA, Fasc. 584., No. 17). Az özvegy nádorné 1571. március 6-án hunyt el, temetésére március 12-én került sor Lékán (Nádasdy II. Ferenc levele Batthyány Boldizsárhoz, Keresztúr, 1571. márc. 6., MNL OL P 1314, No. 31933, vö. Dominkovits-Pálffy 2010, 777).

197 „Capella, sine Altari, in qua Praedecessores D(omi) ni Comitis Familiae Nadasdianae Fratresq(ue) et Sorores ejusdem sunt Sepulti cum Epitaphÿs et Vexillis majorum, minor(um) vero Imaginibus." Az irat két, lényegében azonos példányban maradt fenn: MNL OL UC, Fasc. 68., No. 43., 1.; ÖStA AVA FHKA HKA HFU Rote Nr. 231., 1670. Okt., 263. A forráscsoporthoz 1. Viskolcz 2010, 877-878.

198 Toma 2010, 866-867. Erről részletesebben 1. a MÉ e számában Ugry Bálint tanulmányát.

199 „mivel eleim temető helye szorossága, és egyébiránti való alkalmatlansági miatt Leukai váramban rendetlen, holott Isteni szolgálat sem tartatthatik naponként, rendeltem ugyan azon Leukai városomban uj szentegyházat, és temető helyt csináltatnom, szándékozván hogy abban eleim meg hidegedet tetemeit által vitethessem" - Nádasdy III. Ferenc meghívója az alapkőletételre Batthyány I. Ádámhoz (Seibersdorf, 1656. jún. 12., MNL OL P 1314, No. 32461).
200 Bocskay György levele Kanizsay Orsolyához (Bécs, 1565. szept. 13., MNL OL E 185).

201 Bocskay György levele Kanizsay Orsolyához (Bécs, 1565. okt. 28., Uo.) (vö. 124. j.).

202 L. 122. j.

203 Pálffy 1999, 29; Bessenyei 2005, 3.

204 Kovachich 1798, 128-137, a sírfeliratot közölte még Podhradczky 1834, 54; Horváth 1838, 119; Zimmerl 1953, No. 110; Stöger 1989, 52-56.

205 Kézirattár, Fol. Lat. 2775.

206 Bocskay és a titkár ekkor már régóta ismerte egymást a Magyar Királyi Kancelláriáról, ahol Szentgyörgyi 1548-tól egy rövid ideig írnokként dolgozott (Fazekas 2008, 216-217).

207 A feliratokat a síremlékek alapján, betühíven közöljük. A kis- és nagybetük különbségét érzékeltetjük, a klasszikus antikva kapitális szövegekbe beszúrt, kisebb méretü kapitális vagy kurzív kiegészítéseket külön jelöljük. A rövidítések jelzéseit (vessző, kettőspont, szöveg fölötti vízszintes, illetve hullámos abbreviatúra) feloldottuk, és a kiegészítések kerek zárójelbe kerültek. A többi írásjelet, a számok fölötti vízszintes vonást, illetve az elválasztójeleket (kettőspont, illetve //) meghagytuk. A sortörést / jelöli. Az innsbrucki sírfeliratnál (I/b) a táblák határát I jelzi. A sorzáró arabeszkeket egységesen jelöli. A 24 képaláírásnál (I/a) a szövegek alatt található sorszámokat elhagytuk, mivel ezek nem Bocskaytól származnak.

208 Vö. „In omnibus operibus tuis memorare novissima tua, et in aeternum non peccabis (Bármit teszel, gondolj halálodra, akkor sohasem fogsz bünt elkövetni)." Sir 7,36 .

209 Vö. „omnem sapienti vitam meditationem esse mortis” Hieronymus, Epist. 60, 14, 2, valamint „nullius rei meditatio tam necessaria est quam mortis", Seneca, Epist., 70, 18 (Zimmerl 1953, 54).

210 A jegyzék az eredeti forrásokat tartalmazza, a regeszta alapján idézett egyéb források a lábjegyzetekben találhatók.

\section{RÖVIDÍTÉSJEGYZÉK}

AH - Ars Hungarica

AHA - Acta Historiae Artium

Birkreg - Ernst Birk Bocskay Györgyre vonatkozó regesztái (ÖStA HHStA, Sonderbestände, Nachlaß Ernst Birk, Nr. 147.)

FKNreg - Forster Gyula Nemzeti Örökséggazdálkodási és Szolgáltatási Központ, Budapest, Tervtár, Jankovich Miklós regesztái (MNL OL E 185 alapján)

JKSAK - Jahrbuch der Kunsthistorischen Sammlungen des Allerhöchsten Kaiserhauses

KHM - Kunsthistorisches Museum, Bécs

MÉ - Művészettörténeti Értesítő

MNL OL - Magyar Nemzeti Levéltár Országos Levéltára, Budapest

MNL OL NRA - MNL OL Magyar Kamara archívuma, Neo-regestrata acta (E 148)

MNL OL UC - MNL OL Magyar Kamara archívuma, Urbaria et conscriptiones (E 156)
MTA BTK MI LR - Magyar Tudományos Akadémia, Bölcsészettudományi Kutatóközpont, Müvészettörténeti Intézet, Levéltári Regesztagyüjtemény

MTABRreg - MTA BTK MI LR, A-I-14 (Kapossy János regesztái, MNL OL E 21, Magyar Kamara archívuma, Benignae resolutiones alapján)

MTANreg - MTA BTK MI LR, A-I-51/a (Jankovich Miklós regesztái, MNL OL E 185 alapján)

ÖKT - Österreichische Kunsttopographie

ÖNB SHAD - Österreichische Nationalbibliothek, Sammlung von Handschriften und alten Drucken, Bécs

ÖStA - Österreichisches Staatsarchiv, Bécs

ÖStA AVA FHKA HKA - ÖStA, Allgemeines Verwaltungsarchiv, Finanz- und Hofkammerarchiv, Hofkammerarchiv

ÖStA AVA FHKA HKA GB - ÖStA AVA FHKA HKA Alte Hofkammer, Hoffinanz, Gedenkbücher

ÖStA AVA FHKA HKA HFU - ÖStA AVA FHKA HKA Alte Hofkammer, Hoffinanz, Hoffinanz Ungarn 
ÖStA AVA FHKA HKA HP - ÖStA AVA FHKA HKA Alte Hofkammer, Hoffinanz, Hoffinanzprotokolle

ÖStA AVA FHKA HKA HQuB - ÖStA AVA FHKA HKA Alte Hofkammer, Hoffinanz, Hofquartiersbücher

ÖStA AVA FHKA HKA HZAB - ÖStA AVA FHKA HKA Alte Hofkammer, Hoffinanz, Hofzahlamtsbücher

ÖStA AVA FHKA HKA RA - ÖStA AVA FHKA HKA Sonderbestände, Sammlungen und Selekte, Reichsakten

ÖStA HHStA - ÖStA, Haus-, Hof- und Staatsachiv

ÖStA HHStA HA - ÖStA HHStA, Hausarchiv

ÖStA HHStA SA UA AA - ÖStA HHStA, Staatenabteilungen, Ungarische Akten, Allgemeine Akten
ÖZKD - Österreichische Zeitschrift für Kunst- und Denkmalpflege

TLA - Tiroles Landesarchiv, Innsbruck

TLA KS - TLA, Kunstsachen

TLA OÖK - TLA, Oberösterreichische Kammer

TLA OÖK KB (GeH) - TLA OÖK Kopialbücher (Geschäft von Hof

TLA OÖK KB (GM) - TLA OÖK Kopialbücher (Gemeine Missiven)

TLA OÖK KB (GuH) - TLA OÖK Kopialbücher (Gutachten an Hof)

TLA OÖK RB - TLA OÖK, Raitbücher

\section{FORRÁSJEGYZÉK ${ }^{210}$}

\section{MNL OL, Budapest}

E 148 Fasc. 584., No. 17. (Kanizsay Orsolya végrendelete, 1570. dec. 31.)

E 156 Fasc. 68., No. 43. (Léka tartozékai, 1670. szept. 26.)

E 185 Bocskay György levele Nádasdy Tamáshoz (Bécs, 1557. jún. 9.), Bocskay György levelei Kanizsay Orsolyához (Bécs, 1565. szept. 13., 1565. okt. 28.), Sárkány Antal levele Nádasdy Tamáshoz (Bécs, 1556. júl. 17.) (Komáromy 1911, 89.), Sennyey Ferenc levelei Kanizsay Orsolyához (Sempte, 1566. ápr. 23., Léka, 1566. ápr. 25.)

Szentgyörgyi Gábor levele Kanizsay Orsolyához (Bécs, 1562. júl. 20.)

P 1314 No. 31933 (Nádasdy II. Ferenc levele Batthyány Boldizsárhoz, Keresztúr, 1571. márc. 6.), No. 32461. (Nádasdy III. Ferenc meghívója Batthyány I. Ádámhoz, Seibersdorf, 1656. jún. 12.)

ÖStA, Bécs

AVA FHKA HKA

Alte Hofkammer, Hoffinanz

GB Bd. 83., 351., Bd. 109., 719., Bd. 111., 328.

HFU Rote Nr. 52., 168., Rote Nr. 231. (Léka tartozékai, 1670)

HP Expedit (E) Bd. 256., 338., 343., Bd. 262., 143., Bd. 277., 225., Registratur (R) Bd. 254., 253., Bd. 280., 186., 188.

HQuB Nr. 1. (1563), 58.
HZAB Bd. 20., 147., Bd. 26., 576.

RA Fasc. 202/A., 79-81., 85-87.

HHStA

HA Familienakten Kart. 17., Konv. 2., 10-11., 29-31., 3767., 107-110.

Sonderbestände Nachlaß Ernst Birk, No. 147. (Bocskay Györgyre vonatkozó cédulák)

SA UA AA Fasc. 94., Konv. A., 56.

TLA, Innsbruck

KS I. K 1453 Pos. I., Pos. III., 247-249., 268-338., Pos. IV., 388-396., 398-399., 407-416.

OÖK KB Bd. 294. (GuH 1564), 404., 464., Bd. 299. (GeH 1565), 198., 470., Bd. 300. (GuH 1565), 245-246., 503505., Bd. 311. (GeH 1567), 144., Bd. 312. (GuH 1567), 104-105., 272., Bd. 315. (GM 1567/I.), 563., Bd. 318. (GuH 1568) 447-448., 533-534., Bd. 321. (GM 1568/I.) 414., 581., Bd. 322. (GM 1568/II.) 1107-1108., 12601261., 1370., 1418., 2090.

OÖK RB Bd. 109. (1568/II.) 24., 284.

Klosterarchiv, Schwaz

Cod. 94., 94a

\section{IRODALOM}

All'Antica Kat. - Sabine Haag Hrsg.: All' Antica. Götter und Helden auf Schloss Ambras. KHM Schloss Ambras - Innsbruck, 23. Juni bis 25. September 2011. Wien 2011.

Almási 2005a - Almási Gábor: A respublica litteraria és a császári udvar a 16. század második felében. Aetas 20. 2005, 5-37.

Almási 2005b - Almási Gábor: Két magyarországi humanista a császári udvar szolgálatában. Dudith András (1533-1589) és Zsámboky János (1531-1584). Századok 139. 2005, 889-922., 1131-1167.

Almási 2006 - Almási Gábor: Variációk az értelmiségi útkeresés témájára a 16. században. Forgách Ferenc és társai. Századok 140. 2006, 1405-1440.

Almási 2009 - Almási, Gábor: The Uses of Humanism. Johannes Sambucus (1531-1584), Andreas Dudith
(1533-1589), and the Republic of Letters in East Central Europe. (Brill's Studies in Intellectual History, 185) Leiden-Boston 2009.

Ambraser Kunstkammer Kat. - Elisabeth Scheicher Ortwin Gamber - Kurt Wegerer - Alfred Auer: Die Kunstkammer. (Führer durch das Kunsthistorische Museum, 24) Innsbruck 1977.

Anderson 1972 - David M. Anderson: Introduction. Cresci and His Renaissance Alphabet. In: Uő Intr.: A Renaissance Alphabet. Il Perfetto Scrittore, Parte Seconda. Giovan Francesco Cresci. Madison-London 1972, V-XXII.

Antretter-Pichler 2004 - Sigrid Antretter - Birgit Pichler: Die Restaurierung und Konservierung des Renaissancegitters am Maximiliansgrabmal (2000-2004). In: D. Diemer-Haidacher 2004, 212-219. 
Artliche künste 1531 - Artliche künste mancherlei weise Dinnten vnd aller hand Farben zubereyten. Auch Goldt vnd Silber sampt allen Metallen auß der Fedder zu schreyben. Mit vil andern nützlichen Künstlin Schreyb feddern vn(d) Pergamen allerley farben zu ferben. Auch wie man schrifft vn(d) gemelde vff Stäheline Eysenne waffen vnd deßgleichen Etzen sol. Allen Schreybern Brieff malern sampt andern solcher Künsten liebhabern ganz lustig vnd fruchtbarlich zu wissen. Mainz 1531.

Baresel-Brand 2007 - Andrea Baresel-Brand: Grabdenkmäler nordeuropäischer Fürstenhäuser im Zeitalter der Renaissance (1550-1650). (Bau+Kunst. Schleswig-Holsteinische Schriften zur Kunstgeschichte, 9) Kiel 2007.

Beard 2003 - Mary Beard: Picturing the Roman triumph. Putting the Fasti Capitolini in context. Apollo 158. July 2003, 23-28.

Beseler 2008 - Susanne Beseler: Das Schweizertor und die Metamorphosen seiner Oberfläche. ÖZKD 62. 2008, 660-670.

Bessenyei 2005 - Bessenyei József: A Nádasdyak. Budapest 2005.

Blaha 1950 - Herta Blaha: Österreichische Triumph- und Ehrenpforten der Renaissance und des Barock. Wien 1950.

Bodnár 2005 - Bodnár Szilvia: I. Miksa császár megdicsőülése: Diadalmenet, Diadalkocsi és Diadalkapu. In: Dürer és kortársai Kat., 23-75.

Boeheim 1888 - Wendelin Boeheim Hrsg.: Urkunden und Regesten aus der K. K. Hofbibliothek (1). JKSAK VII. 1888, XCI-CCCXIII.

Bury 1989 - John Bury: Serlio. Some Bibliographical Notes. In: Christof Thoenes ed.: Sebastiano Serlio. Sesto Seminario Internazionale di Storia dell'Architettura. Milano 1989, 92-101.

Busch 1973 - Renate von Busch: Studien zu deutschen Antikensammlungen des 16. Jahrhunderts. Tübingen 1973.

Bůžek 2008 - Václav Bůžek: Der festliche Einzug Ferdinands I. in Prag am 8. November 1558. In: Friedrich Edelmayer - Martina Fuchs - Georg Heilingsetzer - Peter Rauscher Hrsg.: Plus ultra. Die Welt der Neuzeit. Festschrift für Alfred Kohler zum 65. Geburtstag. Münster 2008, 289-304.

Bůžek 2009 - Václav Bůžek: Ferdinand von Tirol zwischen Prag und Innsbruck. Der Adel aus den böhmischen Ländern auf dem Weg zu den Höfen der ersten Habsburger. Wien-Köln-Weimar 2009.

Camesina 1872 - Albert Camesina: Die alte Peterskirche zu Wien. Berichte und Mittheilungen des AlterthumsVereines zu Wien XII. 1872, 1-26.

Chmelarz 1886 - Eduard Chmelarz: Die Ehrenpforte des Kaisers Maximilian I. JKSAK IV. 1886, 289-319.

Conti 1589 - Natale Conti: Delle historie de' suoi tempi. Venezia 1589.

Cornova 1802 - Ignaz Cornova Hrsg.: Beschreibung des feyerlichen Einzugs Kaiser Ferdinands I. in die Hauptstadt Prag den 8. November 1558. Prag 1802.

Coronatus Posonii Kat. - Pálffy Géza - Soltész Ferenc Gábor - Tóth Csaba: Coronatus Posonii... Bratislavské korunovačné medaily a žetóny (1563-1830) / A pozsonyi magyar uralkodókoronázások érmei (1563-1830). Spoločná výstava Slovenského národného múzeaHistorického múzea a Mad’arského národného múzea
/ A Szlovák Nemzeti Múzeum - Történeti Múzeum és a Magyar Nemzeti Múzeum közös kiállítása. Bratislavský hrad / Pozsony, Vár. 2014. július 10.2015. január 18. Pozsony-Budapest 2014.

Csuk 1999 - Sieglinde Csuk: Studien zum Grabmal des Grafen Niklas Graf zu Salm †1530, unter besonderer Berücksichtigung der Reliefs. Wien 1999.

Czeike 1959-1960 - Felix Czeike: Hermes Schallauczer. Jahrbuch des Vereines für Geschichte der Stadt Wien 15/16. 1959/60, 70-81.

DaCosta Kaufmann 1978 - Thomas DaCosta Kaufmann: Variations on the Imperial Theme. Studies in Ceremonial Art, and Collecting in the Age of Maximilian II and Rudolf II. (Garland Series, Outstanding Dissertations in the Fine Arts) New York-London 1978.

Deutschmann 1975 - Agathe Deutschmann: Das Augustiner Chorherrenstift St. Dorothea in Wien, seine kulturgeschichtliche Bedeutung für den Niederösterreichischen Raum. Wien 1975.

D. Diemer 2004 - Dorothea Diemer: Kaiser Maximilians Kenotaph in der Innsbrucker Hofkirche - seine Vorgeschichte, seine Entstehung und seine Künstler. In: D. Diemer-Haidacher 2004, 32-64.

D. Diemer-P. Diemer 1995 - Dorothea und Peter Diemer: Das Antiquarium Herzog Albrechts V. von Bayern. Schicksale einer fürstlichen Antikensammlung der Spätrenaissance. Zeitschrift für Kunstgeschichte 58 . 1995, 55-104.

D. Diemer-Haidacher 2004 - Dorothea Diemer - Christoph Haidacher: Maximilian I. Der Kenothaph in der Hofkirche zu Innsbruck. Mit Beiträgen von Ursula Bader-Wieslauer und Karl Wieslauer, Johannes Stephan Schlögl, Sigrid Antretter und Birgit Pichler, Josef Niederbacher. Hrsg. vom Kuratorium des Hofkirche-Erhaltungsfonds. Innsbruck-Wien 2004.

Dmitrieva-Einhorn 2002 - Marina Dmitrieva-Einhorn: Ephemeral Ceremonial Architecture in Prague, Vienna and Cracow in the Sixteenth and Early Seventeenth Centuries. In: J. R. Mulryne - Elizabeth Goldring eds.: Court Festivals of the European Renaissance. Art, Politics and Performance. Aldershot 2002, 363-390.

Doede 1958 - Werner Doede: Schön schreiben, eine Kunst. Johann Neudörffer und seine Schule im 16. und 17. Jahrhundert. München 1958.

Dominkovits-Pálffy 2010 - Dominkovits Péter - Pálffy Géza: Küzdelem az országos és regionális hatalomért. A Nádasdy-család, a magyar arisztokrácia és a Nyugat-Dunántúl nemesi társadalma a 16-17. században. Századok, 144. 2010, 769-792., 1085-1120.

Dressler 1973 - Helga Dressler: Alexander Colin. Karlsruhe 1973.

Dürer és kortársai Kat. - Bodnár Szilvia szerk.: Dürer és kortársai. Müvészóriások óriásmetszetei. I. Miksa császár diadala. Szépművészeti Múzeum, Budapest, 2005. július 1. - október 9. Budapest 2005.

Egg 1974 - Erich Egg: Die Hofkirche in Innsbruck. Das Grabdenkmal Kaiser Maximilians I. und die Silberne Kapelle. Innsbruck-Wien-München 1974.

Endrődi 2000 - Endrődi Gábor: Szent István I. Miksa császár síremlékén. In: Történelem - kép Kat., 196-219.

Farbaky 2003 - Farbaky Péter: Pietro Ferrabosco in Ungheria e nell'impero absburgico. Arte Lombarda 139. 2003, 127-134. 
Fazekas 2008 - Fazekas István: Magyar javaslatok a konstantinápolyi követ személyére 1572-ből. In: Krász Lilla - Oborni Teréz szerk.: Redite ad cor. Tanulmányok Sahin-Tóth Péter emlékére. Budapest 2008, 211-220.

Fazekas 2012 - Fazekas István: A Magyar Udvari Kancellária (1527-1867) és az Erdélyi Udvari Kancellária (1695-1867) története. In: Ujváry Gábor szerk.: A bécsi magyar nagykövetségi épület. Hivatal- és művészettörténeti tanulmányok. Bécs 2012, 49-65.

Feil 1853 - Joseph Feil: Kaiser Ferdinand's I. Einzug in Wien. 14. April 1558. Sylvester-Spende für Freunde zum neuen Jahre 1853. Wien 1853.

Fidler 1987 - Peter Fidler: Die Hofkirche in Innsbruck. Das Kunstwerk als Ergebnis eines politischen Kampfes. ÖZKD 41. 1987, 77-88.

Fontaine Verwey 1976 - Herman de la Fontaine Verwey: Pieter Coecke van Aelst and the publication of Serlio's book on architecture. Quaerendo 6/2. 1976, 167-194.

Galavics 1986 - Galavics Géza: Kössünk kardot az pogány ellen. Török háborúk és képzőmúvészet. Budapest 1986.

Galavics 1987 - Galavics Géza: A magyar királyi udvar és a késő reneszánsz képzőművészet. In: Magyar reneszánsz udvari kultúra, 228-248.

Geschichte der bildenden Kunst in Österreich 3. - Artur Rosenauer Hrsg.: Spätmittelalter und Renaissance. (Geschichte der bildenden Kunst in Österreich, 3.) München-Berlin-London-New York 2003.

Gulyás 2012 - Gulyás Borbála: A török elleni harc megjelenítése a Habsburgok udvari ünnepségein a 16. században. In: Ács Pál - Székely Júlia szerk.: Identitás és kultúra a török hódoltság korában. Budapest 2012, 249-264.

Gulyás 2013a - Gulyás Borbála: Egy elfeledett armális a 16. század második feléből. Gersei Pethő János címerbővítő oklevele (1572). AH XXXIX. 2013/1. (Boreczky Anna - Szakács Béla Zsolt szerk.: Liber decorum. Wehli Tünde köszöntése, I.), 61-66.

Gulyás 2013b - Gulyás Borbála: Bocskay György kalligráfus oklevelei a Habsburg házassági diplomácia szolgálatában. AH XXXIX. 2013/Supplementum (Farbaky Péter - Jernyei Kiss János szerk.: Tanulmányok Kelényi György tiszteletére.), 54-58.

Gulyás 2014 - Gulyás, Borbála: Triumphal Arches in the Court Festivals under the New Holy Roman Emperor, Habsburg Ferdinand I. In: R. Mulryne - K. de Jonge with R. Morris eds.: Occasions of State. Early Modern European Festivals and the Negotiation of Power. Aldershot 2014 (megjelenés alatt).

Gyulai 2012 - Gyulai Éva: Von Sachen gros, von Angsicht klein. Zsámboky János verse Pozsonyról a Habsburg Miksa koronázásáról készült metszeten, 1563/1566. Publicationes Universitatis Miskolcinensis, Sectio Philosophica XVII. 2012, 125-151.

Haidacher 2004 - Christoph Haidacher: Maximilians Leben und Taten in 24 Bildern. Die Marmorreliefs am Grabdenkmal des Kaisers. In: D. Diemer-Haidacher 2004, 81-89.

Helmreich 1567 - Andreas Helmreich: Kunstbüchlein, wie man auf marmelstain, kupfer, messing, zihn, stahl, eisen, harnisch und waffen etc. etzen und künstlich vergülten soll. Leipzig 1567.
Holzmair 1961 - Eduard Holzmair: Das wiedergefundene Inventar der Münzsammlung Ferdinands I. Numismatische Zeitschrift 79. 1961, 79-89.

Holzschuh-Hofer 2007 - Renate Holzschuh-Hofer: Die Wiener Hofburg im 16. Jahrhundert. Festungsresidenz Ferdinands I. ÖZKD 61. 2007, 307-325.

Holzschuh-Hofer 2008 - Renate Holzschuh-Hofer: Die Renaissancezeitliche Hofburg und das Schweizertor mit seiner Programmatik im Lichte der neuen Erkentnisse durch die Bauforschung. ÖZKD 62. 2008, 643-660.

Holzschuh-Hofer 2010a - Renate Holzschuh-Hofer: Radikal elitär oder schlicht bescheiden? Zur Ikonologie der Wiener Hofburg im 16. Jahrhundert unter Ferdinand I. In: Werner Parravicini - Jörg Wettlaufer Hrsg.: Vorbild-Austausch-Konkurrenz. Höfe und Residenzen in den gegenseitigen Wahrnehmung. 11. Symposium der Residenzen-Kommission der Akademie der Wissenschaften Göttingen. Ostfildern 2010, 257-273.

Holzschuh-Hofer 2010b - Renate Holzschuh-Hofer: Feuereisen im Dienst politischer Propaganda von Burgund bis Habsburg. Zur Entwicklung der Symbolik des Ordens vom Goldenen Vlies von Herzog Philipp dem Guten bis Kaiser Ferdinand I. RIHA Journal 0006, 16 August 2010. (http://www.riha-journal.org/ articles/2010/holzschuh-hofer-feuereisen-im-dienstpolitischer-propaganda, letöltés ideje: 2014. júl. 16.)

Horváth 1838 - Horváth Mihály: Gróf Nádasdy Tamás élete, némi tekintettel korára. Buda 1838.

Ilg 1889 - Albert Ilg: Francesco Terzio, der Hofmaler Erzherzog Ferdinands von Tirol. JKSAK IX. 1889, 235-374.

Jankovich Miklós gyűjteményei Kat. - Mikó Árpád szerk.: Jankovich Miklós (1772-1846) gyüjteményei. Kiállítás a Magyar Nemzeti Galériában 2002. november 28 2003. február 16. (A Magyar Nemzeti Galéria kiadványai, 2002/1) Budapest 2002.

Jansen 1982 - Dirk Jacob Jansen: Jacopo Strada (1515-1588). Antiquario della Sacra Cesarea Maestà. In: Leids Kunsthistorisch Jaarboek 1. 1982 (Rudolf II and his court), 57-69.

Jansen 1992 - Dirk Jacob Jansen: The Instruments of Patronage. Jacopo Strada at the Court of Maximilian II. A Case-Study. In: Friedrich Edelmayer - Alfred Kohler Hrsg.: Kaiser Maximilian II. Kultur und Politik im 16. Jahrhundert. (Wiener Beiträge zur Geschichte der Neuzeit, 19) Wien-München 1992, 182-202.

Jonge 2004 - Krista de Jonge: L'édition de la traduction allemande du Livre IV par Jacob Rechlinger chez Pieter Coecke van Aelst à Anvers en 1542 [1543]. In: Sylvie Deswarte-Rosa ed.: Sebastiano Serlio a Lyon. Architecture et imprimerie. Vol. 1. Le traité d'architecture de Sebastiano Serlio. Lyon 2004, 278-279.

Kaiser Ferdinand I. Kat. - Wilfried Seipel Hrsg.: Kaiser Ferdinand I. 1503-1564. Das Werden der Habsburgermonarchie. KHM 15. April bis 31. August 2003. WienMilano 2003.

Kapossy 1956 - Kapossy János (Bánrévi György kiad.): Müvészettörténeti regeszták a királyi határozatokból és rendeletekből. XVI. század. I-III. MÉ V. 1956, 47-53., 190-197., 318-330.

Kayser 1979 - Werner Kayser: Melchior Lorich's Ehrenpforten und Weinbrunnen zum Einzug Maximilians II. in 
Wien, insbesondere die Ehrenpforte beim Waaghaus. Philobiblon 23. 1979, 279-295.

Károlyi 1881 - Károlyi Árpád: Forgách Ferencz, a történetiró Antwerpenben. Történelmi Tár V. 1881, 783-784.

Kieslinger 1959 - Alois Kieslinger: Das Marmorportal der Bürgerstube im Niederösterreichischen Landhause zu Wien. Monatsblatt des Vereines für Landeskunde von Niederösterreich und Wien (Unsere Heimat) 30. 1959, 93-100.

Kieslinger 1963 - Alois Kieslinger: Die älteste Steinätzung. Alte und moderne Kunst 8. Heft 69. 1963, 36-39.

Kieslinger 1965a - Alois Kieslinger: Klosterneuburger Steinätzungen. Jahrbuch des Stiftes Klosterneuburg N. F. 5. 1965, 185-195.

Kieslinger 1965b - Alois Kieslinger: Hans Ostermair und Sixtus Löblein, zwei Landshuter Steinätzkünstler des 16. Jahrhunderts. Verhandlungen des Historischen Vereins für Niederbayern 91. 1965, 83-123.

Kiss 2004 - Kiss Farkas Gábor: A Ragyogó Mágus, avagy a Balassák az udvari ünnepélyeken. In: Uő. szerk: Balassi Bálint és a reneszánsz kultúra. (Traditio Renovata, 1) Budapest 2004, 89-116.

Kloos 1992 - Rudolf M. Kloos: Einführung in die Epigraphik des Mittelalters und der frühen Neuzeit. (Die Kunstwissenschaft) Darmstadt 1992. ${ }^{2}$

Kohn 1998 - Renate Kohn: Wiener Inschriftensammler vom 17. bis zum beginnenden 19. Jahrhundert. (Forschungen und Beiträge zur Wiener Stadtgeschichte, 32.) Wien 1998.

Komáromy 1911 - Komáromy András kiad.: Magyar levelek a XVI. századból. Kilencedik közlemény. Tizedik közlemény. Befejező közlemény. Történelmi Tár, Ú. f. XII. 1911, 89-113., 443-477., 537-564.

Koppány 1984 - Koppány Tibor: Francisco da Pozzo „architectus regius" és köre (Adatok a magyarországi városépítés XVI. századi történetéhez). Müemlékvédelem XXVIII. 1984, 1-6.

Koppány 1987 - Koppány Tibor: Nádasdy Tamás udvara és az építészet. In: Magyar reneszánsz udvari kultúra, 217-227.

Kovachich 1798 - Martinus Georgius Kovachich: Scriptores rerum Hungaricarum minores, I. Buda 1798.

Kratochwill 1965 - Max Kratochwill: Wolfgang Lazius. Wiener Geschichtsblätter 20. (80.) 1965, 449-452.

Kreyczi 1887 - Franz Kreyczi Hrsg.: Urkunden und Regesten aus dem K. u. K. Reichs-Finanz-Archiv (2). JKSAK V. 1887, XXV-CICI.

Krug 2006 - Wolfgang Krug: Die historischen Räume im Niederösterreichischen Landhaus und ihre Ausstattung. In: Anton Eggendorfer Hrsg.: Altes Landhaus. Vom Sitz der niederösterreichischen Stände zum Veranstaltungszentrum. (Katalog des Niederösterreichischen Landesmuseums, N. F. 467.) Wien 2006, 162-217.

Kugler 2003 - Georg Kugler: Kunst und Geschichte im Leben Ferdinands I. In: Kaiser Ferdinand I. Kat., 201-213.

Kühnel 1956 - Harry Kühnel: Forschungsergebnisse zur Geschichte der Wiener Hofburg im 16. Jahrhundert. Anzeiger der Österreichischen Akademie der Wissenschaften, Philosophische-Historische Klasse 93. 1956, 255-271.

Laubach 2010 - Ernst Laubach: Der Reichsvizekanzler Georg Sigmund Seld im Dienst der Kaiser Karl V. und
Ferdinand I. (Schriften des Vereins für Reformationsgeschichte, 212) Heidelberg 2010.

Lazius 1546 - Wolfgang Lazius: Vienna Austriae. Rerum Viennensium Commentarij in Quatuor Libros distincti... Basileae 1546.

Lazius 1551 - Wolfgang Lazius: Commentariorum Rei publicae Romanae illius, in exteris provinciis, bello acquisitis, constitutae, libri XII. Basileae (1551).

Lazius 1558 - Wolfgang Lazius: Commentariorum vetustorum numismatum maximi scilicet operis et IV sectionibus multarum rerum publicarum per Asiam, Aphricam et Europam antiquitatis Historiam (...) comprehendentis Specimen... Viennae 1558.

Lazius 1560 - Wolfgang Lazius: Exempla aliquot S. vetustatis Rom. in saxis quibusdam, opera (...) Hermetis Schallauczeri (...), hic Viennae erutis, Una cum interpretatione Wolfgangi Lazii... Viennae 1560.

Lazius 1563 - Wolfgang Lazius: Periphrasis solenniorum, atque arcuum triumphalium... In: Epitome solenniorum, quæ in auspicatum adventum (...) Maximiliani, Bohemiæ Regis et Archiducis Austriæ etc. una cum quatuor arcuum triumphalium constitutione, eorumque explicatione... Viennae 1563, AIVr-CIv

Lhotsky 1941-1945 - Alphons Lhotsky: Die Geschichte der Sammlungen. Erste Hälfte. Von den Anfängen bis zum Tode Kaiser Karls VI. 1740. (Festschrift des Kunsthistorischen Museums zur Feier des fünfzigjährigen Beständes, 2/1) Wien 1941-1945.

Lietzmann 1987 - Hilda Lietzmann: Das Neugebäude in Wien. Sultan Süleymans Zelt - Kaiser Maximilians II. Lustschloß. Ein Beitrag zur Kunst- und Kulturgeschichte der zweiten Hälfte des sechzehnten Jahrhunderts. München-Berlin 1987.

Louthan 1997 - Howard Louthan: The Quest for Compromise. Peacemakers in Counter-Reformation Vienna. (Cambridge Studies in Early Modern History) Cambridge 1997.

Lővei 2001 - Lővei, Pál: „Virtus, es, marmor, scripta”. Red Marble and Bronze Letters. AHA 42. 2001, 47-55.

Lóvei 2004 - Lővei Pál: „Virtus, es, marmor, scripta”. Vörös márvány és bronzbetű. In: Bodnár Szilvia - Jávor Anna - Lővei Pál - Pataki Gábor - Sümegi György - Szilágyi András szerk.: Maradandóság és változás. Müvészettörténeti konferencia. Ráckeve, 2000. Budapest 2004, 53-71.

Ludiková 2006 - Zuzana Ludiková: Epitaf miestodržitel'a Alexeja Thurza od sochára Loya Heringa v Levoči. Acta Musaei Scepusiensis 2006, 173-188.

Ludiková 2009 - Zuzana Ludiková: Zsámboky János röplapja Miksa magyar királlyá koronázásáról. Századok 143. 2009, 975-980.

Magyar reneszánsz udvari kultúra - R. Várkonyi Ágnes - Székely Júlia szerk.: Magyar reneszánsz udvari kultúra. Budapest 1987.

Mattioli 1559 - Pierandrea Mattioli: Le solenni pompe, i superbi et gloriosi apparati, i trionfi, i fuocchi, et gli altri splendidi et diletteuoli spettacoli fatti alla uenuta dell' inuittisimo imperatore Ferdinando primo (...) nella Real città di Praga l'ottauo giorno di Nouembre M. D. LVIII. Praga 1559.

Meiss 1976 - Millard Meiss: Alphabetical Treatises in the Renaissance. In: Uő: The Painter's Choice. Problems 
in the Interpretation of Renaissance Art. New YorkHagerstown-San Francisco-London 1976, 176-186.

Mikó 2005a - Mikó Árpád: Stílus és felirat. Kőbe vésett, klasszikus- és korai humanista kapitálissal írott feliratok a Mátyás- és Jagelló-kori Magyarországon. MÉ LIV. 2005, 205-244.

Mikó 2005b - Mikó Árpád: Késő reneszánsz és kora barokk síremlékek a Magyar Királyság területén (1540-1690). In: G. Etényi Nóra - Horn Ildikó szerk.: Idővel paloták... Magyar udvari kultúra a 16-17. században. Budapest 2005, 625-660.

Mikó 2013 - Mikó Árpád: Pietro Ferrabosco számadása a Miksa magyar királlyá koronázására épített pozsonyi diadalkapuról (1563). MÉ LXII. 2013, 323-328.

Mitchell 1979 - Bonner Mitchell: Italian Civic Pageantry in the High Renaissance. A Descriptive Bibliography of Triumphal Entries and Selected Other Festivals for State Occasions. (Biblioteca di bibliografia Italiana, LXXXIX) Firenze 1979.

Morison 1972 - Stanley Morison: Politics and Script. Aspects of authority and freedom in the development of Graeco-Latin script from the sixth century B.C. to the twentieth century A.D. (The Lyell Lectures 1957) Oxford 1972.

Müller 1982 - Jan-Dirk Müller: Gedechtnus. Literatur und Hofgesellschaft um Maximilian I. München 1982.

Nimmrichter 2006 - Johann Nimmrichter: Bericht und Massnahmenkatalog (Vorschlag). Bundesdenkmalamt, Landeskonservatorat Burgenland, Bécs, 2885/VI.: 3/2006.

ÖKT LVI. - Judit Schöbel et al.: ÖKT LVI. Die Kunstdenkmäler des politischen Bezirkes Oberpullendorf. Horn 2005.

Panvinio 1557a - Onuphrio Panvinio: Fasti et Triumphi Rom. a Romulo Rege usque ad Carolum V. (...) ex Musaeo Iacobi Stradæ Mantuani, ciuis Romani, Antiquarij. Venetiis 1557.

Panvinio 1557b - Onuphrio Panvinio: Epitome Pontificum Romanorum... Venetiis 1557.

Panvinio 1558 - Onuphrio Panvinio: Fastorum Libri V a Romulo Rege usque ad Imp. Caesarem Carolum V... Venetiis 1558.

Pálffy 1999 - Pálffy Géza: Nádasdy Tamás, a Dunántúl főkapitánya (1542-1546 és 1548-1552). In: Söptei István szerk.: Nádasdy Tamás (1498-1562). Tudományos emlékülés: Sárvár, 1998. szeptember 10-11. (Nádasdy Ferenc Múzeum Kiadványai, 3.) Sárvár 1999, 29-54.

Pálffy 2005 - Pálffy Géza: Magyar címerek, zászlók és felségjelvények a Habsburgok dinasztikus-hatalmi reprezentációjában a 16. században. Történelmi Szemle XLVII. 2005, 241-275.

Pálffy 2010 - Pálffy Géza: A Magyar Királyság és a Habsburg Monarchia a 16. században. (História Könyvtár, Monográfiák, 27) Budapest 2010.

Pálffy 2014 - Pálffy Géza: Hatalmi és művészeti reprezentáció: magyar uralkodókoronázások a kora újkori Pozsonyban. In: Coronatus Posonii Kat., 21-31.

Perger-Brauneis 1977 - Richard Perger - Walther Brauneis: Die mittelalterlichen Kirchen und Klöster Wiens. (Wiener Geschichtsbücher, 19/20) Wien-Hamburg 1977.

Pfaffenbichler 1992 - Matthias Pfaffenbichler: Das Turnier als Instrument der Habsburgischen Politik. Waffen- und Kostümkunde 1992, 13-36.
Philipp 2011 - Marion Philipp: Ehrenpforten für Kaiser Karl V. Festdekorationen als Medien politischer Kommunikation. (Kunstgeschichte, 90) Berlin 2011.

Pischl-Schlögl 2002 - Karl Pischl - Johannes Stephan Schlögl: Restaurierung des Kenotaphs Kaiser Maximilian I. in der Hofkirche zu Innsbruck. Innsbruck 2002.

Podhradczky 1834 - Podhradczky József: Nádasdy Tamás élete leírásához töredék. Tudományos Gyüjtemény XIII. 1834, VII., 36-55.

Polleroß 1998 - Friedrich Polleroß: Tradition und Recreation. Die Residenzen der österreichischen Habsburger in der Frühen Neuzeit (1490-1780). Maiestas 6. 1998, 91-148. Polleroß 2006 - Friedrich Polleroß: Romanitas in der habsburgischen Repräsentation von Karl V. bis Maximilian II. In: Richard Bösel - Grete Klingenstein - Alexander Koller Hrsg.: Kaiserhof-Papsthof (16-18. Jahrhundert). Wien 2006, 207-223.

Primisser 1812 - Gottfried Primisser: Denkmaehler der Kunst und das Alterthums in der Kirche zum Heiligen Kreuz zu Innsbruck. Innsbruck 1812.

Rasmussen 2014 - Mikael Bøgh Rasmussen: Vienna Redecorated in Classical Guise. The Entry of Maximilian II as King of the Romans in 1563. Elhangzott az ESF PALATIUM Programme és a Society for European Festivals Research Making Space for Festival. 1400-1700. Interactions of Architecture and Performance in Late Medieval and Early Modern Festivals c. konferenciáján (Velence 2013.)

Ritoókné 1994 - Ritoókné Szalay Ágnes: A római föliratok gyưjtői Pannóniában. In: Mikó Árpád - Takács Imre szerk.: Pannonia Regia. Múvészet a Dunántúlon. 1000-1541. Magyar Nemzeti Galéria, 1994. október 1995. február. (A Magyar Nemzeti Galéria kiadványai, 1994/3) Budapest 1994, 318-325.

Rotis 1558 - Petrus a Rotis: Triumphi, quo D. Ferdinandus I. Ro. Imperator (...) Viennae à suis exceptus est, Descriptio. Viennae 1558.

Rudolph 2011 - Harriet Rudolph: Das Reich als Ereignis. Formen und Funktionen der Herrschaftsinszenierung bei Kaisereinzügen (1558-1618). (Norm und Struktur, 38) Köln-Weimar-Wien 2011.

Ruggenthaler 2006 - P. Oliver Ruggenthaler OFM: Das Maximilian-Mausoleum in der Innsbrucker Hofkirche nach Quellen des Archivs der Tiroler Franziskanerprovinz. Tiroler Heimat 70. 2006, 85-97.

Sacken 1853 - Eduard Freiherr von Sacken: Der Lazenhof und die daselbst aufgefundenen Inschriften. Österreichische Blätter für Literatur und Kunst (Beilage zur Wiener Zeitung) 15. 1853. ápr. 11. 89-90.

Schauerte 2001 - Thomas Ulrich Schauerte: Die Ehrenpforte für Kaiser Maximilian I. Dürer und Altdorfer im Dienst des Herrschers. München-Berlin 2001.

Scheicher 1979 - Elisabeth Scheicher: Die Kunst- und Wunderkammern der Habsburger. Wien-München-Zürich-Innsbruck 1979.

Scheicher 1983 - Elisabeth Scheicher: Die Imagines gentis Austriacae des Francesco Terzio. Jahrbuch der kunsthistorischen Sammlungen in Wien 79. 1983, 43-92.

Scheicher 1986 - Elisabeth Scheicher: Das Grabmal Kaiser Maximilians I. in der Hofkirche. In: Johanna Felmayer - Karl und Ricarda Oettinger - Elisabeth Schleicher: ÖKT XLVII. Die Kunstdenkmäler der Stadt Innsbruck. Die Hofbauten. Wien 1986, 355-426. 
Scheicher 1999 - Elisabeth Scheicher: Kaiser Maximilian plant sein Grabmal. Jahrbuch des Kunsthistorischen Museums Wien 1. (93.) 1999, 81-117.

Schlager 1850 - Johann Evangelist Schlager: Materialen zur österreichischen Kunstgeschichte. Mit einer Uebersichts-Tabelle und alphabetischgeordnetem OriginalTexte von etwa vierthalbhundert Namen. In: Archiv für Kunde österreichischer Geschichts-Quellen V. Wien 1850, 661-780.

Schlögl 2004 - Johannes Stephan Schlögl: Zur Restaurierung und Konservierung der Reliefs und Steinbauteile am Kenotaph Kaiser Maximilian I. In: D. DiemerHaidacher 2004, 189-211.

Schönherr 1884 - David Ritter von Schönherr Hrsg.: Urkunden und Regesten aus dem k. k. StatthaltereiArchiv in Innsbruck (1). JKSAK II. 1884, I-CLXXII.

Schönherr 1890a - David Ritter von Schönherr: Geschichte des Grabmals Kaisers Maximilian I. und der Hofkirche zu Innsbruck. JKSAK XI. 1890, 140-268.

Schönherr 1890b - David Ritter von Schönherr Hrsg.: Urkunden und Regesten aus dem k. k. StatthaltereiArchiv in Innsbruck (2). JKSAK XI. 1890, LXXXIVCCXLI.

Schönherr 1893 - David Ritter von Schönherr Hrsg.: Urkunden und Regesten aus dem k. k. StatthaltereiArchiv in Innsbruck (3). JKSAK XIV. 1893, LXXICCXIII.

Seelig 2008 - Lorenz Seelig: Die Münchner Kunstkammer. In: Elke Bujok - Dorothea Diemer - Peter Diemer Lorenz Seelig - Peter Volk - Brigitte Volk-Knüttel - Friederike Wappenschmidt, Vorg. von Willibald Sauerländer: Die Münchner Kunstkammer. Band 3. Aufsätze und Anhänge. (Bayerische Akademie der Wissenschaften Philosophisch-Historische Klasse Abhandlungen, N. F. 129) München 2008, 1-114.

Seidl 2003 - Katharina Seidl: Das Maximiliansgrab. In: Kaiser Ferdinand I. Kat., 243-247.

Serlio 1537 - Sebastiano Serlio: Regole generali di architetura sopra le cinque maniere de gli edifici... Venetia 1537.

Serlio 1542 - (Sebastiano Serlio, ed. Pieter Coecke van Aelst:) Die gemaynen Reglen von der Architectur uber die funf Manieren der Gebeu... Antwerpen 1542.

Silver 1990 - Larry Silver: Paper Pageants. The Triumphs of Emperor Maximilian I. In: Barbara Wisch - Susan Scott Munshower eds.: Art and Pageantry. Vol. 1: Triumphal Celebrations and the Rituals of Statecraft. Pennsylvania 1990, 293-331.

Soltész-Tóth 2014 - Soltész Ferenc Gábor-Tóth Csaba: Uralkodói reprezentáció a magyar királykoronázások érmein és zsetonjain. In: Coronatus Posonii Kat., 41-49.

Sperling 1989 - Christine M. Sperling: Leon Battista Alberti's Inscriptions on the Holy Sepulchre in the Cappella Rucellai, San Pancrazio, Florence. Journal of the Warburg and Courtauld Institutes 52. 1989, 221-228.

Stainhofer 1566 - Caspar Stainhofer: Gründliche und khurze Beschreibung des alten und jungen Zugs... Wienn 1566.

Stenhouse 2005 - William Stenhouse: Reading Inscriptions and Writing Ancient History. Historical Scholarship in the Late Renaissance. (Bulletin of the Institute of Classical Studies, Supplement 86) London 2005.

Stenhouse 2012 - William Stenhouse: Panvinio and descriptio. Renditions of History and Antiquity in the Late
Renaissance. Papers of the British School at Rome 80. 2012, 233-256.

Stöger 1989 - Josef Stöger: Die Inschriften der Krypta von Lockenhaus. Burgenländische Heimatblätter 51. 1989, 52-72.

Strong 1984 - Roy Strong: Art and Power. Renaissance Festivals. 1450-1650. Woodbridge 1984.

Szentesi 2010 - Szentesi Edit: First Meeting of the Betrothed Pair. A Habsburgian Iconographic Type. In: Livia Varga - László Beke - Anna Jávor - Pál Lővei - Imre Takács eds.: BONUM UT PULCHRUM. Essays in Art History in Honour of Ernő Marosi on His Seventieth Birthday. Budapest 2010, 381-404.

Szücs 2012 - Veronika Szücs: Das Wiener Neugebäude und die Kunst der Irenik am Hofe Maximilians II. AHA 53. 2012, 45-136.

Thomas 1993 - Christiane Thomas: Wien als Residenz unter Kaiser Ferdinand I. Studien zur Wiener Geschichte 49. 1993, 101-117.

Toma 2010 - Toma Katalin: Gróf Nádasdy III. Ferenc mecénási működésének társadalmi, anyagi és szellemi háttere. Századok 144. 2010, 853-872.

Tóth 1966-1970 - Tóth Melinda: A sárvári vár építéstörténete. Savaria. A Vas Megyei Múzeumok Értesítője 4. 1966-1970, 193-286.

Történelem - kép Kat. - Mikó Árpád - Sinkó Katalin szerk.: Történelem - kép. Szemelvények múlt és művészet kapcsolatából Magyarországon. Kiállítás a Magyar Nemzeti Galériában 2000. március 17 - szeptember 24. Budapest 2000.

Trautmann 1869 - Franz Trautmann: Kunst und Kunstgewerbe vom frühesten Mittelalter bis Ende des achtzehnten Jahrhunderts. Ein Hand- und Nachschlagebuch zur leichten Orientirung in Fächern und Schulen, Meistern, Nachahmungen, Mustern, Technik, Zeichen und Literatur. Nördlingen 1869.

Trenkler 1978 - Ernst Trenkler: Wolfgang Lazius, Humanist und Büchersammler. Biblos 27. 1978, 186-203.

Viskolcz 2010 - Viskolcz Noémi: Nádasdy III. Ferenc gyűjteményei. Századok 144. 2010, 873-893.

Vocelka 1978 - Karl Vocelka: Die Wiener Feste der frühen Neuzeit aus waffenkundlicher Sicht. Jahrbuch des Vereins für Geschichte der Stadt Wien 34. 1978, 133-148.

Vogel 1933 - Walter Vogel: Der Reichsvizekanzler Georg Sigmund Seld, sein Leben und Wirken. Leipzig 1933.

Voltelini 1890 - Hans von Voltelini Hrsg.: Urkunden und Regesten aus dem K. u. K. Haus-, Hof- und Staats-Archiv in Wien (1). JKSAK XI. 1890, I-LXXXIII.

Voltelini 1898 - Hans von Voltelini Hrsg.: Urkunden und Regesten aus dem K. u. K. Haus-, Hof- und Staats-Archiv in Wien (3). JKSAK XIX. 1898, I-CXVI.

Wallner 1912 - Bertha Antonia Wallner: Musikalische Denkmäler der Steinätzkunst des 16. u. 17. Jahrhunderts nebst Beiträgen zur Musikpflege dieser Zeit. München 1912.

Wardrop 1952 - James Wardrop: Civis Romanvs svm. Giovanbattista Palatino and His Circle. Signature N. S. 14. 1952, 3-38.

Wastler 1887 - Joseph Wastler: Die Technik der Steinätzung und deren Künstler in der Steiermark im 16. und 17. Jahrhundert. Mittheilungen der K. K. Central-Commission zur Erforschung und Erhaltung der Kunstund Historischen Denkmale N. F. XIII. 1887, I-VI. 
Watanabe O'Kelly 1999 - Helen Watanabe O'Kelly: Entries, fireworks and religious festivals in the Empire. In: Pierre Béhar - Helen Watanabe O'Kelly eds: Spectacvlvm Europævm. Theatre and Spectacle in Europe. Histoire du spectacle in Europe (1580-1750). (Wolfenbütteler Arbeiten zur Barockforschung, 31.) Wiesbaden 1999, 721-741.

Werke für die Ewigkeit Kat. - Wilfried Seipel Hrsg.: Werke für die Ewigkeit. Kaiser Maximilian I. und Erzherzog Ferdinand II. KHM Sammlungen Schloss Ambras 6. Juli bis 31. Oktober 2002. Wien 2002

Widmoser 1972 - Eduard Widmoser: Was kosteten das Grabmal Maximilians und die Hofkirche? In: Franz Heinz Hye Hrsg.: Festschrift für Karl Schadelbauer zur Vollendung des 70. Lebensjahres. (Veröffentlichungen des Innsbrucker Stadtarchivs, N. F. 3) Innsbruck 1972, 201-204.

Winkler 1980 - Gerhard Winkler: Das Turnierbuch Hans Francolins. Wissenschaftliche Mitteilungen aus dem Niederösterreichischen Landesmuseum 1. 1980, 105-120.
Wir sind Helden Kat. - Wilfried Seipel Hrsg.: Wir sind Helden. Habsburgische Feste in der Renaissance. Schloss Ambras, Innsbruck 10. Juni -31. Oktober 2005. Wien 2005.

Wünsch 1914 - Josef Wünsch: Der Einzug Kaiser Maximilians II. in Wien 1563. Berichte und Mittheilungen des Alterthums-Vereines zu Wien 46. 1914, 11-34.

Zajic 2004 - Andreas Zajic: „Zu ewiger gedächtnis aufgericht." Grabdenkmäler als Quelle für Memoria und Repräsentation von Adel und Bürgertum im Spätmittelalter und in der Frühen Neuzeit. Das Beispiel Niederösterreichs. (Mitteilungen des Instituts für Österreichische Geschichtsforschung, Ergänzungsband 45) Wien-München 2004.

Zimmerl 1953 - Rudolf Zimmerl: Die Inschriften des Burgenlandes. (Die Deutschen Inschriften, 3 Wiener Reihe, 1) Stuttgart 1953.

\section{SEPULCHRAL INSCRIPTIONS IN ANTIQUE SQUARE CAPITALS BY THE CALLIGRAPHER GYÖRGY BOCSKAY REPRESENTATIO ALL'ANTICA AT THE COURT OF FERDINAND I IN VIENNA}

György (George) Bocskay (†1575) was a member of a well-known Hungarian noble family. He was capable to adapt himself to the expectations of the Viennese court of the Habsburg Monarchy to build a significant career at the Hungarian Royal Chancellery as royal court secretary, royal councillor and calligrapher. He decorated various writing model books and charters for the Habsburg rulers as well as several letters of arms for Hungarian noblemen. However it is less known that the calligrapher made sepulchral inscriptions in stone as well applying a new technique of his time, the acid-etching. Emperor Ferdinand I commissioned him to prepare the Square Capitals for the marble cenotaph of Emperor Maximilian I in Innsbruck. Additionally, he used similar letters to inscribe the sepulchral monument of the highest ranking official of the Hungarian Kingdom, the Palatine Tamás Nádasdy and his wife, Orsolya Kanizsay in Léka (Lockenhaus).

After the Treaty of Passau (1552) the claim was established that after Emperor Charles V the member of the Austrian line of the Habsburg dynasty, Ferdinand I could have imperial power. The revival of the antiquity significantly influenced the rebuilding of his main residence, the Hofburg, the development of the Roman lapidaries and collections of antiquities at his court (Hermes Schallauzer, Wolfgang Lazius, Ferdinand I), and the style of festive decorations and artworks all'antica he commissioned during this era.

In 1562 Bocskay dedicated a writing model book to Ferdinand I in order to be commissioned to prepare the inscriptions of the sepulchral monument of Emperor Maximilian I. The manuscript included several writing samples in Square Capitals imitating the epigraphic monuments of the ancient Romans. Later he worked on the acid-etched and gilded inscriptions in Vienna in 1563-1568 according to the archival sources. He pre- pared inscribed marble plates for 24 marble reliefs of the cenotaph representing scenes of the life of Maximilian I as well as 18 plates of the sepulchral inscription on the frieze. The Latin texts were compiled by the vice-chancellor of Ferdinand I, Georg Sigmund Seld.

Bocskay was accommodated in the house of the Nádasdy family in Vienna. He probably equipped a workshop for the process there. He also prepared three more inscribed limestone plates for the sepulchral monument of the already mentioned Tamás Nádasdy and Orsolya Kanizsay. The marble cenotaph was erected in 1566 in the castle of Léka where the Palatine and later his wife were buried. The monument was transferred to the new family crypt of the Augustine monastery of Léka in the $17^{\text {th }}$ century.

GULYÁS Borbála művészettörténész, Magyar Tudományos Akadémia, Bölcsészettudományi Kutatóközpont, Múvészettörténeti Intézet / art historian, Hungarian Academy of Sciences, Research Centre for the Humanities, Institute of Art History. gulyas.borbala@btk.mta.hu

Kulcsszavak: kalligráfia, Bocskay György, síremlékfelirat, I. Miksa császár síremléke (Innsbruck), Nádasdy Tamás nádor és Kanizsay Orsolya síremléke (Léka), I. Ferdinánd, all'antica udvari reprezentáció, Pietro Ferrabosco, Hermes Schallauzer, Wolfgang Lazius, Jacopo Strada, klasszikus antikva kapitális, kőmaratás / Keywords: calligraphy, George Bocskay, sepulchral inscription, sepulchral monument of Emperor Maximilian I. (Innsbruck), sepulchral monument of Palatine Tamás Nádasdy and his wife, Orsolya Kanizsay (Léka), Ferdinand I, representatio all'antica and antiquarianism at the court of Vienna, Pietro Ferrabosco, Hermes Schallauzer, Wolfgang Lazius, Jacopo Strada, Roman Square Capitals, acid-etching 